Louisiana State University

LSU Digital Commons

Faculty Publications

Department of Geology and Geophysics

2-1-2016

\title{
Continental carbonate facies of a Neoproterozoic panglaciation, north-east Svalbard
}

\author{
Ian J. Fairchild \\ University of Birmingham \\ Edward J. Fleming \\ University of Birmingham \\ Huiming Bao \\ Louisiana State University \\ Douglas I. Benn \\ The University Centre in Svalbard \\ Ian Boomer \\ University of Birmingham
}

See next page for additional authors

Follow this and additional works at: https://digitalcommons.Isu.edu/geo_pubs

\section{Recommended Citation}

Fairchild, I., Fleming, E., Bao, H., Benn, D., Boomer, I., Dublyansky, Y., Halverson, G., Hambrey, M., Hendy, C., McMillan, E., Spötl, C., Stevenson, C., \& Wynn, P. (2016). Continental carbonate facies of a Neoproterozoic panglaciation, north-east Svalbard. Sedimentology, 63 (2), 443-497. https://doi.org/10.1111/sed.12252

This Article is brought to you for free and open access by the Department of Geology and Geophysics at LSU Digital Commons. It has been accepted for inclusion in Faculty Publications by an authorized administrator of LSU Digital Commons. For more information, please contact ir@lsu.edu. 


\section{Authors}

Ian J. Fairchild, Edward J. Fleming, Huiming Bao, Douglas I. Benn, lan Boomer, Yuri V. Dublyansky, Galen P. Halverson, Michael J. Hambrey, Chris Hendy, Emily A. McMillan, Christoph Spötl, Carl T.E. Stevenson, and Peter M. Wynn 


\section{Aberystwyth University}

\section{Continental carbonate facies of a Neoproterozoic panglaciation, north-east Svalbard}

Fairchild, Ian J.; Fleming, Edward J.; Bao, Huiming; Benn, Douglas I; Boomer, lan; Dublyansky, Yuri V.; Halverson, Galen P.; Hambrey, Michael; Hendy, Chris; Mcmillan, Emily A.; Spötl, Christoph; Stevenson, Carl T. E.; Wynn, Peter M.

\section{Published in:}

Sedimentology

DOI:

10.1111/sed.12252

\section{Publication date:}

2016

Citation for published version $(A P A)$ :

Fairchild, I. J., Fleming, E. J., Bao, H., Benn, D. I., Boomer, I., Dublyansky, Y. V., Halverson, G. P., Hambrey, M., Hendy, C., Mcmillan, E. A., Spötl, C., Stevenson, C. T. E., \& Wynn, P. M. (2016). Continental carbonate facies of a Neoproterozoic panglaciation, north-east Svalbard. Sedimentology, 63(2), 443-497. https://doi.org/10.1111/sed.12252

\section{Document License}

CC BY-NC

\section{General rights}

Copyright and moral rights for the publications made accessible in the Aberystwyth Research Portal (the Institutional Repository) are retained by the authors and/or other copyright owners and it is a condition of accessing publications that users recognise and abide by the legal requirements associated with these rights. research

- Users may download and print one copy of any publication from the Aberystwyth Research Portal for the purpose of private study or

- You may not further distribute the material or use it for any profit-making activity or commercial gain

- You may freely distribute the URL identifying the publication in the Aberystwyth Research Portal

Take down policy

If you believe that this document breaches copyright please contact us providing details, and we will remove access to the work immediately and investigate your claim.

tel: +44 1970622400

email: is@aber.ac.uk 
Received Date : 04-Dec-2014

Revised Date : 25-Oct-2015

Accepted Date : 28-Oct-2015

Article type : Original Manuscript

\section{Continental carbonate facies of a Neoproterozoic panglaciation, north-east}

\section{Svalbard}

IAN J. FAIRCHILD*, EDWARD J. FLEMING*†‡, HUIMING BAO§, DOUGLAS I. BENN+ף, IAN BOOMER*,

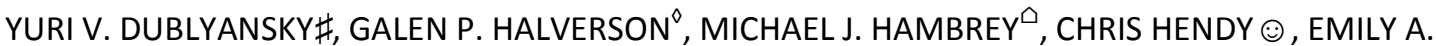
MCMILLAN*, CHRISTOPH SPÖTL\#, CARL T.E. STEVENSON*AND PETER M. WYNN•

*School of Geography, Earth and Environmental Sciences, University of Birmingham B15 2TT, UK. (Email: i.j.fairchild@bham.ac.uk)

†Department of Geology, The University Centre in Svalbard (UNIS), N-9171 Longyearbyen, Norway ‡Present address: CASP, West Building, 181A Huntingdon Road, Cambridge, CB3 ODH, UK

§Department of Geology and Geophysics, E235 Howe-Russell Complex, Louisiana State University, Baton Rouge, LA 70803, USA

ПSchool of Geography and Geosciences, University of St Andrews, St Andrews KY16 8YA, Scotland, UK

৩Department of Earth \& Planetary Sciences/Geotop, 3450 University St. Montreal, Quebec H3A 0E8, Canada

${ }^{\triangle}$ Department of Geography and Earth Sciences, Aberystwyth University, Aberystwyth, Ceredigion SY23 3DB, UK

This is an Accepted Article that has been peer-reviewed and approved for publication in the Sedimentology, but has yet to undergo copy-editing and proof correction. Please cite this article as an "Accepted Article"; doi: 10.1111/sed.12252

This article is protected by copyright. All rights reserved. 
(-) Department of Chemistry, University of Waikato, Private Bag 3105, Hamilton 3240, New Zealand.

\#Institut für Geologie, Leopold-Franzens-Universität Innsbruck, Innrain 52,

A-6020 Innsbruck, Austria

- Lancaster Environment Centre, University of Lancaster, Lancaster LA1 4YQ, UK

\section{Associate Editor - Guy Spence}

\section{Short Title - Continental glacial carbonates}

ABSTRACT

The Marinoan panglaciation (?650 to $635 \mathrm{Ma}$ ) is represented in north-east Svalbard by the 130 to $175 \mathrm{~m}$ thick Wilsonbreen Formation which contains syn-glacial carbonates in its upper $100 \mathrm{~m}$. These sediments are now known to have been deposited under a $\mathrm{CO}_{2}$-rich atmosphere, late in the glaciation, and global climate models facilitate testing of proposed analogues. Precipitated carbonates occur in four of the seven facies associations identified: Fluvial Channel (including stromatolitic and intraclastic limestones in ephemeral stream deposits); Dolomitic Floodplain (dolomite-cemented sand and siltstones, and microbial dolomites); Calcareous Lake Margin (intraclastic dolomite and wave-rippled or aeolian siliciclastic facies); and Calcareous Lake (slumpfolded and locally re-sedimented rhythmic/stromatolitic limestones and dolomites associated with ice-rafted sediment). There is no strong cyclicity, and modern analogues suggest that sudden changes in lake level may exert a strong control on facies geometry. Both calcite and dolomite in stromatolites and rhythmites display either primary or early diagenetic replacive growth. Oxygen isotope values (-12 to $+15 \%$ ovPDB $)$ broadly covary with $\delta^{13} \mathrm{C}$. High $\delta^{13} \mathrm{C}$ values of +3.5 to $+4.5 \%$ o correspond to equilibration with an atmosphere dominated by volcanically degassed $\mathrm{CO}_{2}$ with $\delta^{13} \mathrm{C}$ of -6 to $-7 \%$. Limestones have consistently negative $\delta^{18}$ O values, whilst rhythmic and playa dolomites preserve intermediate compositions, and dolocretes possess slightly negative to strongly positive $\delta^{18} \mathrm{O}$ signatures, reflecting significant evaporation under hyperarid conditions. Inferred This article is protected by copyright. All rights reserved. 
meltwater compositions (-8 to $-15.5 \%$ ) could reflect smaller Rayleigh fractionation related to more limited cooling than in modern polar regions. A common pseudomorph morphology is interpreted as a replacement of ikaite $\left(\mathrm{CaCO}_{3} \mathrm{H}_{2} \mathrm{O}\right)$, which may also have been the precursor for widespread replacive calcite mosaics. Local dolomitization of lacustrine facies is interpreted to reflect microenvironments with fluctuating redox conditions. Although differing in (palaeo)latitude and carbonate abundance, the Wilsonbreen carbonates provide strong parallels with the McMurdo Dry Valleys of Antarctica.

Keywords: Carbon isotopes, Cryogenian, ikaite pseudomorphs, lacustrine, oxygen isotopes, Snowball Earth

\section{INTRODUCTION}

The second of two Neoproterozoic panglaciations, in which ice sheets reached sea-level in the tropics, terminated $635 \mathrm{Myr}$ ago at the base of a transgressive cap carbonate defining the Cryogenian-Ediacaran System boundary (Table 1). Deposits of Cryogenian ice ages are preserved on most continents and are commonly interpreted as glacimarine (Arnaud et al., 2011). However, in north-east Svalbard, the Marinoan-aged, 130 to $175 \mathrm{~m}$ thick Wilsonbreen Formation (Halverson, 2011) uniquely contains non-marine carbonates as well as subglacial tillites (Fig. 1). These evince hyperarid terrestrial environments (Fairchild et al., 1989) and an atmosphere rich in carbon dioxide during glaciation (Bao et al., 2009), the latter conclusion fulfilling a prediction of the Snowball Earth hypothesis (Kirschvink, 1992; Hoffman et al., 1998). Because Wilsonbreen Formation outcrops are restricted to remote icefield nunataks on Spitsbergen (Fig. 2) and coastal eastern Nordaustlandet, they have rarely been visited, and hence current knowledge of the sedimentary architecture has been incomplete. Wilsonbreen Formation carbonates contain the highest carbonate and sulphate $\delta^{18} \mathrm{O}$ values and lowest sulphate $\Delta^{17} \mathrm{O}$ signatures so far discovered in the geological record, features This article is protected by copyright. All rights reserved. 
which evoke one of the most extreme climatic events in Earth history (Bao et al., 2009, Benn et al., 2015). This article characterizes a range of non-marine environments in which the carbonates were precipitated using a combination of field, petrographic and stable isotope evidence, and scrutinizes their analogy to the extreme terrestrial environments of the modern McMurdo Dry Valley region of Antarctica (Fairchild et al., 1989).

The study area in the Svalbard mainland of Spitsbergen (Figs 1 and 2) and the basin continuation to the north-east have long been recognized as classic areas for late Precambrian glaciation (Kulling 1934). The first detailed description of the Wilsonbreen Formation was by Wilson \& Harland (1964), although carbonates were discussed only in terms of its bounding dolomites which serve as stratigraphic markers. A later sedimentological synthesis (Hambrey, 1982; Fairchild \& Hambrey, 1984) showed that evidence of glacial activity was confined to two glacial units in the Polarisbreen Group: the Wilsonbreen Formation, and a newly discovered, thin, older unit in the Elbobreen Formation (Petrovbreen Member also known as E2; Table 1). Several distinctive forms of carbonate occur in association with the glacial deposits. Dolomitic glacial rock flour was first demonstrated in ultra-thin sections (Fairchild, 1983). Subsequent stable isotope studies showed the presence of glacimarine precipitates in the Petrovbreen Member and glacilacustrine deposits in the Wilsonbreen Formation (Fairchild \& Hambrey, 1984; Fairchild \& Spiro, 1987; Fairchild et al., 1989). It was also shown that these carbonates contrast with a distinctive marine transgressive 'cap carbonate' (following Williams, 1979) over the Wilsonbreen Formation. Halverson et al. (2004) provided a much more detailed chemostratigraphic framework for the Polarisbreen Group and postulated that both diamictite units belonged to the same, Marinoan glaciation. However, new chemostratigraphic data led to a reversion to the previous two-fold glaciation interpretation of older literature (Halverson, 2006; Hoffman et al., 2012). No direct geochronological constraints exist on Svalbard, but the low ${ }^{87} \mathrm{Sr} /{ }^{86} \mathrm{Sr}$ values at the base of the Polarisbreen Group correlate well with those associated with the first evidence of Neoproterozoic glaciation elsewhere (Halverson et al., 2010). Also, the transgressive-regressive succession above the Wilsonbreen Formation closely resembles This article is protected by copyright. All rights reserved. 
the basal Ediacaran facies succession globally (Halverson et al., 2004). The end of Marinoan glaciation, and hence the top of the Wilsonbreen Formation is $635 \mathrm{Ma}$ (Rooney et al., 2015 and references therein). Palaeomagnetic constraints suggest that north-east Svalbard lay in the subtropics throughout the Cryogenian (Li et al., 2013) as part of Laurentia, which spanned the equator in the centre of the fragmenting Rodinia supercontinent.

The closely similar stratigraphy in central East Greenland (now officially redesignated as Northeast Greenland; Hambrey \& Spencer, 1987; Moncrieff \& Hambrey, 1990) indicates that it represents a basin continuation (Hambrey, 1983; Knoll et al., 1986; Fairchild \& Hambrey, 1995), subsequently offset to the south by left-lateral strike-slip faulting (Harland, 1997). The distinct Neoproterozoic succession in western Svalbard cannot easily be correlated with its counterpart in north-east Svalbard and was probably deposited in a separate basin (Harland et al., 1993).

\section{Cryogenian events and panglaciation}

Harland (1964) championed the idea of low-latitude late Proterozoic glaciation based on globally distributed diamictites that he considered to be glacigenic and correlative. However, firmly establishing the glacial affinity of these units, determining their low-latitude origin, and confirming their correlation required another four decades (Fairchild \& Kennedy, 2007). Despite the complexity of individual successions, as summarized in Arnaud et al. (2011), it is now widely recognized that two panglacial events occurred during the Cryogenian period (ca 720 to $635 \mathrm{Ma}$ ), referred to as the Sturtian (or early Cryogenian) and Marinoan (or late Cryogenian) glaciations (Halverson et al., 2005; Macdonald et al., 2010; Hoffman et al., 2012; Calver et al., 2013; Rooney et al., 2014, 2015; Lan et al., 2014). The traditional geological interpretation of Cryogenian glaciation invoked low atmospheric $\mathrm{CO}_{2}$ levels, but it was not until whole-Earth energy balance models emerged (for example, to study a future 'nuclear winter') that it became understood that a frozen, high-albedo planet represents a stable climatic state (Budyko, 1969). Kirschvink (1992) first applied this model to interpreting the

This article is protected by copyright. All rights reserved. 
geological record, suggesting a Neoproterozoic Snowball Earth that was facilitated by low palaeolatitudes of the continents at this time and that the key to escape from the Snowball state was the build-up of volcanically derived $\mathrm{CO}_{2}$ (Caldeira \& Kasting, 1992), which at sufficiently high levels would overcome the control of the albedo of Earth's icy surface on global energy balance and trigger deglaciation. Hoffman et al. (1998) and Hoffman \& Schrag (2002) subsequently elaborated upon the Snowball Earth model and provided the first sedimentological, stratigraphic and geochemical evidence in its support. Snowball Earth theory stimulated data-collection and modelling which have significantly clarified the criteria for attribution of a suite of phenomena to Snowball Earth conditions. Neoproterozoic glaciations are associated with negative carbon isotope anomalies (Knoll et al., 1986; Kaufman et al., 1997) and Hoffman et al. (1998) argued that the anomaly apparently encompassing Marinoan glacial period reflected low organic productivity as a result of glacial climate and an ocean that became isolated from the atmosphere. Additionally, the postglacial cap carbonates and the associated negative carbon isotope anomalies were regarded as a positive test of the Snowball Earth hypothesis, reflecting rapid meltdown and requilibration of oceanic and atmospheric $\mathrm{CO}_{2}$ during a post-Snowball, ultra-greenhouse environment. However, subsequent work implies a more nuanced scenario and the interpretations of both the pre-glacial and post-glacial anomalies remain disputed (Kennedy et al., 2001a. b; Hoffman \& Schrag, 2002; Halverson et al., 2002; Schrag et al., 2002; Trindade et al., 2003; Hoffman et al, 2007; Le Hir et al., 2008, 2009; Kennedy \& Christie-Blick, 2011; Hoffman et al., 2012).

Early articulation of the Snowball Earth model lacked a framework for interpreting the glacial formations and their relevance for the theory. In the original 'hard' Snowball, a universally thick, icecover on the oceans, composed of an upper zone of glacier ice and lower zone of frozen sea water was envisaged (Pierrehumbert 2005; Pierrehumbert et al., 2011). In this scenario, sea-level should have been greatly lowered and marine ice margins should have occurred far below the shallowwater pre-glacial sediments. Evidence to support this hypothesis was found in Namibia. On platform tops, glacigenic deposits are rare, whereas on platform margins tidewater-glacier grounding-line

This article is protected by copyright. All rights reserved. 
phenomena are inferred to be some hundreds of metres lower topographically (Hoffman, 2011; Domack \& Hoffman, 2013). On the other hand, most glacial sedimentologists opposed the Snowball theory, commonly citing evidence of repeated glacial advances and retreats in marine environments, and wave-generated and storm-generated structures indicating open water inconsistent with the hard snowball scenario (Xiao et al., 2004; Etienne et al., 2007; Allen \& Etienne, 2008; Le Heron et al., 2011, 2013). Apparent support from models showing equatorial open water (e.g. Hyde et al., 2000) faced the problem that the simulated climate solutions were unstable. Hence, Hoffman (2011) responded that: "counter arguments [to the Snowball model] based on temperate-type glacial sedimentology fail to grasp that the preserved glacial sedimentary record reflects the end of the Snowball Earth, when melting was bound to emerge triumphant".

New modelling that showed stable, long-lived ice-free regions ('Waterbelts') in the tropics has motivated rethinking the Snowball glacial record (Pierrehumbert, 2011). Abbot et al. (2011) proposed the term 'Jormangund' state to describe a stable, ice-free equatorial fringe achieved as the result of the low albedo of low-latitude sea ice. Alternatively, Rose (2015) argued for an entirely new climatic state in which convergence of ocean heat transport at tropical ice edges stabilizes a belt of open water stradding the equator. Hoffman et al. (2012) noted that whereas the Jormangund state preserved the pattern of modern low-latitude climate belts, with a moister equatorial region, the hard Snowball climatic pattern (Pierrehumbert et al., 2011) would result in higher precipitation minus evaporation in the subtropics and an extremely arid equatorial zone. This important distinction draws attention to the need to study low-latitude continental glacial deposits such as the Wilsonbreen Formation where more direct evidence of climatic conditions can be obtained.

The surviving essential predictions of Snowball Earth theory can be summarized as follows: (1) globally, glaciations must occur synchronously, (2) they must be long-lasting (>1 Ma) to allow (3) the build up of atmospheric $\mathrm{CO}_{2}$ to high levels when (4) sedimentation occurs in a brief period prior to termination. Although earlier geochronological compilations had legitimate doubts about (1) and (2) (Allen \& Etienne, 2008), they are now more firmly established (Rooney et al., 2015), although the This article is protected by copyright. All rights reserved. 
duration of the Marinoan glaciation (?5 to $15 \mathrm{My}$ ) is imprecisely known. The Wilsonbreen Formation has now permitted positive tests of (3) and (4).

Compared to the Cenozoic, Neoproterozoic strata offer limited options for determining atmospheric $\mathrm{CO}_{2}$ concentrations. Bao et al. (2008) proposed a bold new approach based on processes occurring during stratospheric ozone formation which results in an enrichment in the isotope ${ }^{17} \mathrm{O}$ in ozone and carbon dioxide and depletion in oxygen $\left(\mathrm{O}_{2}\right)$. This non mass-dependent effect does not influence ${ }^{18} \mathrm{O}$ abundances. The ${ }^{17} \mathrm{O}$ signal can be preserved in the oxygen atoms of sulphate in rocks if atmospheric oxygen is used to oxidize sulphides on the land surface. Sulphate has the fortuitous property of not exchanging oxygen atoms with other species over $1000 \mathrm{Myr}$ timescales at surface conditions, provided it is not subject to microbial redox cycling. Bao et al. (2008) showed that at time periods when atmospheric $\mathrm{PCO}_{2}$ was enhanced, sulphate in the geological record was ${ }^{17} \mathrm{O}$-depleted. The most significant anomaly was discovered in barite crystal fans within the carbonate succession overlying Marinoan glacial diamictites in South China.

Bao et al. (2009) subsequently found more profound ${ }^{17} \mathrm{O}$-deficiencies in carbonateassociated sulphate (CAS) in lacustrine limestone of the central part (member W2) of the Wilsonbreen Formation, consistent with very high atmospheric $\mathrm{PCO}_{2}$ actually during glaciation. More recent studies in other geographic regions, coupled with process modelling approaches, have supported evidence for high $\mathrm{PCO}_{2}$ during deposition of Marinoan cap carbonates (Bao et al., 2012; Cao \& Bao, 2013; Killingsworth et al., 2013; Bao, 2015), but the Wilsonbreen Formation remains the only unit where $\mathrm{PCO}_{2}$ can be estimated during glaciation.

Benn et al. (2015) applied the same approach to a much larger dataset of limestones from members W2 and W3 to argue that similar high $\mathrm{PCO}_{2}$ values (estimated at 10 to 100 mbar atmospheric $\mathrm{CO}_{2}$ ) occurred throughout the deposition of the Wilsonbreen Formation. Because it would have taken a long time to accumulate $\mathrm{CO}_{2}$, these authors inferred that the bulk of the Wilsonbreen Formation was deposited in a relatively short period near the end of the glaciation. In

This article is protected by copyright. All rights reserved. 
turn, this implies an extended hiatus early in the glaciation, which manifested as a permafrosted horizon at the base of the Wilsonbreen Formation.

Coupled ice sheet and atmospheric general circulation model results in Benn et al. (2015), using Snowball Earth boundary conditions at 20 mbar atmospheric $\mathrm{PCO}_{2}$, display thick glaciers on the continents coexisting with extensive areas of bare ground and widespread hyperaridity. Under these conditions, the climatic consequences of orbital precession cycles is to force ice margins to migrate by at least hundreds of kilometres, and the present authors link this cyclicity to the presence of distinct ice advances within the Wilsonbreen Formation (Fig. 1). The presence of an arid tropical continent during the Marinoan ice age is also consistent with observations of periglacial structures, aeolian, fluvial and evaporative floodplain facies in the Australian Marinoan successions (Williams, 2008; Ewing et al., 2014; Retallack et al., 2015). Although conclusions based on the Marinoan glaciation should not necessarily apply to the much longer Sturtian glaciation, the new results provide a way to reconcile the opposed positions stated in Allen \& Etienne (2008), of temperate glacial conditions during panglaciation, and Hoffman (2011), of sediment deposition occurring rapidly during meltdown (Allen, 2015). The purpose of this contribution is to provide a detailed sedimentological analysis of the Wilsonbreen Formation as template for glacial sedimentation in the terrestrial realm during Snowball glaciation and to investigate the geomorphic-climatic system in which the Wilsonbreen carbonates were deposited. This analysis begins by examining the most plausible modern analogue.

\section{The Antarctic McMurdo Dry Valleys as analogues for the Wilsonbreen Formation carbonates}

Walter \& Bauld (1983) were the first to attempt to compare the frigid, arid Dry Valleys region with carbonates and associated facies in Neoproterozoic successions, but the Australian examples chosen were either postglacial or had an uncertain relationship to glaciation. Later, Fairchild et al. (1989) made a more specific comparison with member W2 of the Wilsonbreen Formation. Conversely,

This article is protected by copyright. All rights reserved. 
leading workers on the Dry Valleys (Lyons et al., 2001) commented that they might compare with Proterozoic Snowball Earth; they have also been used as analogues for the Martian surface (Marchant \& Head, 2007; Dickson et al., 2013). The local 'alpine' glaciers of the Dry Valleys are coldbased, but outlet glaciers such as the Taylor Glacier are warm-based, albeit because of sitting in a saline basin (Mikucki \& Priscu, 2007). Given the criteria for recognition of glacial thermal regime presented by Hambrey \& Glasser (2012), warm-based analogues are needed to understand much of the glacigenic facies of the Wilsonbreen Formation (Fleming et al., 2016). Nevertheless, for the carbonate facies, the context of the Dry Valley region, provides unique parallels for the following evidence provided by Fairchild et al. (1989): (i) a record of extreme evaporation with an interpreted up to $20 \%$ difference in $\delta^{18} \mathrm{O}$ between input waters and those responsible for the precipitation of the carbonates with heaviest $\delta^{18} \mathrm{O}$ signatures; and (ii) alternating deposition of glacial sediment and continental deposits indicating ice advance and retreat, specifically including rhythmic and microbial, presumed lacustrine carbonates and evidence of former evaporites.

Figure 3 illustrates the geographical context of the Dry Valleys region, which has been studied extensively over several decades by groups led from New Zealand, Japan and the USA, with Taylor valley being the focus since 1993 of the McMurdo Dry Valleys Long-term Ecosystem Research (LTER) Program of the National Science Foundation. The Dry Valleys occupy $4800 \mathrm{~km}^{2}$ in the Transantarctic Mountains between the East Antarctic Ice Sheet (EAIS) and the Ross Sea. The individual valleys mostly trend east-west and are up to $80 \mathrm{~km}$ long and $15 \mathrm{~km}$ wide and are internally drained, commonly with several discrete lake basins in each valley. Two outlet glaciers from the EAIS (Wright Upper and Taylor glaciers) only just cross the regional bedrock altitude divide into the eastward-draining catchments, whilst Ferrar Glacier flows all the way to the coast (Fig. 3). Local valley glaciers extend from the mountains into dry valleys, for example, Canada Glacier in Taylor Valley (inset in Fig. 3) and ephemeral streams develop in summer. A variety of lakes occur, including those occupied by ice frozen to the bed in the relatively high-altitude Victoria Valley, highly saline lakes with no ice cover (for example, Don Juan Pond, Upper Wright Valley) and finally lakes

This article is protected by copyright. All rights reserved. 
with a 3 to $5 \mathrm{~m}$ ice cover (for example, Lakes Brownsworth and Vanda in Wright Valley, and Lakes Bonney, Hoare and Fryxell in Taylor Valley), which melt only in a marginal moat in summer (Green \& Lyons, 2009; Dickson et al., 2013). Microbe-dominated biotas flourish wherever and whenever liquid water is present, including as mats on stream and lake beds. Photosynthesizing algae are important in lakes during the spring season (Fountain et al., 1999). Microbial mats consume nutrients rapidly from stream water, and biogeochemical cycling in these systems is strongly influenced by exchange of hyporheic waters with stream water (McKnight et al., 1999).

Microclimates in the Dry Valleys comprise a coastal zone, with soils that transiently thaw in summer, and a stable cold upland zone with particularly low relative humidity (Marchant and Head, 2007; Marchant et al., 2013). The intervening valleys have a mean annual temperature of -16 to $21^{\circ} \mathrm{C}$ and the maximum average daily temperature is below zero throughout the year (Fountain et al., 1999). The valleys receive less than $10 \mathrm{~mm}$ water-equivalent of precipitation per year, almost always as snow. Because of the prevailing low relative humidities (for example, between $50 \%$ and $60 \%$ in Taylor Valley, Fountain et al., 1999), ablation (mostly as sublimation) greatly exceeds precipitation. Wilson (1981) described the consequences of this geographic configuration and climatology using physical and chemical principles. The amount of precipitation rises with altitude, but falls inland further from the Ross Sea. The snowline marks the boundary where ablation exceeds precipitation and it rises inland as precipitation declines. Wilson (1981) attempted to explain the distribution of salts based on an understanding of downslope-increasing aridity, but it seems that variable meteorology confounds the predictions in detail. Nevertheless, it is the case that deliquescent salts flow downhill in the sub-soil above a permanently frozen layer. Lakes with a lid of ice maintain mass balance between ablation at the surface and freezing of lake water at the base of the lid, replenished seasonally by stream inflow. Once snow is removed by ablation, sunlight penetrates through vertical ice crystals and significant solar heating of lakes can occur. The present configuration of salts allows deductions of both long-term and short-term history. Specifically, spatial variability in salts requires a long-term $\left(>10^{5}\right.$ to $10^{6}$ years $)$ stability of the ice-free subaerial

This article is protected by copyright. All rights reserved. 
valley sides. On the other hand, some lakes have a basal brine layer, which diffusion modelling shows originated ca 1200 years ago when some lakes were ice-free shallow brines, before being refilled by fresh meltwater.

Wilson (1981) did not address the effect of wind on aridity and salt distribution. Katabatic winds flowing down the East Antarctic Ice Sheet strongly enhance aridity regionally. As this air warms adiabatically, humidity decreases, particularly in winter (Nylen et al., 2004). It is now clear that the episodically strong summer winds are actually warm foehn winds, which arise from strong pressure gradients that arise during cyclonic development over the Ross Sea, governed by hemispheric climatic anomalies. These topographically enhanced and channelled winds typically flow at $>5 \mathrm{~m} \mathrm{~s}^{-1}$ westerly along the Dry Valleys and cause very large intra-annual and inter-annual increases in meltwater production and streamflow (Doran et al., 2008; Speirs et al., 2013). The high incidence of these winds in summer 2001/2002, when positive degree days increased by an order of magnitude, led to rises in lake level of 0.5 to $1.0 \mathrm{~m}$, effectively wiping out the previous 14 years of lowering of lake level in a period of three months (Doran et al., 2008). These details effectively demonstrate the sensitivity of the environment to climatic changes, which in turn will strongly influence sedimentary facies.

The Dry Valleys region and the adjacent offshore area, seaward of Ferrar Glacier, demonstrate a 34 Myr history of glaciation. Cores from several offshore drillholes indicate that the first evidence of glaciation was at the Eocene/Oligocene boundary, and that the thermal characteristics of the glaciers changed from temperate (associated with abundant flora), through polythermal conditions to the predominantly cold glaciers of today (Hambrey \& Barrett, 1993; Hambrey et al., 2002; Barrett, 2007; Naish et al., 2008). The McMurdo region has generated considerable controversy concerning the timing of the switch to cold, arid conditions, specifically whether the switch took place in Miocene or Late Pliocene time; these views have been reviewed and re-evaluated by Barrett (2013). Evidence for landscape evolution based on the position of Miocene volcanic ash deposits clearly demonstrates that after the establishment of the current

This article is protected by copyright. All rights reserved. 
large, cold, and stable East Antarctic Ice Sheet in the Miocene, only surficial landscape modification has occurred (Sugden et al., 1995; Lewis et al., 2007). Importantly, the cold, dry climates of the Dry Valleys remained stable, even during significant warming events recorded in the Ross Sea during the Pliocene. This long-term climatic stasis can be compared with the predicted long-term hydrological inactivity anticipated on a Snowball Earth as carbon dioxide levels slowly rose.

Large lakes formed during the Last Glacial Maximum in all the major Dry Valleys - this required two conditions: (i) expansion of the Ross Sea Ice sheet to block the marine margins of the Dry Valleys (Hendy, 1980; Hall et al., 2013); and (ii) increased meltwater production in the valley (by wind-induced melting, Doran et al., 2008), despite significantly colder conditions. Conversely, dating of aragonitic lacustrine deposits shows that Taylor Glacier (with characteristically light oxygen isotope values) expanded during interglacial periods, as did local valley-side glaciers, which have heavier isotope values (Hendy 1979, 1980). These phenomena presumably reflect higher snow accumulation on the EAIS, enhanced meltwater production, and partial blockage of the valley by ice. Importantly, these inferences draw attention to the potential anti-phasing of global temperature and local glacier advance and the greater importance of regional humidity controls on Milankovitch timescales.

In the current paper, a wealth of new data on the Wilsonbreen Formation carbonates are presented which allows the analogies previously made to be tested and evaluated in depth. The interpretation of these data is assisted by modern analogues and new computer simulation studies of Neoproterozoic climates (Pierrehumbert et al., 2011, Benn et al., 2015).

\section{METHODS}

Fieldwork (2010/2011) was supported by helicopter and by snow scooter. Sections, including six entirely new locations, were measured by $30 \mathrm{~m}$ tape, orientated by compass and Abney level, and linked to bedding dips, with total thickness checked by GPS with uncertainty of around $5 \%$. The best

This article is protected by copyright. All rights reserved. 
available sections in each region were logged (Figs 1 and 2), although they vary in quality from almost complete exposure, to intermittent outcrop separated by ground-level frost-shattered regolith. The carbonate rocks are chemically fresh, but laboratory study of cut or sectioned samples was necessary to identify facies in many cases. Over 350 samples were sawn, 210 of which were thin-sectioned; 60 of these were stained with Alizarin Red-S and potassium ferricyanide and over 30 polished sections were studied by cold-cathode cathodoluminescence (CL) at $15 \mathrm{kV}$.

Carbon and oxygen stable isotope data are presented here as $\delta^{13} \mathrm{C}$ and $\delta^{18} \mathrm{O}$ in parts per thousand with respect to the VPDB (Vienna Pee Dee Belemnite) standard. Differences between laboratories are insignificant in relation to the wide range of isotope values $\left(29 \%\right.$ in $\delta^{18} \mathrm{O}$ and $8 \%$ in $\delta^{13} \mathrm{C}$ ) in this study. Supplementary data in Bao et al. (2009) included methods and all data collected to that date. New data were obtained at the University of Birmingham using a continuous-flow Isoprime IRMS, with a multiflow preparation system. Samples of between 80 to $250 \mu \mathrm{g}$ powdered carbonate were reacted with phosphoric acid at $90^{\circ} \mathrm{C}$ for at least 90 minutes. Results were calibrated using IAEA standards NBS-18 and NBS-19 and repeatability on an internal standard was better than $0.1 \%$ for $\delta^{13} \mathrm{C}$ and $0.15 \%$ for $\delta^{18} \mathrm{O}$. A fluid inclusion study is reported in the supplementary information. Sulphate oxygen and sulphur isotopes are presented in Benn et al. (2015). The present study draws on previously presented trace element data from the carbonate fraction soluble in dilute nitric acid (Fairchild \& Spiro, 1987; Fairchild et al., 1989; Bao et al., 2009), whilst new trace element and other isotope analyses will be presented elsewhere.

In figure captions, the location and stratigraphic position are given in a standard format. For example, 'W2, Dracoisen, $70 \mathrm{~m}$ ' refers to a sample from member W2 from the Dracoisen section, 70 $\mathrm{m}$ above the base of the Formation (or the base of the section where the base is not seen). The context and oxygen isotope composition of the carbonate from that horizon can be found in the stratigraphic section diagrams: Fig. 4 for Dracoisen and supporting Figs 1 to 6 for the other sections. Carbonates in members W1 and W3 are summarized only in Table 2, but full stratigraphic logs of the Wilsonbreen Formation are given in Benn et al. (2015, their fig. S1).

This article is protected by copyright. All rights reserved. 


\section{WILSONBREEN FORMATION ARCHITECTURE, COMPOSITION AND POST-DEPOSITIONAL HISTORY}

The Wilsonbreen Formation, dominated lithologically by sandy diamictites, contains a wealth of evidence indicating that it is largely glacigenic, and was deposited in both aqueous and subglacial settings (Hambrey 1982; Fairchild \& Hambrey, 1984; Dowdeswell et al., 1985; Harland et al., 1993). New work (Benn et al., 2015; Fleming et al., 2016), including five previously undescribed sections, has resulted in a coherent stratigraphic-facies reconstruction (Fig. 1). This paper focuses on beds (sandstones, rhythmites and mudrocks) containing precipitated carbonate; the presence of such strata was originally used to define member W2 (Hambrey, 1982). In the northernmost section (Dracoisen), W2 is readily distinguished by three such carbonate-bearing beds separated by diamictites (Fig. 2A), and overall a similar pattern applies in other sections (Fig. 1). However, thin rhythmite units also occur in member $\mathrm{W} 1$, one containing precipitated carbonate, and most of the thin non-diamictite (sandstone and rhythmites) beds in member W3 contain such carbonate facies (Table 2). Although glacigenic rocks continue NNE to the coast and to Nordaustlandet, these were not included in our study since diamictites are thinner and less well exposed, and precipitated carbonates are absent (Halverson et al., 2004; Hoffman et al., 2012). Neither do such carbonates occur in the equivalent Storeelv Formation of Northeast Greenland, representing the south-western continuation of the basin (Hambrey \& Spencer, 1987; Moncrieff \& Hambrey, 1990; Hoffman et al., 2012, Fleming, 2014).

\section{Terrigenous detritus}

Clarifying the nature of reworked (terrigenous) clastic material is important for the petrological study of the Wilsonbreen Formation. Harland et al. (1993) summarized information from five sites, determining that carbonate clasts make up 40 to $85 \%$, igneous and metamorphic clasts 5 to $33 \%$ and sandstones and quartzites 10 to $20 \%$ of stones (i.e. gravel-sized debris); the basement lithologies are

This article is protected by copyright. All rights reserved. 
primarily granitoids and gneisses, with some basalt in which ferromagnesian minerals are commonly chloritized. In the wider context of terranes affected by the Caledonian orogen, detrital zircon studies indicate provenance from Archaean and Palaeoproterozoic rocks of the cratonic interior, and Mesoproterozoic detritus derived from the eroded remnants of the Grenville-Sveconorwegian orogen (Cawood et al., 2007). A systematic study of carbonate clast compositions will be presented elsewhere, but in summary $80 \%$ of pebbles are dolomite rock and $20 \%$ are limestone. Many of these carbonates resemble units from the underlying succession (Table 1) in lithology and isotope composition, but no stratigraphic trends in clast type or isotope composition were found. The sand fraction is dominated by quartz and feldspar with subordinate dolomite and limestone and the mud fraction likewise comprises quartzo-feldspathic debris and dolomite (Fig. 5). The dominance of silt in the mud fraction is shown in graded rhythmites (Fig. 5B and C); notably detrital calcite occurs in the mud fraction only locally and the proportion of clay minerals is very low. The dolomite matrix of Polarisbreen Group diamictites is predominantly the result of glacial transport and comminution as shown by the presence of sub-micron relic rock flour (Fairchild, 1983) in which clay minerals are virtually absent (Fig. 5D). This detrital matrix contains a complex mixture of both bright and dully luminescent red dolomite when viewed in $\mathrm{CL}$ (Fig. $5 \mathrm{C}$ ). The mean carbon and oxygen isotope compositions of dolomitic matrix in diamictites and wackes $(n=43)$ are $+2.4 \pm 1.3 \%$ o and $-3.5 \pm 1.8 \%$ o respectively, which are slightly lower values than for dolomite pebbles (Fig. 6A). This matrix composition forms a useful reference point for comparison with precipitated carbonates in the Wilsonbreen Formation.

\section{Burial diagenetic modification}

The Wilsonbreen Formation is overlain by a marine transgressive succession, but above the transgressive-regressive cycle of the lower Dracoisen Formation, most Ediacaran strata (Table 1) are non-marine playa lake facies, in turn overlain by $950 \mathrm{~m}$ of Cambro-Ordovician platform carbonates

This article is protected by copyright. All rights reserved. 
(Harland, 1997), indicating a minimum burial of $1.5 \mathrm{~km}$. Late Silurian Caledonian folding and local thrusting followed (Fig. 2), but small-scale folding is generally absent, as is penetrative deformation. The Wilsonbreen Formation lies outside the thermal aureoles of Devonian granite plutons in the fold belt (Harland, 1997). Pores in the cap carbonate are filled with traces of bitumen, indicating that the sediments passed through the oil window, but good preservation is indicated by the ability to remove individual striated clasts from diamictite matrix (Hambrey, 1982) and some unusually high oxygen isotope compositions of dolomites (Fairchild et al., 1989; Bao et al., 2009). A fluid inclusion study (see supporting information) indicates that initial pore fluids were advectively replaced by a typical meteoric fluid with $\delta^{2} \mathrm{H}$ in the range -60 to $-100 \%$ and that ${ }^{18} \mathrm{O}$ is slightly enriched by exchange with the solid phase. However, fluid inclusion volumes are orders of magnitude too small to have affected the bulk solid composition. Physical compaction effects are not noticeable because of the low clay content of the sediments and early cementation of the carbonates, but very locally lamina boundaries are styolitic. Uncemented sandstones exhibit straight to concavo-convex boundaries between quartz grains.

Many Wilsonbreen Formation outcrops are reddened, and even in unreddened facies, organic carbon contents are low (below detection levels of $0.2 \%$ on three W2 carbonates). Fairchild \& Hambrey (1984) regarded the haematite pigment as post-depositional based on the occurrence of Liesegang band structures. Ongoing palaeomagnetic studies may further elucidate timing of this haemitization. Reddening is less pervasive in clean sandstones, implying that the source of iron in reddened zones is the fine fraction. The low preservation of organic carbon may reflect low abundance of clay (Kennedy et al., 2006) as well as a low-productivity continental setting. In either case, it permitted the diagenetic reddening, which contrasts with the dark-coloured early Cryogenian glacimarine deposits in the study area (Member E2, Table 1).

Burial cements are minor and readily distinguished from syn-depositonal phenomena. Limited quartz overgrowths are common in sandstones and on sand grains floating in dolomites, whilst some sandstones display partial poikilotopic calcite cement. Ferroan saddle dolomite and

This article is protected by copyright. All rights reserved. 
ferroan calcite occlude larger primary pores, in dolomites and limestones respectively. These carbonate phases also occur, locally together with quartz and white mica in crystal pseudomorphs. Saddle dolomite averages $-12.2 \pm 1.5 \%$ in $\delta^{18} \mathrm{O}$ and $-1.8 \pm 1.5 \%$ in $\delta^{13} \mathrm{C}$ and calcite spar $-10.5 \pm 1.6 \%$ o and $+2.0 \pm 1.5 \%$, respectively (Bao et al., 2009).

\section{FACIES ANALYSIS}

\section{Facies Associations}

Following Benn et al. (2015) seven facies associations (FAs) are recognized in the Wilsonbreen Formation. Table 3 presents summary descriptions and interpretations, whereas Fig. 7 illustrates inferred environments. The glacial and periglacial facies associations (FA1, 6 and 7) are discussed in Hambrey (1982), Fairchild \& Hambrey (1984), Benn et al. (2015) and Fleming et al. (2016), and only a few salient points are mentioned here. Two distinct glacier advances from the south are recognized, just below and above member W2, by occurrences of FA1: sheared diamictite, sandstones and gravels, locally resting on highly deformed rhythmites (glacitectonites) or striated clast pavements

(Fig. 1, labelled FA1 subglacial). The bulk of the Wilsonbreen Formation is, however, composed of weakly stratified diamictites (FA6) with decimetre to metre-scale lenses of rhythmites (with precipitated carbonate in members W2 and W3). Local presence of dropstones or isolated gravel clasts (lonestones), till pellets and stratification, and the absence of subglacial shearing phenomena, point to a subaqueous ice-rafted origin. Local lensing conglomerates are interpreted as sedimentgravity flows which, at Dracoisen, comprise a conspicuous low-angle cross-stratified unit (Fig. 1, labelled FA6, proximal), interpreted as a grounding-line fan (Benn et al., 2015; Fleming et al., 2016). Gravel with ventifacts overlying shattered dolomite represents the Periglacial Facies Association (FA7) at the base of the Wilsonbreen Formation, interpreted as a multi-million year continental hiatus (Benn et al., 2015). Facies association 7 also occurs at the base of W2 where a

This article is protected by copyright. All rights reserved. 
periglacial exposure horizon with sandstone wedges penetrating subglacial till occurs (Fig. 1) at South Ormen (ORM), South Klofjellet (KLO) and Ditlovtoppen (DIT) and also at the Golitsynfjellet (GOL) section (Fairchild et al., 1989), which is between McDonaldryggen (McD) and the Backlundtoppen-Kvitfjella Ridge (BAC). The periglacial horizon is overlain by sandstones correlated with those at the base of W2 at Dracoisen (Dracoisen).

The other four Facies Associations contain precipitated carbonate and are described in detail below with summaries presented in Table 3 and Fig. 7. Each of the Facies Associations occurs as units 0.1 to $4.0 \mathrm{~m}$ in thickness (Fig. 4 and supporting information Figs S1 to S6).

\section{Facies Association 2 (Facies 2S and 2T)}

\section{Description}

This facies association is represented by erosionally-based, fining-upward tabular sandstone beds, 0.5 to $4.0 \mathrm{~m}$ in thickness. Facies $2 \mathrm{~T}$ typically comprises moderately sorted very fine to mediumgrained sandstone with a basal erosional surface capped by a gravel lag. Internal cross-stratification is tabular, typically with low-angle accretion surfaces and set thickness of 0.5 to $1.0 \mathrm{~m}$. This facies is seen at the base of the W2 section at Ditlovtoppen (Fig. S1), South Ormen (Fig. S2), East Andromedafjellet (Fig. S3) and Reinsryggen (Fig. S4), and is also prominent near the top of the member at Dracoisen (Fig. 8H) and at Ditlovtoppen, where thin siltstone beds define low-angle accretion surfaces (Fig. 8G).

Facies $2 \mathrm{~S}$ is distinguished from Facies $2 \mathrm{~T}$ by the presence of limestone laminae and intraclasts, and reduced silt content. The best-exposed example is a $4 \mathrm{~m}$ thick unit that forms the basal part of member W2 at Dracoisen (Figs 2A and 4), resting on massive diamictite with decimetrescale erosional relief. A thin basal pebble conglomerate passes up into $0.7 \mathrm{~m}$ of pebbly sandstone, whereas the main, central part of the bed is very fine to medium-grained sandstone with local tabular cross-stratification, with set thickness up to $15 \mathrm{~cm}$ and current ripples (Fig. 8D). At both

This article is protected by copyright. All rights reserved. 
levels, there are abundant (ca 25 to 50\%) layers of limestone, with individual laminae typically 1 to 3 $\mathrm{mm}$ thick (Fig. 8A). Universal features of the limestone are domed growth morphologies (Fig. 8A) and differentiated microstructures (Fig. 8B) with well developed slightly irregular laminae of micrite, microspar and detritus-rich carbonate with regular millimetre-scale fenestrae (Fairchild, 1991; Riding, 2000). In one case a pervasive vertical structure reminiscent of cyanobacterial or algal filament moulds (Knoll et al., 1991) was observed (Fig. 9B). All limestone occurrences are laterally discontinuous, and grade laterally to trains of intraclasts that are locally stacked at high angles. In places, extensive crusts, up to 0.5 to $6.0 \mathrm{~mm}$ thick, of radiaxial calcite cement develop, also broken to form intraclasts (Fig. 8C).

Under CL, intraclasts fluoresce uniformly brightly, whereas later vein cements show more variable characteristics (Fig. 9A). This pattern is mirrored geochemically in high $\mathrm{Mn}$ contents of several thousand ppm and exceptionally high Mn/Fe of 1 (Bao et al., 2009) of the intraclasts. Strontium contents are 150 to 300 ppm, whilst Mg is 4000 to 6000 ppm (Bao et al., 2009), equivalent to $c a 2$ mole $\% \mathrm{MgCO}_{3}$. The radiaxial fabrics appear pristine and microdolomite inclusions are absent. Sulphate content is high (2000 to 5000 ppm, Bao et al., 2009), whereas the preservation of a negative $\Delta^{17} \mathrm{O}$ anomaly demonstrates that the sulphate has not undergone redox cycling (Bao et al., 2009; Benn et al., 2015). Stable isotope data from stromatolitic limestones define a coherent field (Fig. 6A) with $\delta^{18} \mathrm{O}$ ranging from -10.5 to $-3.4 \%$ and $\delta^{13} \mathrm{C}$ from +0.9 to $+4.6 \%$, weighted towards higher values, with overall isotopic covariation (Fig. 6B). A micromill traverse through syndepositional calcite reveals lamina-to-lamina variations of $2.0 \%$ in $\delta^{18} \mathrm{O}$ and $0.5 \%$ in $\delta^{13} \mathrm{C}$, without strong covariation (Fig. 8E and F). The clear petrographic distinction between syndepositional and later calcite spar cement is reflected also in the low $\delta^{18} \mathrm{O}$ signature of the spar of 10 to $-12 \%$ (Fig. $8 \mathrm{~F})$.

This article is protected by copyright. All rights reserved. 
Interpretation

Facies Association2 is distinguished by tractional sediment transport. The consistent presence of laterally extensive basal erosion surfaces imply channelization, whilst for Facies $2 \mathrm{~T}$ the low-angle accretion surfaces with thin silt beds suggests migrating point-bar deposits (Davies \& Gibling, 2010), although confirmation would require more extensive exposures. The presence of high-angle crossstratification, good sorting, and disrupted intraclasts in Facies 2S are characteristics found in either tidal sand flats or in low sinuosity fluvial channels. The limestones contain two features typical of Neoproterozoic microbial deposits: macroscopically domed laminae and differentiated microstructures formed by periodic variations in phenomena such a sediment trapping, gas generation and carbonate precipitation, fulfilling criteria for stromatolites (Fairchild, 1991; Riding, 2000). Limestones were lithified as demonstrated by broken crusts and dispersed and stacked intraclasts, for example along foresets, as expected for significant tractional flows in shallow water. The later disruption and discontinuity of the limestone units indicates highly variable flow conditions, whereas the locally highly regular microbial lamination, including clastic layers, indicates periodically fluctuating flows.

Facies $2 \mathrm{~S}$ resembles tidal sandflat deposits, consistent with the occurrence of well-preserved radiaxial cements with relatively high $\delta^{18} \mathrm{O}$ compositions (Fairchild \& Spiro, 1987). However, there is an absence of herringbone cross-stratification and reactivation surfaces which commonly occur in such facies (Fairchild, 1980; Fairchild \& Herrington, 1989). There is a clear contrast with the more regular macrostructures of marine stromatolites elsewhere in the basin (Fairchild \& Herrington, 1989; Knoll \& Swett, 1990; Halverson et al., 2004) and Neoproterozoic deposits more generally (Grotzinger \& Knoll, 1999). This may be attributable to a more hostile environment, with highly variable rates of sedimentation. Furthermore, unlike the Facies $2 \mathrm{~S}$ stromatolites, Neoproterozoic peritidal deposits are invariably dolomitized (Knoll \& Swett, 1990), probably a feature of high Mg/Ca in seawater (Hood \& Wallace, 2012).

This article is protected by copyright. All rights reserved. 
The present authors favour a freshwater, fluvial context for this facies association. It is recognized that radiaxial fabrics are not diagnostic of marine waters, but also occur in speleothems (Neuser \& Richter, 2007). Furthermore a non-marine environment is consistent with the relative low Sr content of the calcite (Fairchild \& Baker, 2012). Hence, the radiaxial calcite is interpreted here as the pristine original low-Mg calcite phase. Micrite and microspar fabrics have similar chemistries and are also considered to reflect depositional conditions. Following the same arguments made for stable isotopes, the implication is that the Mn content of FA2 calcites is also primary and reflects low contemporary atmospheric $\mathrm{PO}_{2}$ (cf. Hood \& Wallace, 2014), but not anoxic conditions under which sulphate reduction would have occurred, disturbing the $\Delta^{17} \mathrm{O}$ systematics and producing sulphides (Bao et al., 2009). Importantly, the Mg composition of facies $2 \mathrm{~S}$ limestone is similar to modern speleothem deposits in a cool Scottish cave depositing from waters with $\mathrm{Mg} / \mathrm{Ca}$ controlled by dolomite dissolution (Fairchild et al., 2001). The lamina thickness of the stromatolites is very similar to those of modern fluvial microbial tufas which are similarly complex deposits containing both biologically mediated and inorganic precipitates (Andrews \& Brasier, 2005; Andrews, 2006). Interestingly, the lamination of these modern deposits reflects a strong annual variation in discharge; Facies $2 \mathrm{~S}$ likewise possesses physical sedimentological characteristics consistent with those of ephemeral streams. In this interpretation, the stable isotope compositions, which are similar for radiaxial and microsparry calcites, can also be interpreted as primary, in which case the isotopic covariation (Fig. 6B) reflect an evolutionary trend towards more evaporated equilibrated solutions (Talbot, 1990), rather than variations associated with recrystallization. Modern Antarctic streams lack the calcite mineralization, but microbial mats are well-developed and are adapted to ephemeral flow conditions, readily reactivating even after being dry for many years (McKnight et al., 2007). The fluvial interpretation will be developed later in the light of the relationship of FA2 to other facies associations.

This article is protected by copyright. All rights reserved. 


\section{Facies Assocation 3 (Facies 3D and 3S)}

\section{Description}

Facies 3D is marked by discrete zones of pronounced dolomite cementation within a sandstone or siltstone, in some cases pervasive. Where dolomite is most abundant, detritus floats in a displacive mass of dolomite crystals (Fig. 10B, D, E and F), but other dolomite-cemented silty sands are still clast-supported (Fig. 10C). Locally, distinct dolomite-cemented nodules are visible (Fig. 10A) or a structureless dolomite bed occurs with a low content of floating silt and sand. The most characteristic structures are millimetre-scale nodular dolomicrite structures within massive dolomite-cemented layers and associated with calcite-filled fractures. These phenomena are found at one horizon in member W3 (Fig. 10D), as well as in several locations in member W2 (for example, Fig. 10F). A rarer phenomenon is the presence of equant centimetre-scale cauliflower-shaped pseudomorphs, filled by ferroan saddle dolomite cement (Fig. 11A) occurring at the top of a conglomerate-based fining-upward cycle (Fig. 8G). Since saddle dolomite is a burial phase (Radke \& Mathis, 1980), the pseudomorphs must have been occupied with soluble crystals that dissolved during burial prior to cementation.

Facies 35 refers to dolomitic laminites, with broad centimetre-scale domed macrostructure, with an aspect ratio of 10:1; they are found uniquely in a single complex bed, in association with Facies 3D, and overlying facies 2S (at $70 \mathrm{~m}$, Dracoisen, Fig. 4). It has been studied on the 'Multikolorfjellet' cliffs and the 'Tophatten' nunatak $1 \mathrm{~km}$ to the north. The bed is around a metre in thickness, and has an internally variable structure. Most commonly the base of the bed shows minor erosion of underlying diamictite and begins with crudely laminated, very fine to medium-grained green sandstone, locally with millimetre-scale limestone layers that are partly disrupted into intraclasts (Facies 2S). In places, the limestone passes upward into intensively dolomite-cemented sand in which the rock fabric appears to have expanded. In this sand dolomite corrodes quartz detritus and there are cavities lined with dolomicrospar and occluded by calcite. At the 'Tophatten'

This article is protected by copyright. All rights reserved. 
locality, a chaotic breccia unit a few decimetres thick is locally found at the base of the bed instead of sandstone. Everywhere, the top of the bed is marked by 10 to $20 \mathrm{~cm}$ of dololaminites with a complex microstructure, which alternate on a centimetre-scale with displacively cemented sands (Fig. 10E). The laminae are variably composed of dolomicrite or dolomicrospar and contain common fenestrae (Fig. 9E and H), whilst weathered surfaces reveal a finely textured microtopography (Fig. 10G). Locally, slightly lower in the bed, limestone laminites (FA5) form a $10 \mathrm{~cm}$ horizon overlying a 20 to $30 \mathrm{~cm}$ chaotic carbonate breccia (Fig. 10I) and gradually become disrupted downward.

Dolomite from FA3 is characteristically bright under CL (Fig. 11B to D). In facies 3S, dolomicrite clots are uniformly bright, whilst adjacent dolomicrospar displays duller growth filling small fenestrae whilst larger fenestrae are filled by dolospar with more variable properties (Fig. 11B). Manganese (3000 to 4000 ppm), Fe (10000 to 15000 ppm), Na (2000 ppm) and Sr (250 to 350 ppm) concentrations are all unusually high (Bao et al., 2009), and our unpublished electron microsope images and microanalyses also show enrichments in many transition metals and rare earths, as well as a consistent chemical zonation within crystals of dolomicrite mosaics. In facies 3D, a difference in mean CL brightness, and hence timing of growth, is observed between some nodules and surrounding matrix (Fig. 11D), whilst zonation within individual crystals growing between siliciclastic sand grains is observed locally (Fig. 11C). Sulphate is enriched (4000 ppm); there is no $\Delta^{17} \mathrm{O}$ anomaly but sulphate $\delta^{18} O$ is exceptionally high (Bao et al., 2009; Benn et al., 2015).

Carbon and oxygen isotope values are correlated in FA 3D (Fig. 6), but Fig. 12 illustrates that the two analyses from member W3 lie about $1 \%$ higher in $\delta^{13} \mathrm{C}$ than expected from this trend. Facies 3D has a range of $\delta^{18} \mathrm{O}$ from -1.9 to $+11.4 \%$, but the mean value is biased upward by multiple analyses from a single sample which passes up into facies 35 with even higher values (Fig. 12). Facies $3 \mathrm{~S}$ is notable for possessing possibly the heaviest oxygen isotope values of carbonate rocks so far recorded in the geological record (Bao et al., 2009), with values up to $+14.7 \%$ (VPDB; Fig. 12). A micromill traverse (Fig. $10 \mathrm{H}$ and J) demonstrates that these extreme high values are maintained on the millimetre-scale, but that over petrographic boundaries, $\delta^{18} \mathrm{O}$ values can vary by as much as $6 \%$. This article is protected by copyright. All rights reserved. 
Interpretation

For Facies 3D, the dolomicritic, syndepositional, passive to displacive growth with nodular structure and cracks is characteristic of calcretes in which precipitation is driven by evaporative concentration at or above a water table. Although rare, the spar-filled pseudomorphs (Fig. 11A), interpreted to have originated as anhydrite (Fairchild et al., 1989), attest to evaporative conditions. The displacive growth, nodules and cracks identify these carbonates as alpha calcretes (Wright, 1990) which in Phanerozoic examples tend to occur on non-carbonate substrates and in more arid conditions than the more common beta calcretes that are influenced by higher plants (Wright \& Tucker, 2009). The strongly positive $\delta^{18} \mathrm{O}$ values and covariation with carbon isotopes require evaporation (Fairchild et al., 1989), which at the higher end of the spectrum necessitates an extremely arid environment. Dolocretes are less common than calcareous calcretes and tend to be better developed when originating from groundwater than when pedogenic, as in Triassic strata of the Paris Basin (Spötl \& Wright, 1992). In this example, pedogenic and groundwater dolocretes had a similar range of stable isotope compositions to each other, but their covariance slope (1:1) was steeper than in FA3. Overall, the absence of any signal of light carbon from oxidation of organic matter in FA3 is consistent with the extremely low organic carbon contents of the rocks. The Wilsonbreen Formation dolocretes are interpreted as pedogenic primarily because the extremely high $\delta^{18} \mathrm{O}$ values would require ground surface conditions for such extremely effective evaporation to occur. As will be discussed later, this interpretation is also consistent with the vertical facies relationships.

The differentiated microstructures in Facies 3S are again typical of microbialites as are the distinctive surface textures (Fig. 10G; Callow et al., 2011). Such laminites are found in association with soils and intermittently flooded subaerial surfaces (Alonso-Zarza, 2003), although younger examples include root mats from higher plants that are clearly inapplicable here. Klappa (1979) ascribed cm-scale laminated deposits of 'hard pan' on calcretized limestone substrates as originating from the activities of lichen which colonize, bore into and form accretionary deposits on surfaces. The lichen-formed deposits exhibit features such as fenestrae, sediment incorporation and variable This article is protected by copyright. All rights reserved. 
crystal size which are consistent with the Wilsonbreen Formation example. However, no evidence of alteration of underlying cemented material has been found and the Wilsonbreen Formation microbial laminae are more distinct and are noticeably domed, in contrast with laminar calcretes. In fact, the microbial layering is indicative of active upward accretion, rather than slow pedogenetic alteration. Accretion occurred through both growth of carbonate-mineralized microbial mats and deposition of sand laminae. A shallow depression on a floodplain/playa margin is an apposite environment. A combination of a high water table from which evaporation could occur and very shallow water inundation followed by drying out and sediment addition, perhaps by aeolian action, is indicated. At Dracoisen (Fig. 9l), the gradational relationship between laminated carbonate and underlying chaotic breccia is a classic characteristic of evaporite dissolution breccias. The calcitecemented nature of the breccia is consistent with removal of one or more horizons of calcium sulphate evaporites either during deposition of the bed or soon afterwards following resumption of glacial conditions. Brasier (2011) presented a similar Mesoproterozoic example from Ontario in which stromatolites, associated with collapse breccias and calcretes, are inferred to form at a playa lake margin. Likewise, the modern McMurdo Dry Valleys contain a record of many shallow saline lakes and salt pans (Wilson, 1981).

Dolomite is known to precipitate as a primary phase or by replacement of a $\mathrm{CaCO}_{3}$ precursor in a range of surface environments (Warren, 2000), although the initial crystals (protodolomite) may lack well-developed ordering reflections, which increase during ageing (Gregg et al., 1992). The petrographic characteristics of FA3 dolomicrite are consistent with very early diagenetic replacement of a precursor carbonate or of primary growth of (proto)dolomite; the latter is clearly the case for zoned dolomicrospar cavity-linings (cf. Hood \& Wallace, 2012). The presence of euhedral crystals within displacive fabrics (Fig. 11C) is distinctive. Although Tandon \& Friend (1989) interpreted euhedral growth zones in displacive calcite in calcretes as evidence of recrystallization, it is more logically interpreted as a primary growth fabric, as argued by Spötl \& Wright (1992) in a dolocrete example.

This article is protected by copyright. All rights reserved. 
The extremely high $\delta^{18} \mathrm{O}$ values rule out post-depositional modification. Interpretation of the values as reflective of the depositional environment is also consistent with the trace element chemistry and preserved crystal growth zones. The high $\mathrm{Mn}$ content and absence of pyrite implies low $\mathrm{pO}_{2}$, but not anoxia, although the sulphate oxygen-isotope systematics are indicative of more redox variability than in Facies $2 \mathrm{~S}$. Specifically, bacterially mediated electron shuttling by $\mathrm{Mn}$-species can catalyze repeated transitions between sulphate and sulphite, which would erase any $\Delta^{17} \mathrm{O}$ anomaly and lead to high $\delta^{18} \mathrm{O}$ in sulphate (Bao et al., 2009). Such processes could trigger dolomite nucleation given the evidence from other field and experimental studies on the catalytic role of sulphate reduction (Vasconcelos et al., 2005; Zhang et al., 2012). The inferred redox variations may be related to a supply of brine primarily from within the sediment, contrasting with the surface waters from which Facies $2 S$ precipitated. The occurrence of the highest $\delta^{18} \mathrm{O}$ values in laminated dolomites of Facies $3 S$ is consistent with their formation by very near-surface evaporation, whereas abrupt variations in $\delta^{18} \mathrm{O}$ (Fig. 10J) imply occasional inundations by less evolved waters. In summary, FA3 provides examples of facies that stretch the boundaries of earth surface phenomena and indicate deposition in unusually arid terrestrial environments.

\section{Facies Association 4 (Facies 4I, 4R and 4S)}

Description

Facies $4 \mathrm{R}$ is the most common facies in this association and consists of rhythmic alternations of carbonate and sorted terrigenous sediment, which occur in association with structures implying shallow water to intermittently emergent conditions, such as wave ripple lamination and desiccation structures. The fine carbonate layers are usually dolomitic, or mixed dolomitic-calcitic, but include some limestone (Figs 7A and 12). The coarser sediment layers are universally composed of coarse silt to fine sand with evidence of tractional sorting, which distinguishes this facies association from FA5. Wherever laminae are sufficiently thick, undulatory cross-lamination is displayed (Fig. 13B) which

This article is protected by copyright. All rights reserved. 
can be confidently identified as wave-generated. Locally, symmetrical ripples are preserved in crosssection (Fig. 13A) or on bedding planes (Fig. 13C). Drying out is commonly indicated by desiccation structures with associated small intraclasts (Fig. 13B and H) or salt pseudomorphs (Fig. 13D), although such structures are not present in the majority of samples. Four examples of apparently non-evaporitic crystal pseudomorphs have been found, but these are much better developed in FA5 and are described in that section. Carbonate laminae are micritic in texture and typically uniform, although differentiated clotted microstructures also occur, similar to those described below in FA5, consistent with precipitation beneath benthic microbial mats (Riding, 2000). This facies was locally highly affected by subsequent glacitectonic deformation at the top of W2 at Ditlovtoppen, as described by Fleming et al. (2016).

The isotope traverse of Fig. 13J reveals a shift in isotopes from the sandy layers (with detrital dolomite) into dolomicrite implying that the latter is authigenic, as confirmed by $\mathrm{CL}$ observations (Fig. 14A and B). The limestone laminae in this facies association display a range of $\delta^{18} \mathrm{O}$ values from 11.9 to

$-3.2 \%$ with a mean of $-8.1 \%$, whereas dolomite layers range from -5.3 to $+1.4 \%$ with a mean of $1.9 \%$ (Fig. 6B). The difference of $6 \%$ in mean value, compared with inferred and observed differences of 2.6 to $3.0 \%$ for calcite and (proto)dolomite precipitating from equivalent fluids (Land, 1980; Vasconcelos et al., 2005) implies that the dolomites precipitated on average from waters with higher oxygen isotope values. The dolomites display covariance between $\delta^{13} \mathrm{C}$ and $\delta^{18} \mathrm{O}$ (Fig. 6B). Trace element data will be presented elsewhere, but FA4 and FA5 dolorhythmites also show a covariation of $\mathrm{Sr}$ (from 100 to $200 \mathrm{ppm}$ ) with $\delta^{18} \mathrm{O}$ and somewhat higher Sr values in calcites, and like other Wilsonbreen precipitated carbonates, they are Mn-rich (>1000 ppm).

Facies $4 \mathrm{I}$ occurs typically as discrete beds, normally 10 to $20 \mathrm{~cm}$ thick, of sharp based to erosionally based intraclastic sandstone with wave-generated lamination. The sand matrix is moderately sorted coarse silt to medium-grained sand and intraclasts are sometimes confined to the lower half of the bed. Several successive beds are shown in Fig. $13 \mathrm{H}$ in a section transitional upward This article is protected by copyright. All rights reserved. 
from Facies Association 5, and an example of this facies in thin section is illustrated in Fig. 13G. Two occurrences of ooids (Fig. 13E) have been found. At North Klofjellet, high in a generally poorly exposed W2 section, is a $1 \mathrm{~m}$ bed of indistinctly cross-laminated sands alternating with centimetrescale desiccated limestone beds containing scattered sand grains. This section is the lateral equivalent of fluvial facies (FA2) $1 \mathrm{~km}$ away at South Klofjellet. Ooids are found near the top of the unit, but make up less than $5 \%$ of the sand fraction. A range of cortices, from superficial coatings through to fully developed ooids with no visible core, is developed. Internal fabrics are micritic and microsparitic with a crude concentric structure. The mean oxygen isotope value of the limestone ( $>90$ wt. $\% \mathrm{CaCO}_{3}$ ) is $-7.6 \%$. The second occurrence of ooids is as a small proportion of the total grains within thin $(0.1 \mathrm{~m})$ cross-laminated green sandstone underlying FA5 sediments in member W3 at Ormen (Table 3).

Facies $4 \mathrm{~S}$ is represented by distinct sandstone beds in the Ditlovtoppen and Dracoisen sections. These sandstones are highly uniform, consisting of well-sorted fine-grained to mediumgrained sandstone, with very well-rounded grains. Bedding structures are confined to an indistinct, discontinuous parallel stratification. At Ditlovtoppen, this facies presents as a tabular $3 \mathrm{~m}$ thick bed spanning the $200 \mathrm{~m}$ width of the outcrop. Its lower few decimetres are locally thinly laminated sand and dolomite, changing laterally to uniform sandstone. Two thin beds of dolomite with floating grains are also found at the top of the unit. Grains range from very fine to coarse-grained, but most of the rock volume is composed of medium to coarse sand grains (Fig. 13F). The only sedimentary structure consistently displayed is an indistinct centimetre-scale horizontal lamination with slight variations in grain size, or locally with millimetre-scale laminae with silty dolomitic matrix. Locally the laminae are deformed into cusps, suggestive of upward fluid escape. Oxygen isotopes in several samples are slightly heavier than expected for detrital matrix, consistent with addition of precipitated dolomite. This bed transitions downward (Fig. 10H) to Facies $4 \mathrm{R}$ in which $\mathrm{mm}$ - $\mathrm{cm}$ scale sand laminae between rhythmic carbonates exhibit cross-lamination and wave-ripple morphology.

This article is protected by copyright. All rights reserved. 
Within 20 to $30 \mathrm{~cm}$ of the boundary, thin intraclastic flake breccias (Facies $4 \mathrm{I}$ ) and desiccation structures occur.

Interpretation

Facies $4 \mathrm{R}$ and $4 \mathrm{I}$ display evidence of sorting and reworking of the sediments by wave action. This indicates deposition in a water body that was unfrozen at the time of deposition of the coarser layers, which represent distinct time periods with more pronounced wave action. The sharp-based intraclastic beds (Facies 4I) appear to represent distinct storm events in which considerable disruption and transportation of cemented carbonate layers occurred, although at least in some cases these layers were already disrupted by desiccation.

The grains and structures in facies $4 \mathrm{R}$ and $4 \mathrm{I}$ are consistent with either a marine or a lacustrine origin, although no demonstrable tide-related phenomena are documented (cf. Fairchild \& Herrington, 1989). A quantitative description of wave climate (Allen, 1984) based on these structures is not possible, but no wave phenomena were seen requiring oceanic conditions. Although ooids are best known from marine environments and thick oolitic units were used as a criterion for warm climates in the Neoproterozoic context by Fairchild (1993), ooids have been described from Quaternary sediments reworked into Antarctic moraines (Rao et al., 1998) and also occur widely in various modern alkaline or hypersaline lakes. Lacustrine ooids form in water depths of 1 to $5 \mathrm{~m}$, with the best development in shallowest water. The Wilsonbreen Formation examples do not resemble hypersaline aragonite ooids with radial structure (e.g. Halley, 1977), consistent with their oxygen isotope composition unenriched in ${ }^{18} \mathrm{O}$. Ooids in smaller modern lakes tend to be superficial with relatively irregular outlines, whereas fully developed ooids are found on the shores of the large Lake Tanganyika in Burundi (Cohen \& Thouin 1987) corresponding to stronger wave action.

This article is protected by copyright. All rights reserved. 
Chemical arguments also favour a lacustrine origin for the carbonates; they probably arose as some combination of water column precipitates or within the sediment, for example as microbially influenced precipitates. Dolomite could be primary or, given the $\mathrm{CL}$ evidence, be a very early diagenetic replacement of $\mathrm{CaCO}_{3}$, although not one with high $\mathrm{Sr}$ content. Given the consistent Mn-enrichment, it is improbable that burial diagenetic recrystallization took place, making it more straightforward to interpret the stable isotope values as primary. The wide range of $\delta^{18} \mathrm{O}$ compositions is uncharacteristic of marine waters. For dolomites, the wide range of values cannot be explained by the relative small changes ( 1 to $2 \%$ ) that might be expected to accompany increased ordering from an initial protodolomite to an ordered dolomite (Gregg et al., 1992; Kaczmarek \& Sibley, 2014). However, the formation of dolomite from more ${ }^{18} \mathrm{O}$-rich, evaporated waters, is consistent with the standard paragenetic model in playa lakes (Dutkiewicz et al., 2000), although changes in source water composition as well as evaporation probably occurred.

The well-rounded sand grains found in Facies $4 \mathrm{~S}$ are consistent with aeolian transport as in the McMurdo Dry Valleys of Antarctica (Fig. 3C; Calkin \& Rutford, 1974; Hambrey \& Fitzsimons, 2010). However, grains with a long history of aeolian transport can be finally deposited in aeolian, fluvial or lacustrine settings. The good sorting, particularly of coarse laminae, instead point to tractional flows, but lack of cross-stratification rules out aeolian or subaqueous dunes. Hendy et al. (2000) developed the ice-conveyor model to account for sandy deposits on the floors of certain icecovered Antarctic lakes with floating glacier-ice margins. In this model, wind-blown sand melts its way through the ice in contrast to gravel which remains on the surface where it is transported by ice flow to the distal lake margins. The indistinct parallel stratification observed in this facies would develop in this context, but two features of the modern systems are not observed in the Ditlovtoppen occurrence: mounded bedding and upward gradation into coarse gravel (Hall et al., 2006). The Ditlovtoppen bed is tabular, whereas in the modern lakes sand transmission to the ice is focused, leading to mounds and ridges on the lake floor.

This article is protected by copyright. All rights reserved. 
A plausible alternative for Facies $4 \mathrm{I}$ is an inter-dune setting where wind ripple migration would be expected (Lancaster \& Teller, 1988). Ripple migration would give rise to translatent subhorizontal laminae, representing set boundaries, without internal ripple cross-lamination being preserved (Mountney \& Thompson, 2002). A water table that was at least seasonally high is required to account for dewatering structures and the precipitation of dolomite (incipient dolocrete). In such modern environments, seasonal flooding by surface water or emergent groundwater might occur, accounting for occasional dolomicrite laminae. The horizontal stratification is inconsistent with dune deposition, but is as expected on a sandflat or playa with a high water table, which fits with the transition to Facies $4 \mathrm{R}$ and $4 \mathrm{I}$ observed in Fig. $13 \mathrm{H}$.

Overall FA4 represents shallow-water and exposed sediments associated with a wavedominated shoreline and susceptible to wind-reworking. The balance of physical and chemical evidence favours a lacustrine coast setting.

\section{Facies Association 5 (Facies 5D and 5R)}

\section{Description}

This facies association is dominated by rhythmic alternations of carbonates and poorly sorted clastic sediment (Facies $5 R$ ). Locally, this facies grades into brecciated rhythmites which are distinguished as Facies 5D. Facies Association 5 is only a minor constituent of most of the W2 sections, although prominent in the South Klofjellet and Backlundtoppen-Kvitfjella Ridge (BAC) sections (Figs S5 and S6). However, it is the dominant carbonate-bearing facies association in member W3 where it alternates with ice-rafted diamictites of FA6.

Figure 15 illustrates variants of Facies 5R found in member W2. Figure 15A exhibits highly regular millimetre-scale alternations of limestone and wacke. The clastic sediment includes many microscopic diamictite pellets (arrowed) that are a normal feature found in this facies, whereas the small pseudomorphs crossing lamina boundaries are found more locally. Pebble-sized fragments in

This article is protected by copyright. All rights reserved. 
clastic layers (Fig. 15C and D) commonly display a dropstone texture associated with disruption of limestone laminae. An indicator of instability is shown by small-scale sedimentary growth faulting (Fig. 15C). Folds (Fig. 15F) demonstrate both some plasticity and fracturing of limestone, indicating partial cementation and syn- sedimentary deformation. Above these folds, the sediments are visibly disrupted and transitional to Facies 5D. The thickest example of facies 5D observed was a $0.4 \mathrm{~m}$ thick bed at Ditlovtoppen, containing both intraclastic and terrigenous sediment, and which disappears laterally within $100 \mathrm{~m}$. This bed clearly was derived by localized resedimentation of Facies 5R.

In member $\mathrm{W} 3$, Facies $5 \mathrm{R}$ is present as isolated beds up to $1 \mathrm{~m}$ thick exhibiting similar alternations of carbonate laminae and wacke/diamictite as in member W2 (Fig. 16). Figure 16A illustrates the base of one such bed with clear alternations of thick diamictite laminae and carbonate passing upward into more carbonate-dominated facies with only thin clastic laminae. The dominance of precipitated carbonate in this facies is shown in Fig. 16C, D and E, the latter being the sole example of precipitated carbonate in member W1. Disturbance by soft-sediment folding is nearly universal and the same combination of ductile and brittle behaviour of carbonate layers is shown (Fig. 16D and E) as in member W2. Figure 16B illustrates the development of a resedimented bed (Facies 5D) dominated by intraclasts, but with some poorly sorted sediment material, over a horizon with soft-sediment folds.

It is common for carbonate layers in Facies $5 \mathrm{R}$ to show irregular lamination or domal structures. Layers may be domed (Figs $15 \mathrm{C}$ and $16 \mathrm{C}$ ) up to centimetre-scale (Fig. 15F). Topography can be inherited from underlying layers (Figs 15F and 16C), and sometimes the base as well as the top of the layer is domed (Fig. 15C). Figure 15B displays both of these features in layers underlain by complex cement crusts with some remaining porosity. The crusts show neither botryoidal nor euhedral morphology and are composed of polycrystalline calcite mosaics in which each calcite shows the same zonation in CL. Some beds display only minor clastic debris (Fig. 15F) and there are even some more pure limestones with complex microstructures.

This article is protected by copyright. All rights reserved. 
Petrographically, carbonate laminae can be regularly (rhythmically) developed, millimetrescale in thickness. Laminae are often heterogeneous, and may be dolomitic, calcitic (Fig. 17A, B, D and F) or mixed mineralogy in composition (Fig. 17C). Where heterogeneous, laminae may show an increase in crystal size upward (Fig. 17A) or clotted textures of micrite within microspar. Under CL, both calcite and dolomite present coherent replacive fabrics (for example, Fig. 17F), in which crystals with identical zones grow throughout the fabric and enlarge into fenestrae. Rare examples of micritic rods around 10 to $20 \mu \mathrm{m}$ in diameter, with minor associated pyrite, are reminiscent of calcified sheaths such as found in the pre-Cryogenian Draken Formation in the study area (cf. Knoll et al., 1993), but are not as distinct. Millimetre-scale convexities on the upper bed surface are thrombolitic in texture (Riding, 2000) with irregular fenestrae (Fig. 17B). Clastic laminae tend to smooth the microtopography (Fig. 17A), whereas individual sand grains, dropstones or diamictite pellets can occur anywhere within the carbonate fabrics (Fig. 17D).

Trace element compositions of carbonate are similar to FA4. The limestone laminae in this facies association display a range of $\delta^{18} \mathrm{O}$ values from -5.6 to $-12.8 \%$ with a mean of $-9.2 \%$ and the $\delta^{13} \mathrm{C}$ values also display a large range from -2.1 to $+3.5 \%$. Although the full range in $\delta^{13} \mathrm{C}$ is shown by member W2, values in member W3 tend to be lower (Fig. 12). FA5 dolomite $\delta^{18} \mathrm{O}$ ranges from -10.3 to $+3.7 \%$, with a mean of $-3.2 \%$ (Fig. $6 \mathrm{~B}$ ) and covaries with $\delta^{13} \mathrm{C}$.

Common examples of crystal pseudomorphs occur in FA5, usually as subhedral to euhedral crystals, variably joined into confluent masses embedded within or apparently cutting across lamination (Fig. 18E, F and G). In some cases, trains of crystals are aligned along or concentrated within particular laminae. Size of individual crystals is similar within samples and ranges from 0.1 to $0.2 \mathrm{~mm}$ (Fig. 18F) to 1 to $3 \mathrm{~mm}$ (Figs 18B and 19A), the most common size being 0.5 to $1.0 \mathrm{~mm}$ (Figs $18 \mathrm{E}$ and $\mathrm{G})$. The range of cross-sections is dominated by four-sided or six-sided figures of crystals with equant to columnar habit. Pseudomorphs are equally likely to be developed in rhythmites with complex microstructures as in rhythmites with uniform micrite. Limestone hosts for pseudomorphs

This article is protected by copyright. All rights reserved. 
$(n=15)$ had a mean $\delta^{18}$ O composition of $-8.8 \%$ (range -6.2 to $-12.7 \%$ ) and dolomites likewise $(n=4)$ have a mean of $-1.92 \%$ (range -6.4 to $+1.7 \%$ ), similar to FA5 as a whole.

Although the within-sediment mode of occurrence is found in both members W2 and W3, the most spectacular, upward-growing crystals have only been seen at two levels in the South Klofjellet section of W3. A polished hand specimen (Fig. 19A) displays three distinct crystal horizons of which the upper two are shown in the photomicrograph of Fig. 18B. The crystals evidently grew freely upward and their terminations are draped by overlying sediment layers indicating that they formed at the sediment-water interface. They are variably draped by carbonate (Fig. 18B) or poorly sorted sediment (wacke or diamictite). In the latter case, crystal faces are variably corroded at the contact (Fig. 18B and D). Measurement of the internal crystal angles (equal to $180^{\circ}$ minus the apparent interfacial angle) in cut sections of this sample $(n=75)$ yielded two modes centred around 40 to $50^{\circ}$ and 90 to $110^{\circ}$ (Fig. 18C). Inspection of the crystal pseudomorphs which grew within sediment (Fig. 18E and G) is consistent with these results.

The pseudomorphs are typically preserved in the same mineral as the host carbonate, i.e. as dolomite or calcite. In some cases, the infilling phase is wholly cementing (Fig. 18E), whereas in others the variable internal fabrics point to a dominantly replacive origin (Fig. 18G). Such an origin is most evident for the upward-growing crystals where each is pseudomorphed in a mosaic of 20 to $100 \mu \mathrm{m}$ calcite crystals, which in stained thin section show a non-ferroan core and a ferroan periphery (Figs 17E and 18D).

\section{Interpretation}

The lack of size-sorting in FA5 sediments indicates that they were laid down in a water body lacking significant current activity, but on unstable slopes as suggested by the soft-sediment folds, interpreted as slump structures. All transitions occur from disturbed and slump-folded Facies $5 R$ to resedimented diamictites (Facies 5D, interpreted as debris flows) composed largely of Facies 5F blocks with some exotic clasts. The clastic sediment in Facies $5 \mathrm{R}$ is clearly glacially derived because it

This article is protected by copyright. All rights reserved. 
is invariably very poorly sorted, and contains diamictite pellets probably derived by ice rafting (till pellets) and local ice-rafted clasts (dropstones). Gravel is present in thicker laminae. Also FA5 transitions vertically into stratified diamictites interpreted by Fleming et al. (2016) as representing more continous deposition from floating ice. In contrast, no distinct fine-grained sediment-gravity flows were observed, implying lack of proximity to fluvial input to the water body. The carbonate laminae commonly display evidence (thrombolitic domal growth morphology and complex microstructures) of a microbial origin (Fairchild, 1991; Riding, 2000), including much evidence for in situ carbonate precipitation, coupled with incorporation of some siliciclastic sediment. A combination of photosynthesis and favourable nucleation of carbonate within extracellular polymeric substance and dead cellular material present in microbial mats may have promoted carbonate precipitation (Riding, 2000; Bosak \& Newman, 2003). However, in some cases, microbial structures are not apparent and carbonate laminae could be derived from settling of water-column precipitates.

The highly regular nature of the mm-scale carbonate-siliciclastic couplets, particularly in the thickness of the carbonate layers, is striking (Figs 15 and 16), and there are many modern and late Quaternary lacustrine analogues in which such couplets are annual, i.e. varves. Although there is no barrier to such sediments forming under marine conditions, photosynthesis raises carbonate saturation faster in low ionic strength waters than in seawater (Fairchild, 1991; Aloisi, 2008) and no modern marine analogues have been described. The dominant process creating carbonates in Alpine lakes is water-column photosynthesis from algal blooms (Kelts \& Hsü, 1978), and this mechanism has guided many interpretations of late Quaternary varves, allowing the succession of events through the year to be inferred (e.g. Neugebauer et al., 2012). However lakes vary greatly in their hydrology, internal structure, salinity and carbonate saturation state, leading to different patterns of carbonate production. For example carbonate mineral production may continue through to the autumn (Shanahan et al., 2008), or may partly depend on timing of input of ions from riverine input (Stockhecke et al., 2012). In some case, winter freezing conditions may control carbonate input This article is protected by copyright. All rights reserved. 
(Kalugin et al., 2013). Variations in redox conditions over time influence the preservation of varves in modern lakes, and in the case of the Gotland deep in the brackish Baltic Sea episodic oxygenation episodes may trigger a chain of events leading to characteristic Mn-carbonate layers superimposed on the annual pattern (Virtasolo et al., 2011). The absence of burrowing organisms in Cryogenian times led to continuous preservation of varve structure, but the Mn-chemistry of these carbonates is quite consistent (Fairchild et al., 1989; Bao et al., 2009) implying subdued redox fluctuations in the water body.

The crystal pseudomorphs also present important environmental evidence. The facies occurrence of these pseudomorphs argues against an evaporative origin. Although ${ }^{18} \mathrm{O}$-enriched dolomite samples indicates some evaporation, the oxygen isotope composition of most limestone and dolomites with pseudomorphs is typical for FA5 and lacks evidence for increased salinity, implying that the primary crystals were carbonates. The very regular mode of replacement by calcite with internal crystal-growth zonation (Fig. 17E) indicates that the precursor was more soluble than calcite, but still capable of forming euhedra, and hence was crystalline rather than amorphous. Vaterite and monohydrocalcite can be ruled out because they invariably form spherulites or microcrystalline precipitates (Dahl \& Buchardt, 2006; Pollock et al., 2006; Rodriguez-Blanco et al., 2014). Although aragonite typically forms mosaics of microcrystalline orthorhombic fibres, it is capable of forming radiating pseudo-hexagonal twinned 'ray' crystals of similar size to those seen in the present study (Fairchild et al., 1990, Riccioni et al., 1996). However, where six-sided crosssections are seen in the Wilsonbreen Formation (Fig. 16E), they are often elongated rather than equant, and the most elongated crystals in cross-section show a pair of terminating faces, not a basal pinacoid characteristic of aragonite. Strontium content of Wilsonbreen rhythmites is also low, whereas it is typically high in formerly aragonitic limestones (e.g. Fairchild et al., 1990).

Ikaite is a high-pressure phase, metastable at Earth surface conditions, but becomes relatively more stable at cold temperatures (Kawano et al., 2009), and nearly always forms naturally at cool temperatures $\left(-1.9\right.$ to $+7^{\circ} \mathrm{C}$, Huggett et al., 2005), on the sediment surface in spring-fed

This article is protected by copyright. All rights reserved. 
alkaline lakes and fjords and within marine sediment (Buchardt et al., 2001). It readily disintegrates to form calcite unless the solution contains an inhibitor for calcite precipitation. Bischoff et al. (1993) found that phosphate was most effective in this respect and indeed significant phosphate levels are typical of modern ikaite occurrences (Huggett et al., 2005; Selleck et al., 2007, Zhou et al., 2015). Ikaite is probably under-diagnosed as a primary phase (Shearman \& Smith, 1985; Bischoff et al., 1993; Buchardt et al., 2001) as borne out by new discoveries such as within sea ice (Fig. 19C, Nomura et al., 2013) and as millimetre-scale crystals in cold lakes (Fig. 19D and E; from the Patagonian Argentinian Laguna Potrok Alke, Oehlerich et al., 2013).

Ikaite is a monoclinic mineral that varies considerably in habit, from equant (Sekkal \& Zaoui, 2013) to elongate prismatic (Buchardt et al., 2001; Last et al., 2013) and the dominant crystallographic forms vary greatly, and may be stepped or curved (Shearman \& Smith, 1985), which make its positive identification from morphology difficult. Most of our knowledge comes from pseudomorphs, including the 'bipyramidal' aggregates of crystals known as glendonites (David et al., 1905; Fig. 18A), first found in shales associated with Permian glacial deposits and other cool-water environments and the 'thinolites' of Quaternary lakes of the western Great Basin, USA. The latter were detailed by Dana (1884) (Fig. 19B) and interpreted as ikaite pseudomorphs by Shearman \& Smith (1985) and Shearman et al. (1989). Swainson \& Hammond (2001) reinforced this identification following determination of refined lattice cell parameters of $a=8.8, b=8.3$ and $c=11.0 \AA$ with angle $\beta$ between ' $a$ ' and ' $c$ ' of $110^{\circ}$.

The pseudomorphs of the Wilsonbreen Formation are interpreted to represent a combination of forms. Prism and pinacoid forms meet at internal angles of $90^{\circ}$ and $110^{\circ}$ when cut at a high angle to the faces. This would account for the higher mode in the crystal angle distribution (Fig. 18C) and the common 'rhomb' shapes in section, similar to the crystals in Fig. 19C. Secondly the 30 to $60^{\circ}$ mode is interpreted to represent the junctions between prismatic faces such as those seen to terminate crystals in Figs 18A, 19B and 19E. It is notable that ikaite is only one-third as dense as calcite and so pseudomorphs in calcite would be expected to be initially highly porous even if the This article is protected by copyright. All rights reserved. 
$\mathrm{CaCO}_{3}$ was precipitated locally. This property is consistent with the styles of preservation observed (Fig. 16); Figs 17E and 18D compare well with examples in Larsen (1994), Huggett et al. (2005), Selleck et al. (2007) and Frank et al. (2008). An important corollary is that the replacive calcite mosaics more generally observed in FA5 (and FA4) limestones (Figs 15B and 17F) are also probably after ikaite.

Identification of presumably syngenetic ikaite replacement, and preservation of the crystal growth zones in $\mathrm{CL}$, supports the preservation of primary isotopic chemistry in FA5 (and FA4) carbonates. In the Wilsonbreen Formation as a whole, discussed above for FA2 and FA4, burial diagenetic calcite lacks $\mathrm{Mn}$-enrichment and has $\delta^{18} \mathrm{O}$ of $<-10 \%$. In FA5, the alternation with icerafted sediment implies temperatures consistently close to freezing. Hence, given the low $\delta^{18} \mathrm{O}$ signatures, the water body must have been fresh. Application of experimentally determined fractionation factors (Kim \& $\mathrm{O}^{\prime} \mathrm{Neil}, 1997$ ) extrapolated to $0^{\circ} \mathrm{C}$, indicates that water compositions on the VSMOW (Vienna Standard Mean Ocean Water) scale are approximately $2.7 \%$ higher than calcite compositions on the VPDB scale, i.e. -8.3 to $-15.5 \%$, and probably reflect mixing of different water sources. Dolomite facies have values on average $6 \%$ higher, implying formation from waters with higher salinity and higher mean Mg/Ca (Müller et al., 1972).

Many modern analogues for calcareous microbial laminae in cold lakes exist, including such extreme environments today as the ice-covered lakes of the McMurdo Dry Valleys of Antarctica (Parker et al., 1981) and reducing solution hollows beneath the Great Lakes (Voorhuis et al., 2012). One curious phenomenon is that of the thick cement crusts filling internal cavities found in both FA5 and FA2. A possible origin for these is the phenomenon observed in certain Antarctic lakes of the localized lifting of mats by gas generation (Parker et al., 1981). Early cementation of the mat would allow a more gradual fill of the resulting fenestrae as found in modern Antarctic lakes (Wharton et al., 1982).

This article is protected by copyright. All rights reserved. 
In respect of seasonality, many well-studied modern lakes show a turnover associated with cooling in winter and may have a frozen surface in that season. In this case, winter sedimentation is typically dominated by clay and organic matter (e.g. Lauterbach et al., 2011, Kalugin et al., 2013), but both these components are scarce in the Wilsonbreen Formation. In Antarctica, carbonate precipitation is linked to peak water column or microbial mat photosynthesis in late spring to early summer (e.g. Wharton et al., 1982; Lawrence \& Hendy, 1985), limited also by nutrient availability. Higher sediment input would be expected in the late summer to autumn when ice cover was at a minimum.

Work on Antarctic stromatolites offers further clues as to the relationship between different microbial fabrics in the Wilsonbreen Formation. The first major mat-former to be identified (Phormidium frigidum Fritsch) is known to be pre-adapted to cold environments and low light conditions (Parker et al., 1981) and tolerates conditions from fresh to saline and anoxic to oxygensaturated. Simmons et al., (1993) showed that this species is found not only in lakes, but also in glacial meltstreams, soils and cryoconite holes on ablated glacier surfaces, spanning the range of environments in which microbial deposits formed in the Wilsonbreen Formation. Voorhuis et al., (2012) found that a species of Phormidium also dominated the mat community at low oxygen levels in a 23 m deep Great Lakes sinkhole and demonstrated that species of this genus adapted to toleration or even utilize sulphide for anoxygenic photosynthesis. It is therefore probable that the Wilsonbreen Formation microbial communities were of low diversity, as expected for extremophiles, with specialized cyanobacterial species dominating the biota.

\section{Vertical and lateral facies relationships}

Vertical facies transitions can be used to establish whether sedimentary successions have the Markov property of being randomly stacked or whether they have predictably cyclic properties (Powers \& Easterling, 1982). A transition matrix derived from all the logged W2 sections (Fig. S7)

This article is protected by copyright. All rights reserved. 
demonstrates that there are vertical transitions between all of the facies associations, except FA1/FA7, which are only found bounding W2 and not within it. This pattern indicates a stochastic element to the facies accumulation, but there are clearly also preferred transitions. Although data are insufficient for formal statistical analysis, the relative number of transitions is a useful guide since total occurrences of each Facies Association are similar (Fig. 20). Two sets of the most common transitions concur with the interpretations made earlier. Firstly, fluvial channels (FA2) most commonly pass upward into floodplain sediments (FA3) and vice-versa. Such a close relationship would not be expected if FA2 was marine. Secondly, calcareous lake sediments (FA5) pass into FA6 (glacilacustrine) and vice-versa (and this is also the dominant pattern in member W3). This relationship emphasizes the transitional nature of change between major amounts of floating ice and reduction in ice sufficient to permit carbonate accumulation in microbial mats. Other transitions, such as those between ice-rafted sedimentation (FA6) and floodplain and lake-marginal sediments (FA3 and FA4), would require more sudden changes in lake level.

Regarding lateral relationships, overall, the Northeast Greenland - north-east Svalbard Neoproterozoic sedimentary basin is envisaged as elongate, with basement exposed in the far southwest of the Greenland sections and an overall NNE-SSW orientation (Fairchild \& Hambrey, 1995). Palaeocurrent data from Wilsonbreen Formation subglacial diamictites and associated grounded ice phenomena demonstrate glacier movement flow axially (to the NNE, Fleming et al., 2016). This sense of movement is consistent with the orientation of a thick grounding line fan in the Draocisen section (Fig.1 and Fleming et al., 2016). Within member W2, however, the facies mosaics do not illustrate this overall pattern so clearly. Figure 21 illustrates the cumulative thickness of each of the facies associations and demonstrates that there is no simple north-south spatial trend in facies within W2, except perhaps for the high incidence of fluvial facies (FA2) in the southernmost section. Such a complex facies mosaic implies that water and sediment are derived from multiple sources.

This article is protected by copyright. All rights reserved. 


\section{SIGNIFICANCE OF THE WILSBONBREEN FORMATION}

\section{Consistency of environmental conditions and climate}

In this section we assess whether the Wilsonbreen Formation environments can be considered as a coherent whole and hence be interpreted via modern analogues as a single climatic setting. The sedimentological evidence clearly points to syn-glacial carbonate deposition in FA5: ice-rafted sediment and ikaite formation. Facies $4 \mathrm{R}$ and $4 \mathrm{I}$ show similar types of carbonate accumulation, and localized dropstone deposition, but also evidence of reworking by waves in shallow water. FA3 evinces a hyperarid terrestrial environment that nevertheless borders accumulation of microbial tufas in streams with regularly fluctuating discharge (Facies 2S). Facies 4S evokes a landscape with significant aeolian sediment transport. All of these facies are consistent with a cold, arid terrestrial environment. It is notable also in the South Ormen section of member W3 that a dolocreted sandstone bed (FA3, Table 2) lies within a thick diamictites of FA6 (Table 2), indicating that the climatic aridity persisted, despite the dominance of deeper lakes with extensive ice-rafting within W3. All these facies have little resemblance to standard Neoproterozoic facies found between glaciations (Fairchild, 1993).

Other important evidence is provided by the sulphate isotope systematics (Bao et al., 2009; Benn et al., 2015), demonstrating that throughout deposition of all the carbonate facies in W2 and W3, atmospheric $\mathrm{PCO}_{2}$ was very high, in spite of glacial conditions. This paradox is explained by climate simulations of a Snowball Earth, that is, a planet that is experiencing extreme glaciation caused by runaway ice-albedo feedbacks and linked to $\mathrm{CO}_{2}$-hysteresis. Modelling clearly demonstrates that glaciation must be initiated at low $\mathrm{PCO}_{2}$ (0.1 to 1.0 mbar, Pierrehumbert et al., 2011) but can only be terminated at high $\mathrm{PCO}_{2}$ (>20 to 100 mbar, Benn et al., 2015). Modelling of continental environments with the Wilsonbreen case in mind demonstrates that at sufficiently high $\mathrm{PCO}_{2}$, precession forces glacial advances in one hemisphere whilst retreats occur in the other

This article is protected by copyright. All rights reserved. 
hemisphere (Benn et al., 2015). The climate remains uniformly cold, changing primarily in terms of the accumulation of snow and ablation of snow and ice. Because continental ice volume changes little, eustatic sea-level change would not be expected, but a large sea-level rise would occur at the end of Snowball Earth glaciation. Once warm, ice-free conditions were re-established, glacial conditions could not return without a necessarily slow (multi-million year) fall in $\mathrm{PCO}_{2}$ (Le Hir et al., 2009). Consequently, fluctuations between non-marine and marine conditions in the Wilsonbreen Formation are not anticipated unless there were local isostatic effects (and basin subsidence effects) strong enough to overcome the consequences of a fall in sea-level of several hundred metres (Creveling \& Mitrovica, 2015). A distinct marine transgression is clearly reflected in the basal part of the overlying Dracoisen Formation with a locally conglomeratic base passing up into stormdominated sediments and then offshore shales (Fairchild \& Hambrey, 1984; Halverson et al., 2004). The absence of such facies or other evidences of marine conditions in the Wilsonbreen Formation indicates that during its deposition isostatic depression by neighbouring ice sheets was much smaller than eustatic sea level fall due to build-up of ice (Benn et al., 2015). In summary, the Wilsonbreen facies consistently reflect a mosaic of arid terrestrial environments subjected to glacial advances and hence in principle can be calibrated against modern analogues as a single climatic-environmental system.

\section{Interpretation of stable isotopes and their covariation}

The interpretation of stable isotopes is simplified by several factors following from the above: (i) the same overall environment and climatic setting is represented throughout the period of carbonate deposition in the Wilsonreen Formation; (ii) stable minerals were formed either as primary primary precipitates or by early diagenetic replacement of other carbonates; and (iii) the possible impact of variation in depositional temperature, or minor post-depositional exchange, are small compared with the very wide range of $\delta^{18} \mathrm{O}$ values. Hence the stable isotope data can be taken as direct

This article is protected by copyright. All rights reserved. 
indicators of depositional conditions and the variation in $\delta^{18} \mathrm{O}$ in carbonates interpreted to reflect that of the depositional waters (Fig. 22). The $\delta^{13} \mathrm{C}$ signature is linked to acquisition of carbon from bedrock and oxidation of organic sources and variable equilibration with atmospheric carbon dioxide, whereas variability in $\delta^{18} \mathrm{O}$ is interpreted as due to differing snow and ice compositions and mixing of resultant meltwaters, coupled with evaporation. The interpretation herein (Fig. 22) is aided by observation of modern processes in the McMurdo Dry Valleys and other cold settings.

A potential organic source in the Dry Valleys is the periodic flushing of cryoconite holes on the glacier surface, which provide nutrients for ephemeral streams and lake basins (Bagshaw et al., 2013). Addition of respired carbon from this source can be seen in the chemistry of some streams with $\delta^{13} \mathrm{C}$ values as light as $-9.4 \%$ (Lyons et al., 2013). Most Dry Valley stream values are -3 to $+2 \%$, possibly reflecting carbon contribution from a carbonate source rock (cf. Leng \& Marshall, 2004) and ranging up to $+5 \%$, which Lyons et al. (2013) attributed qualitatively to progressive equilibration with atmospheric $\mathrm{CO}_{2}$. Chemical equilibration between atmospheric $\mathrm{CO}_{2}$ and an Alpine meltstream was shown to be attained within a few hundred metres of flow (Fairchild et al., 1999), although this situation falls short of isotopic equilibration, requiring more extensive exchange until the large gaseous source of carbon dominates (Fairchild \& Baker, 2012, chapter 5). In Dry Valley lakes, more efficient processes for modifying $\delta^{13} \mathrm{C}$ are found: vertical trends caused by water-column photosynthesis at shallow depths (leading to positive values of $\delta^{13} \mathrm{C}$ ), organic matter oxidation (causing a decrease in $\delta^{13} \mathrm{C}$ with depth), and local methanogenesis (releasing $\mathrm{CO}_{2}$ with complementary high $\delta^{13} \mathrm{C}$ values at depth) have been described (Lawrence \& Hendy, 1985; Neumann et al., 2004). Cold lakes in other settings can sometimes develop very low $\delta^{13} \mathrm{C}$ values through release of methane from solid hydrates (Propenko \& Williams, 2005).

Gooseff et al. (2006) summarized data on $\delta^{18} \mathrm{O}$ variation for glacier ice, snow, streams and lakes in the Dry Valleys, although interpretation was complicated by strong inter-annual variations. In Taylor Valley the mean composition of glacier ice in each sub-basin feeding a specific lake varied This article is protected by copyright. All rights reserved. 
from -21 to $-33 \%$ and some samples were as light as $-45 \%$. Stream samples varied from -42 to $22 \%$ and lay close to the meteoric-water line up to $-32 \%$, but diverged from it at higher values, reflecting the consequences of evaporation in streams longer than $2 \mathrm{~km}$. In addition to simple surface evaporation, mixing with isotopically heavy shallow subsurface (hyporheic) water was also a factor, indicative of the effectiveness of evaporation of subsurface water at a shallow water table. Further isotope fractionation occurs where water resides longer in saline lakes. Matsubaya et al. (1979) measured and modelled the ${ }^{18} \mathrm{O}$-enrichments in the most saline ponds in the Dry Valley area and found up to $20 \%$ higher values in the unfrozen Don Juan Pond and the east lobe of Lake Bonney compared with the source. Likewise, Nakai et al. (1975) documented a 23\%o variation in $\delta^{18} \mathrm{O}$ composition of calcites with the highest values representing evaporative deposits on land surfaces. Such pronounced ${ }^{18} \mathrm{O}$-enrichments along streamcourses, and the ca. $20 \%$ ototal variation, are only permitted because of the meteorological factors leading to persistently low relative humidities of 50 to $60 \%$.

For the ancient carbonates, it is useful to consider the presence or absence of covariance of $\delta^{18} \mathrm{O}$ and $\delta^{13} \mathrm{C}$ (Figs 7 and 23). Talbot (1990) compiled data from a variety of modern and ancient lakes and found that a lack of isotopic covariation is typical of open lakes in which controlling factors for the variation in the two isotopes are decoupled. This is typical of the limestones of FA4 and FA5 (Figs 7B and 23). Conversely, covarying trends in lacustrine carbonates (as in FA4 and FA5 dolomites) were identified as a characteristic feature of closed lakes and reflected a combination of evaporation to cause increase in $\delta^{18} \mathrm{O}$, and residence time, permitting equilibration with atmospheric $\mathrm{CO}_{2}$ as a first-order control on ultimate $\delta^{13} \mathrm{C}$ values. Although $\delta^{13} \mathrm{C}$ and $\delta^{18} \mathrm{O}$ data on Antarctic streams (Gooseff et al., 1006; Lyons et al., 2013) was obtained separately and so cross-plots are not available, these environments too can be anticipated to display covariation. The slopes of covariation in the Talbot (1990) data were found to be quite varied, with lower slopes interpreted as reflecting broad, shallow lakes in which evaporation would play a more prominent role. The data were primarily from limestone and water-column precipitates, although examples were shown

This article is protected by copyright. All rights reserved. 
where benthic carbonate and dolomites fitted the trends. Apart from attaining high absolute values for $\delta^{18} \mathrm{O}$ in $\mathrm{FA} 3$, the Wilsonbreen Formation carbonates show covarying slopes and ranges within those presented by Talbot (1990), providing a confirmation that the evaporation-equilibration explanation for data trends is reasonable.

Now the $\delta^{13} \mathrm{C}$ values are interpreted: both where covariations are absent and at the starting points for covariation. The initial carbon isotope composition of a glacial meltstream may not reflect any atmospheric influence because many meltwaters derive from ice with low air content and have $\mathrm{PCO}_{2}$ values well below atmospheric (Fairchild et al., 1994). The mean $\delta^{13} \mathrm{C}$ of detrital dolomite in the Wilsonbreen Formation is $+2.4 \%$ (Fig. $6 \mathrm{~A})$, but with significant local variations $( \pm 1.3 \%$ ) and additional uncertainty because limestone appears to have preferentially dissolved from the matrix. A combination of moderately positive $\delta^{13} \mathrm{C}$ from detritus and negative $\delta^{13} \mathrm{C}$ values of organic carbon could have fixed the starting $\delta^{13} \mathrm{C}$ value of around $+1 \%$ o for the FA2 fluvial facies covarying trend. The higher starting point for FA3 reflects the more evolved nature of these floodplain surface fluids, which consistently formed dolomite. In contrast, the trend for FA4 and FA5 lacustrine dolomites starts at lower values of 0 to $+1 \%$, within the range of limestones. Carbon isotope signatures $<+1 \%$, that is lower than those in fluvial facies, presumably reflects addition of carbon from an organic source, but overall variations are not large enough to suggest a role for methanogenesis. In the open lakes characterized by lack of isotope covariation (FA4 and FA5 calcite), the higher $\delta^{13} \mathrm{C}$ values could reflect either the effects of photosynthesis or greater $\mathrm{CO}_{2}$-equilibration, without evaporation. The most extreme high $\delta^{13} \mathrm{C}$-low $\delta^{18} \mathrm{O}$ limestones in FA4 are from member W3 (Fig. 12); these are intraclastic breccias implying possible exposure, which would have aided atmospheric equilibration. No difference is noted between obviously microbial and other limestones, a common pattern in the Neoproterozoic (Fairchild, 1991). Low $\delta^{13} \mathrm{C}$ values occur in each studied section and are almost always stratigraphically close to values that are much higher, possibly indicative of changing lake levels. The FA5 sediments from $\mathrm{W} 3$ all have relatively low $\delta^{13} \mathrm{C}$ values which might reflect a relatively

This article is protected by copyright. All rights reserved. 
deep water setting, consistent with the dominance of ice-rafted sedimentation in this member in the southern sections and the universal disruption of FA5 sediments by slumping.

Now the theoretical $\delta^{13} \mathrm{C}$ end-point resulting from equilibration is considered. Carbonate precipitated from a solution in isotopic equilibrium with atmospheric $\mathrm{CO}_{2}$ is expected to display $\delta^{13} \mathrm{C}$ values heavier than the atmosphere by $10.4 \%$ at $0^{\circ} \mathrm{C}$ (falling to $9.1 \%$ at $20^{\circ} \mathrm{C}$ ), as calibrated by the experimental work of Mook et al. (1974). The long-term ( $>10^{8}$ year) $\delta^{13} \mathrm{C}$ composition of the atmosphere should show variation largely in parallel with ocean water with which it tends to equilibrate, and ocean water in turn has a composition constrained by the proportional burial of isotopically light organic carbon. As a result, short-term variations can be expected because of flux variabilities, as demonstrated by direct measurement of past (pre-industrial Holocene) atmospheres from ice cores showing a range from -6.3 to $-6.6 \%$ (Elsig et al., 2009). A further mass-balance constraint is the bulk Earth mean composition of carbon (Berner, 2004). The latter can be estimated from mantle and meteorite samples as around $-7 \%$, but volcanic gases are typically somewhat heavier (Javoy et al., 1986). An atmosphere with a composition around -6\%o would be in equilibrium at zero degrees with carbonates around $+4.4 \%$.

The carbon dioxide level in the Snowball Earth atmosphere should have progressively risen because of sustained input from volcanic sources and limited removal, mainly by dissolution in the ocean wherever gaps in the ice cover occurred (Le Hir et al., 2008). The limited opportunities for back-exchange from the oceans imply that the atmosphere should have provided a good sample of the carbon isotope composition of volcanic emissions. For the W2 data, each of the facies association fields (Figs 12 and 23) tops out at around 3.5 to $4.5 \%$ which is close to the expected values for equilibration with the atmosphere dominated by volcanic emissions as discussed above. Member W3 dolocretes have $\delta^{13} \mathrm{C}$ values $1 \%$ higher than considered so far (Fig. 12), but this difference is difficult to interpret without an overall data trend. One possibility is that there is a local contribution by freezing, which Lyons et al. (2013) invoked to explain $\delta^{13} \mathrm{C}$ values in the range +5 to $+12 \%$ on carbonate-encrusted rocks on the land surface of Dry Valley.

This article is protected by copyright. All rights reserved. 
Equilibration would have been aided by evaporation, the extent of which can be deduced from $\delta^{18} \mathrm{O}$ data. In FA2 limestones, the range of $\delta^{18} \mathrm{O}$ is rather less than observed in the Dry Valley streams; both evaporation and variation in source water composition may be responsible for the variation in these compositions. Similar remarks apply to the dolomites of FA4 and FA5, although largely open lacustrine environments such as these are not found in the Dry Valleys. However, evaporation is clearly a powerful agent for FA3 and the slope of isotope covariation is lower, consistent with a surficial origin leading to more efficient evaporation (Talbot, 1990). Allowing for a 3\%o offset between dolomite and calcite (Land, 1980), the evaporative trend (Figs 7B and 12) extends beyond the composition of fluvial limestones by a further $11 \%$ for dolocretes (Facies 3D) and $15 \%$ for stromatolitic laminites (Facies 3S). Evaporation of coastal seawater, under typical high humidity conditions would cause an increase in $\delta^{18} \mathrm{O}$ of at most $6 \%$, whereas a $17 \%$ increase from a $-10 \%$ starting point was observed in a freshwater Texan pond under conditions of less than $50 \%$ humidity (Lloyd, 1966). The extreme enrichments in FA3 stromatolitic crusts, require similarly low humidities to this example and the Dry Valleys, and could only be possible for facies developed at the land surface.

The FA4 and FA5 lacustrine calcites have lower $\delta^{18} \mathrm{O}$ compositions than those of FA2 fluvial limestones. By analogy with modern environments, this probably reflects a local, low altitude source of water for FA2, whereas the variability in $\delta^{18} \mathrm{O}$ within FA4 and FA5 could reflect varying meltwater sources, including large glaciers with low $\delta^{18} \mathrm{O}$. The range of $\delta^{18} \mathrm{O}$ is actually rather less in FA2 than in the Dry Valley streams and given that the values are typically heavier than the lakes, a relatively local, low-altitude source for meltwater is implied. For the Carbonate Lake Margin FA4, the $\delta^{18} \mathrm{O}$ values are similar to Carbonate Lake FA5 and there is a lack of isotopic covariation with both sets of data. This would imply an open lake (Talbot, 1990), but care is needed with such an interpretation because the data represent several different lakes that formed successively. As derived earlier, the range of $\delta^{18} \mathrm{O}_{\text {water }}$ values implied from calcite precipitation at $0^{\circ} \mathrm{C}$ is around -8.5 to $-15.5 \%$ on the

This article is protected by copyright. All rights reserved. 
VSMOW scale. This range might be explained by variable mixing of local snow, local glacier ice and melt from larger or higher glaciers, by analogy with the Dry Valley region.

The ultimate driver for Rayleigh fractionation in the atmosphere, which leads to ${ }^{18} \mathrm{O}$ depleted values in atmospheric precipitation, is partial condensation and removal of vapour as a result of a fall in temperature of the air mass. Inferred Wilsonbreen meltwater $\delta^{18} \mathrm{O}$ values higher than those in the modern Dry Valleys implies a lesser degree of fractionation, as originally noted by Fairchild et al. (1989). A comparable modern glacial area for the Wilsonbreen in terms of $\delta^{18} O$ is the Vatnajökull ice cap of Iceland below which Robinson et al. (2009) found a representative ice- and snowmelt composition of $-12 \%$. Note that indirect evidence for more isotopically light Neoproterozoic meltwater has been found in two records from South China (Zhao \& Zheng, 2010; Peng et al., 2013), although these do not necessarily relate to a panglacial and in the former case is a younger, Ediacaran glaciation. A more pertinent record is that of Kennedy et al. (2008) in calcitecemented Marinoan tidal siltstones of South Australia where calcite as light as $-25 \%$ was analyzed, and interpreted to reflect input of meltwater from highly fractionated low-latitude ice sheets, although there may be other possible interpretations of these data bearing in mind the possible decomposition of clathrates at this site. In summary, the distinctively heavy isotopic signature of Wilsonbreen meltwater may be a characteristic feature of low-latitude glaciation which should prompt future studies by an isotope-enabled general circulation model.

\section{Similarities and differences with the McMurdo Dry Valleys}

The Wilsonbreen Formation represents a small part of a largely marine depositional basin-fill many kilometres thick, deposited over 300 Myr. The outcrop belt is orientated NNE-SSW, and the original basin may have been an intracratonic rift with a similar trend (Cawood et al., 2007) leading to the tabular nature of the Formation from north to south. The Dry Valleys region occupies a hinge

This article is protected by copyright. All rights reserved. 
between the uplifting Transantarctic Mountains and the rift-related subsidence subsiding of McMurdo Sound and Ross Sea (Etienne et al., 2007). Hence, both the ancient and modern basins have the capacity for long-term sediment accumulation, but on the short-term, rates of erosion and deposition will be hghly dependent on local geomorphic changes. Local topographic controls for the Wilsonbreen Formation, for example from lateral basin margins, are unknown.

The long-term record of the McMurdo Dry Valleys shows a progression from temperate ice in the early Cenozoic through to the cold, arid conditions that have held since the Pliocence (McElvey, 1979; Barrett \& Hambrey, 1992), associated with cold-based local glaciers. The Dry Valleys have been subject to out-of-phase advances of Taylor Glacier, an outlet glacier from the EAIS and encroachment of the West Antarctic Ice Sheet from the Ross Sea. In contrast, it appears that the Wilsonbreen Formation was remote from any marine influence because of the extreme eustatic sealevel fall in the late Cryogenian. The subglacial phenomena (FA1) clearly require warm-based glaciers as does the deposition of the thick waterlain diamictites of FA6 (Fleming et al., 2016). The complex facies interstratifications, even in members W1 and W3, imply a greater dynamism of Wilsonbreen Formation environments than those experienced in the recent history of the Dry Valleys. Nevertheless, in both cases, ice-damming is required to permit deep lakes to form, later to be replaced by exposed conditions. Such externally imposed changes in lake level or glacial advances and retreats would be superimposed on any intrinsic tendency for facies migration and are the most probable reason for the myriad vertical facies transitions and complex lateral geometries in the Wilsonbreen Formation. As argued above, the shifts in depositional style between members W1, W2 and W3 are probably a primary function of mean lake level rather than representing a fundamental change in climate or regional palaeogeography.

The high palaeolatitudes of the Dry Valleys ensures a high seasonality of temperature such that meltwater production is limited to a couple of months in summer. The Wilsonbreen Formation is thought to have lain in the sub-tropics (Li et al., 2013) where seasonality today primarily relates to moisture balance. This also applies in the late stages of a Snowball Earth, since general circulation

This article is protected by copyright. All rights reserved. 
modelling indicates that alternating seasons in which precipitation exceeds ablation in the summer and vice-versa in the winter would have been a strong feature of the climate in latitudes 20 to $30^{\circ}$ from the equator (Benn et al., 2015). The Snowball climate also has greatly enhanced diurnal and annual temperature variability at a given latitude compared with that of today (Pierrehumbert, 2005) since temperature responds directly to insolation, with less effective smoothing than today by lateral latent heat transport by moisture. The implications remain to be fully explored, but Benn et al. (2015) presented an indicative plot (their fig. S15) demonstrating that, in the month of April, although mean temperatures remain below zero, lowland areas in the tropics and sub-tropics should experience a significant number of positive degree days when melting can occur. The overall effect is that, open water in Wilsonbreen lakes was clearly extensive, at least seasonally.

This difference implies that there is no necessity for a permanent ice cover in Wilsonbreen formation lakes and indeed the open water structures of FA4 and the extensive ice-rafting in FA5 and FA6 clearly shows this to be lacking. Hence the mean annual temperature of the Wilsonbreen environment was presumably higher than the $c a-20^{\circ} \mathrm{C}$ of the Dry Valleys. Nevertheless, a remarkable similarity is found in the range of oxygen isotope values. The initial isotope values of meltwater in Wilsonbreen times were more typical of modern sub-Arctic rather than polar regions, but this is argued to be caused by the peculiar conditions of Rayleigh fractionation in a warm atmosphere above ice sheets. The wide range caused by evaporation is comparable, caused by extreme evaporation driven by unusually low humidity.

Another latitude-related factor is the relative sensitivity to climatic change related to orbital forcing. Whilst the Dry Valley region is susceptible to facies changes related to subtle environmental changes on inter-annual to multimillennial scales, the most significant environmental changes related to glacial advances and retreats are on orbital (obliquity and eccentricity) timescales (Hendy 1980). The slowly depositing Elbobreen Formation, which underlies the Wilsonbreen Formation, shows the influence of orbital forcing in the development of 200 regular cycles in offshore marine sediments (Fairchild et al., 2016). In the Wilsonbreen Formation, Fig. 1 illustrates about ten intervals

This article is protected by copyright. All rights reserved. 
of cessation of glacial deposition, with uncertainties because of the thin and lensing (possibly eroded) intervals in W3 in particular. Accumulation rates of annually laminated carbonate facies, both fluvially (FA2) and in lakes (FA4/FA5) is of the order of $1 \mathrm{~mm} /$ year: hence such retreat phases represent minimum periods of $10^{3}$ to $10^{4}$ years since periods of non-deposition, due to lack of local accommodation space or sediment supply, are probable. Such timescales are approaching the present-day Milankovitch scale of climatic fluctuation, an observation which stimulated the modelling of precessional cycles in Benn et al. (2015). The effect of such cycles is to cause mirrored interhemispheric differences in ablation and accumulation linked to aridity/humidity, rather than significant temperature change. This is analogous to the modern Antarctic environment except that forcing on precessional timescales is a feature of low-latitude systems. Given that ca $20 \mathrm{kyr}$ precession is greatly enhanced during higher eccentricity (on the 100 kyr timescale), the suggested interpretation of members W2 and W3 here is that they represent one or two eccentricity cycles, within each of which several precession-related fluctuations are recorded. Although this interpretation is plausible rather than demonstrable, the two basin-wide advances and retreats of terrestrial ice in the centre of the Wilsonbreen Formation (Fig. 1) provide strong evidence for major, orbitally forced facies change.

A final point of comparison is the carbonate mineralogy. Modern Antarctica has very little carbonate bedrock, but alkalinity is generated both by carbonate and silicate weathering, permitting carbonate precipitation, particularly in lakes, controlled by seasonal photosynthesis. By contrast, the Wilsonbreen Formation reflects the erosion of carbonate-rich catchments and calcite precipitation is recognized also in streams. Although limestone makes up $20 \%$ of the gravel fraction, dolomite is the only carbonate in the fine fraction of detritus because of preferential calcite dissolution, implying that unmodified molar $\mathrm{Mg} / \mathrm{Ca}$ ratios will on average be less than one, although they will increase as calcite is reprecipitated within the basin. Data from streams and most lakes in the Dry Valleys also have $\mathrm{Mg} / \mathrm{Ca}$ less than one, although extensive $\mathrm{CaCO}_{3}$ precipitation in Lake Fryxell leads to enhanced $\mathrm{Mg} / \mathrm{Ca}$ (Green et al., 1988) and presumably such waters were responsible for precipitation of

This article is protected by copyright. All rights reserved. 
aragonite in many late Quaternary lakes (Hendy, 1979). Rather than aragonite, ikaite is recognized as a precursor to calcite in the Wilsonbreen case. As noted earlier, modern examples of ikaite formation are associated with high aqueous phosphate, which inhibits calcite precipitation and yet modern Antarctic lakes are oligotrophic. However, phosphate fluxes should be enhanced by glacial erosion in most cases and Planavsky et al. (2010) argued for a glacially induced nutrient surplus following Neoproterozoic ice ages. However, Burton (1993) stressed that there are a wide range of aqueous inhibitors for calcite precipitation. A circum-neutral pH would be expected in Wilsonbreen waters because of high atmospheric $\mathrm{PCO}_{2}$. This has the effect of increasing the ratio of $\mathrm{HPO}_{4}{ }^{2-}$ to $\mathrm{PO}_{4}{ }^{3-}$ thus strengthening the phosphate-inhibition effect on calcite. The effect is also accentuated by high sulphate (Burton, 1993) which is exceptionally high in Wilsonbreen carbonates (Bao et al., 2009). Modern dolomite has not yet been recognized in Antarctica, yet it is common in the Wilsonbreen facies, apparently aided by factors such as evaporation and fluctuating redox, and possibly also the widespread occurrence of dolomite rock flour as nuclei.

\section{CONCLUSIONS}

1. Carbonate in the Wilsonbreen Formation confirms the non-marine environment of deposition in a glaciated basin supplied with debris from erosion of platform carbonates. The consistently dolomitic nature of the detrital matrix of Wilsonbreen Formation sediments contrasts with the common presence of limestone in coarser debris and demonstrates the preferential dissolution of calcite over dolomite. Carbonate-rich meltwaters were thus able to precipitate $\mathrm{CaCO}_{3}$ once supersaturation was achieved by processes such as photosynthesis or evaporation.

2. Evidence from physical sedimentary structures allows four facies associations to be distinguished in which carbonate was precipitated, distinct from three facies associations dominated by glacial and periglacial processes. The Fluvial Channel Facies Association (Facies Association 2; FA2) commonly contains microbial limestone laminae with millimetre-scale lamination and notable syn-

This article is protected by copyright. All rights reserved. 
depositional radiaxial calcite cements; these compare physically with modern microbial mats in ephemeral Antarctic streams. The Dolomitic Floodplain Facies Association (Facies Association 3; FA3) consists of soil zone/playa surficial dolocretes and dolomitic stromatolites in which dolomite was probably a primary precipitate. The Carbonate Lake Margin Facies Association (Facies Association 4; FA4) typically displays micritic and locally microbial laminae interlaminated with wave-sorted silts and sands with local development of intraclastic breccias. Finally, the Carbonate Lake Facies Association (Facies Association 5; FA5) displays millimetre-scale (varved) alternations of micritic carbonate or laminated microbial carbonate (including microsparitic and fenestral laminae) with poorly sorted sediment containing recognizable ice-rafted debris. Locally in member W2, and pervasively in member W3, partly lithified sediments were disturbed by slump folding and locally transformed to carbonate-rich debris flows.

3. In both FA4 and FA5, there are textural indicators of mineralogical replacements. Dolomite can be seen to replace $\mathrm{CaCO}_{3}$ precursor. Although some calcite is likely to be primary, calcite pseudomorphs after ikaite $\left(\mathrm{CaCO}_{3} \cdot 6 \mathrm{H}_{2} \mathrm{O}\right)$ are common. The ikaite formed individual crystals within the sediment, formed crusts which grew centripetally into pores, and locally grew upward at the sediment-water interface. This paragenesis is now becoming better known in modern cold lakes.

4. Stable isotope data demonstrate that carbonates in the different facies associations form distinct fields that are all interpreted as consistent with primary depositional conditions. Limestones in FA4 and FA5 lack $\delta^{13} \mathrm{C}-\delta^{18} \mathrm{O}$ covariation and were primarily influenced by mixing of meltwater sources, the variable addition of light carbon from organic decomposition, and some re-equilibration with the atmosphere. Other sub-sets demonstrate covariation, interpreted as a combination of evaporation and equilibration with the atmosphere. This allows the $\delta^{13} \mathrm{C}$ composition of $\mathrm{CO}_{2}$ released from volcanism during the glaciation to be constrained to -6 to $-7 \%$. Direct evidence of primary fluid compositions is unavailable because of secondary fluid migration into inclusions, despite the presence of primary trace element growth zones. Nevertheless, the very wide range of $\delta^{18} \mathrm{O}$ values must be primarily related to changes in water composition, given the consistently cool

This article is protected by copyright. All rights reserved. 
depositional conditions. The exceptionally high $\delta^{18} \mathrm{O}$ signatures of FA3 dolomites, up to $+14.7 \%_{\text {ovPB }}$, attest to the hyperaridity of the environments. Conversely, the inferred $\delta^{18} \mathrm{O}$ compositions of the input meltwaters ( -8 to $-15 \%$ vsmow) are more comparable to modern Iceland than to present-day polar regions. This is likely to reflect relatively limited Rayleigh fractionation in the atmosphere, because of its relative warmth, linked to enhanced absorption of infra-red radiation from high $\mathrm{CO}_{2}$ levels.

5. Although preferred vertical facies transitions occur, there is no development overall of multi-facies cyclicity. The strong isotopic covariations associated with closed lakes and streams, and rhythmic carbonate laminae are strong motifs of non-marine facies. In these environments, the landscape was repeatedly transformed by damming and draining of lakes as the glaciers advanced and retreated. In turn, these are likely to have represented amplified geomorphic responses to subtle climatic shifts in a persistently hyper-arid setting, for which the McMurdo Dry Valleys provide a rich modern analogue. Although Wilsonbreen lakes were not perennially ice-covered as in the modern environment, many points of similarity between the modern Antarctic and the ancient environments have been drawn in this study, specifically including the rates and styles of sediment deposition, biogeochemistry, and extreme ${ }^{18} \mathrm{O}$-enrichment related to the hyperarid climate.

6. The carbonates of the Wilsonbreen Formation are distinctive and include unique facies and record-breaking isotope compositions. They represent, along with interbedded diamictites, the complex environmental response to changing rates of accumulation and ablation of snow and ice, likely to have been forced by a series of precessional cycles late in the evolution of a Snowball Earth.

\section{ACKNOWLEDGEMENTS}

The fieldwork and subsequent analyses were funded by Natural Environment Research Council grant GR3/ NE/H004963/1 within project GAINS (Glacial Activity In Neoproterozoic Svalbard). We are grateful to the Norwegian authorities in Svalbard and the logistical department of the University in

This article is protected by copyright. All rights reserved. 
Svalbard in facilitating our fieldwork, and other members of the GAINS team for their collegiality and scientific zest. The senior author records his personal appreciation to Paul Hoffman for his inspiration, and support for this project at a critical stage, to Martin Kennedy for his friendship, and rigorously critical feedback on Neoproterozoic data and ideas, and to Tony Spencer for his insight, and careful editorial comments on a draft. Journal referees, including Alex Brasier and Kristin Bergmann, gave invaluable advice leading to significant improvements in the paper.

\section{REFERENCES}

Abbott, D.S., Voigt, A. and Koll, D. (2011) The Jormungand global climate state and implications for Neoproterozoic glaciations. J.Geophys. Res., 116, D18103, doi:10.1029/2011JD015927.

Allen, P.A. (1984) Reconstruction of ancient sea conditions with an example from the Swiss Molasse. Mar. Geol., 60, 455-473.

Allen, P.A. (2015) Snowball climate conundrum/ nature Geoscience | ADVANCE OnLINE PUblication 24/8/15.

Allen, P.A. and Etienne, J.L. (2008) Sedimentary challenge to Snowball Earth. Nat. Geosci., 1, 817825.

Aloisi, G. (2008) The calcium carbonate saturation state in cyanobacterial mats throughout Earth's history. Geochim. Cosmochim. Acta, 72, 6037-6060.

Alonso-Zarza, A.M. (2003) Palaeoenvironmental significance of palustrine carbonates and calcretes in the geological record. Earth-Sci. Rev., 60, 261-298.

Andrews, J.E. (2006) Palaeoclimatic records from stable isotopes in riverine tufas: Synthesis and review. Earth-Sci. Rev., 75, 85-104.

Andrews, J.E. and Brasier, A.T. (2005) Seasonal records of climate change in annually laminated tufas: short review and future prospects. J. Quat. Sci., 20, $411-421$.

Arnaud, E., Halverson, G. P. and Shields-Zhou, G. (eds) (2011) The Geological Record of Neoproterozoic glaciations. Geol. Soc. London Mem., 36.

Bagshaw, E.A., Tranter, M., Fountain, A.G., Welch, K., Basagic, H.J. and Lyons, W.B. (2013) Do cryoconite holes have the potential to be significant sources of $\mathrm{C}, \mathrm{N}$, and $\mathrm{P}$ to downstream depauperate ecosystems of Taylor Valley, Antarctica? Arctic Alpine Antarctic Res., 45, 440-454.

Bao, H. (2015) Sulfate: A time capsule for Earth's $\mathrm{O}_{2}, \mathrm{O}_{3}$ and $\mathrm{H}_{2} \mathrm{O}$. Chem. Geol., 396, 108-118.

Bao, H., Lyons, J.R., and Zhou, C. (2008) Triple oxygen isotope evidence for elevated $\mathrm{CO}_{2}$ levels after a Neoproterozoic glaciation. Nature, 453, 504-506.

Bao, H., Fairchild, I.J., Wynn, P.M. and Spötl, C. (2009) Stretching the envelope of past surface environments: Neoproterozoic glacial lakes from Svalbard. Science, 323, 119-122.

Bao, H., Chen, Z.Q. and Zhou, C.M. (2012) An O-17 record of late Neoproterozoic glaciation in the Kimberley region, Western Australia. Precamb. Res., 216-219, 152-161.

Barrett, P. J. (2007) Cenozoic climate and sea level history from glacimarine strata off the Victoria Land coast, Cape Roberts Project, Antarctica. In: Glacial Processes and Products, eds. M. J. Hambrey, P. Christoffersen, N. F. Glasser, and B. Hubbart. Int. Ass. Sedimentologists Spec. Publ. 39,259-287.

This article is protected by copyright. All rights reserved. 
Barrett, P.J. (2013) Resolving views on Antarctic Neogene glacial history - the Sirius debate. Earth Env. Sci Trans.Roy. Soc. Edin., 104, 31-53.

Barrett, P. J. and Hambrey, M. J. (1992) Plio-Pleistocene sedimentation in Ferrar Fjord, Antarctica. Sedimentology, 39, 109-123.

Benn, D.I, Le Hir, G., Bao, H., Donnadieu, Y., Dumas, C., Fleming E.J., Hambrey, M.J., McMillan, E.A., Petronis, M.J., Ramstein, G., Stevenson, C.T.E., Wynn, P.M. and Fairchild, I.J. (2015) Orbitally forced ice sheet fluctuations during the Marinoan Snowball Earth glaciation Nature Geoscience, 8, 704-707.

Berner, R.A. (2004) The Phanerozoic Carbon Cycle. OUP.

Bischoff, J L., Fitzpatrick, J.A. and Rosenbauer, R.J. (1993) The solubility and stabilization of ikaite $\left(\mathrm{CaCO}_{3} 6 \mathrm{H}_{2} \mathrm{O}\right)$ from $0^{\circ}$ to $25^{\circ} \mathrm{C}$ : Environmental and palaeoclimatic implications for thinolitic tufa. J. Geol., 101, 21-33.

Bosak, T. and Newman, D.K. (2003) Microbial nucleation of calcium carbonate in the Precambrian. Geology, 31, 577-580.

Brasier, A.T. (2011) Searching for travertines, calcretes and speleothems in deep time: Processes, appearances, predictions and the impact of plants. Earth-Sci. Rev., 104, 213-239.

Buchardt, B., Israelson, C., Seaman, P. and Stockmann, G. (2001) Ikaite tufa towers in Ikka Fjord, southwest Greenland: their formation by mixing of seawater and alkaline spring water. J. Sedim. Res., 71, 176-189.

Budyko, M.I. (1969) The effects of solar radiation variations on the climate of the Earth. Tellus, XXI, 611-619.

Burton, E.A. (1993) Controls on marine carbonate mineralogy: review and assessment. Chem. Geol., 105, 163-179.

Caldeira, K. and Kasting, J.F. (1992) Susceptibility of the early Earth to irreversible glaciation caused by carbon dioxide clouds. Science, 359, 226-228.

Calkin, P.E. and Rutford, R.H. (1974) The Sand Dunes of Victoria Valley, Antarctica. Geog. Rev., 64,189-216.

Callow, R.H.T., Battison, L. and Brasier, M.D. (2011) Diverse microbially induced sedimentary structures from $1 \mathrm{Ga}$ lakes of the Diabaig Formation, Torridon Group, northwest Scotland. Sediment. Geol., 239, 117-128.

Calver, C. R., Crowley, J.L., Wingate, M.T.D., Evans, D.A.D., Raub, T.D. and Schmitz, M.D. (2013) Globally synchronous Marinoan deglaciation indicated by U-Pb geochronology of the Cottons Breccia, Tasmania, Australia. Geology, 41, 1127-1130.

Cao, X. and Bao, H. (2013) Dynamic model constraints on oxygen-17 depletion in atmospheric $\mathrm{O}_{2}$ after a snowball Earth. Proc. Natl. Acad Sci. USA, 110, 14546-14550.

Cawood, P.A., Nemchin, A., Strachan, R., Prave, T. and Krebbendam, M. (2007) Sedimentary basin and detrital zircon records along East Laurentia and Baltica during assembly and breakup of Rodinia. J. Geol. Soc. Lond., 164, 257-275.

Cohen, A.S. and Thouin, C. (1987) Nearshore carbonate deposits in Lake Tanganyika. Geology, 15, 414-418.

Creveling, J.R. and Mitrovica, J.X. (2014) The sea-level fingerprint of a Snowball Earth deglaciation. Earth Planet. Sci. Lett., 399, 74-85.

Dahl, K. and Buchardt, B. (2006) Monohydrocalcite in the Arctic Ikka Fjord, SW Greenland: First reported marine occurrence. J. Sedim. Res., 76, 460-471.

This article is protected by copyright. All rights reserved. 
Dana, E.S. (1884) A crystallographic study of the thinolite of Lake Lahontan. U.S. Geol. Surv. Bull., 12, 429-450.

David, T.W.E., Taylor, J.G., Woolnough, W.G. and Foxall, H.G. (1905) Occurrence of the pseudomorph glendonite in New South Wales. Rec. Geol. Surv. N.S.W., 3, 161-179.

Davies, N.S. and Gibling, M.R. (2010) Paleozoic vegetation and the Siluro-Devonian rise of fluvial lateral accretion sets. Geology, 38, 51-54.

Dickson, J.L., Head, J.W., Levy, J.S. and Marchant, D.R. (2013) Don Juan Pond, Antarctica: Nearsurface $\mathrm{CaCl}_{2}$-brine feeding Earth's most saline lake and implications for Mars. Sci. Rep., 3, 1166. DOI: 10.1038/srep01166.

Domack, E.W. and Hoffman, P. (2013) An ice grounding-line wedge from the Ghaub glaciations (635 $\mathrm{Ma}$ ) on the distal foreslope of the Otavi carbonate platform, Namibia, and its bearing on the snowball Earth hypothesis. Geol. Soc. Am. Bull., 123, 1448-1477.

Doran, P.T., McKay, C.P., Fountain, A.G., Nylen, T., McKnight, D.M., Jaros, C. and Barrett, J.E. (2008) Hydrologic response to extreme warm and cold summers in the McMurdo Dry Valleys, East Antarctica. Antarct. Sci., 20, 499-509.

Dowdeswell, J.A., Hambrey, M.J. and Wu, R.T. (1985) Clast shape and fabric in Precambrian and modern glacial sediments. J. Sedim. Petrol. 55, 691-704.

Dutkiewicz, A., Herczeg, A.L. and Dighton, J.C. (2000) Past changes to isotopic and solute balances in a continental playa: clues from stable isotopes of lacustrine carbonates. Chem. Geol., 165, 309329.

Elsig, J., Schmitt, J., Leuenberger, D., Schneider, R., Eyer, M., Leuenberger, M., Joos, F., Fischer, H. and Stocker, T.F. (2009) Stable isotope constraints on Holocene carbon cycle changes from an Antarctic ice core. Nature, 461, 507-510.

Etienne, J.L., Allen, P.A., Rieu, R. and Le Guerroué, E. (2007) Neoproterozoic glaciated basins: a critical review of the Snowball Earth hypothesis by comparison with Phanerozoic glaciations. In: Hambrey, M.J., Christoffersen, P., Glasser, N.F. \& Hubbard, B. (eds.) Glacial Processes and Products. Special Publication of the International Association of Sedimentologists, doi: 10.1002/9781444304435.ch19.

Ewing, R.C., Eisenman, I., Lamb, M.P., Poppick, L., Maloof, A.C. and Fischer, W.W. (2014) New constraints on equatiorial temperatures during a Late Neoproterozoic snowball Earth glaciation. Earth Planet. Sci. Lett., 406, 110-122.

Fairchild, I.J. (1980) Sedimentation and origin of a late Precambrian 'dolomite' from Scotland. J. Sedim. Petrol., 40, 423-446.

Fairchild, I.J. (1983) Effects of glacial transport and neomorphism on Precambrian dolomite crystal sizes. Nature, 304, 714-716.

Fairchild, I. J. (1991) Origins of carbonate in Neoproterozoic stromatolites and the identification of modern analogues. Precamb. Res., 53, 281-299.

Fairchild, I.J. (1993) Balmy shores and icy wastes: the paradox of carbonates associated with glacial deposits in Neoproterozoic times. In Wright, V.P. (ed.) Sedimentology Rev., 1, 1-16.

Fairchild, I.J. and Hambrey, M.J. 1984. The Vendian succession of northeastern Spitsbergen petrogenesis of a dolomite-tillite association. Precamb. Res., 26, 111-167.

Fairchild, I.J. and Spiro, B. (1987) Petrological and isotopic implications of some contrasting Precambrian carbonates, NE Spitsbergen. Sedimentology, 34, 973-989.

Fairchild, I.J. and Herrington, P.M. (1989) A tempestite-evaporite-stromatolite association (late Vendian, East Greenland): a shoreface-lagoon model. Precamb. Res., 43, 101-127

This article is protected by copyright. All rights reserved. 
Fairchild, I.J. and Hambrey, M.J. (1995) Vendian basin evolution in East Greenland and NE Svalbard. Precamb. Res., 73, 217-233.

Fairchild, I.J. and Kennedy, M.J. (2007) Neoproterozoic glaciation in the Earth System. J. Geol. Soc, London, 164, 895-921.

Fairchild, I.J. and Baker, A. (2012) Speleothem Science -from Process to Past Environment. Wiley, Chichester.

Fairchild, I.J., Hambrey, M.J., Spiro, B. \& Jefferson, T.H. (1989) Late Proterozoic glacial carbonates in northeast Spitsbergen: new insights into the carbonate-tillite association. Geol. Mag., 126, 469490.

Fairchild, I.J., Marshall, J.D. \& Bertrand-Sarfati, J. (1990) Stratigraphic shifts in carbon isotopes from Proterozoic stromatolitic carbonates (Mauritania) - influences of primary mineralogy and diagenesis. Am. J. Sci., 290A, 46-79.

Fairchild, I.J., Bradby, L., Sharp, M. and Tison, J.-L. (1994) Hydrochemistry of carbonate terrains in Alpine glacial settings. Earth Surf. Proc. Land., 19, 33-54.

Fairchild, I.J., Killawee, J.A. Hubbard, B. and Dreybrodt, W. (1999) Interactions of calcareous suspended sediment with glacial meltwater: a field test of dissolution behaviour. Chem. Geol., 155, 243-263.

Fairchild, I.J., Baker, A., Borsato, A., Frisia, S., Hinton, R.W., McDermott, F. and Tooth, A.F. (2001) High-resolution, multiple-trace-element variation in speleothems. J. Geol. Soc., London, 158, 831841.

Fairchild, I.J., Bonnand, P., Davies, T., Fleming, E.J., Grassineau, N., Halverson, G.P., Hambrey, M.J., McMillan, E.A., McKay, E., Parkinson, I.J. and Stevenson, C.T.E. (2016) The Late Cryogenian Warm Interval, NE Svalbard: chemostratigraphy and genesis of dolomitic shales. Precamb. Res. (submitted August 2015)

Fleming, E.J. (2014) Magnetic, structural and sedimentological analysis of glacial sediments: insights from modern, Quaternary and Neoproterozoic environments. University of Birmingham, unpubl. PhD. thesis, http://etheses.bham.ac.uk/5136/

Fleming, E.J., Stevenson, C.T.E., Petronis, M.S., Benn, D.I., Hambrey, M.J. and Fairchild, I.J. (2016) Criteria for the recognition of subglacial processes during a Neoproterozoic panglaciation, NE Svalbard" In revision for this issue, Sedimentology, xx, xxx-xxx.

Fountain, A.G., Lyons, W.B., Burkins, M.B., Dana, G.L., Doran, P.T., Lewis K.J., McKnight, D.M., Moorhead, D.L., Parsons, A.N., Priscu, J.C., Wall, D.H., Wharton, R.A. and Virginia, R.A. (1999) Physical controls on the Taylor valley ecosystem. Bioscience, 49, 961-971.

Frank, T.D., Thomas, S.G. and Fielding, C.R. (2008) On using carbon and oxygen isotope data from glendonites as paleoenvironmental proxies: A case study from the Permian System of eastern Australia. J. Sedim Res, 78, 713-723.

Gooseff, M.N., Lyons, W.B., McKnight, D.M., Vaughn, B.H., Fountain, A.G. and Dowling, C. (2006) A stable isotopic investigation of a polar desert hydrologic system, McMurdo Dry Valleys, Antarctica. Arctic, Antarctic, Alpine Res., 38, 60-71.

Green, W.J. and Lyons, W.B. (2009) The saline lakes of the McMurdo Dry Valleys, Antarctica. Aquat. Geochem., 15, 321-348.

Green W.J., Angle, M.P. and Chave, K.E. (1988) The geochemistry of Antarctic streams and their role in the evolution of four lakes of the McMurdo Dry valleys. Geochim. Cosmochim. Acta, 52, 12651274.

This article is protected by copyright. All rights reserved. 
Gregg, J.M., Howard, S.A. and Mazzullo, S.J. (1992) Early diagenetic recrystallization of Holocene (<3000 years old) peritidal dolomites, Ambergris Cay, Belize. Sedimentology, 39, 143-160.

Grotzinger, J.P. and Knoll, A.H. (1999) Stromatolites in Precambrian carbonates: Evolutionary mileposts or environmental dipsticks? Ann. Rev. Earth Planet. Sci., 27, 313-358.

Hall, B.L., Hendy, C.H. and Denton, G.H. (2006) Lake-ice conveyor deposits: Geomorphology, sedimentology, and importance in reconstructing the glacial history of the Dry Valleys. Geomorphology, 75, 143-156.

Hall, B.L., Denton, G.H., Sonte, J.O. and Conway, H. (2013) History of grounded ice sheet in the Ross Sea sector of Antarctica during the Last Glacial Maximum and the last termination. In: Hambrey, M.J., Barker, P.F., Barrett, P.J., Howman, V., Davies, B., Smellie, J.L. and Tranter, M. (eds.) Antarctic Palaeoenvironments and Earth-Surface Processes. Geol. Soc. London Spec. Publ., 381, 167-181.

Halley, R.B. (1977) Ooid fabric and fracture in the Great Salt Lake and the geologic record. J. Sedim. Petrol., 47, 1099-1120.

Halverson, G.P. (2006) A Neoproterozoic Chronology IN: Xiao, S. \& Kaufman, A.J. (Eds.) Neoproterozoic Geobiology and Paleobiology, Springer, New York, 231-271.

Halverson, G.P. (2011) Glacial sediments and associated strata of the Polarisbreen Group, northeastern Svalbard. In: Arnaud, E., Halverson, G. P. and Shields-Zhou, G. (eds) (2011) The Geological Record of Neoproterozoic glaciations. Geol. Soc. London Mem., 36, 571-579.

Halverson, G.P., Hoffman, P.F., Schrag, D.P. and Kaufman, A.J. (2002) A major perturbation of the carbon cycle before the Ghuab glaciation (Neoproterozoic) in Namibia: Prelude to snowball Earth? Geochem. Geophys. Geosyst., 3, 1035. doi: 10.1029/2001GC000244.

Halverson, G.P., Maloof, A.C. and Hoffman, P.F. (2004) The Marinoan glaciation (Neoproterozoic) in northeast Svalbard. Basin Res., 16, 297-324.

Halverson, G.P., Hoffman, P.F., Schrag, D.P., Maloof, A.C. and Rice, A.H.N. (2005) Towards a Neoproterozoic composite carbon-isotope record. Geol. Soc. Am. Bull., 117, 1181-1207.

Halverson, G.P., Wade, B.P., Hurtgen, M.T. and Barovich, K.M. (2010) Neoproterozoic chemostratigraphy. Precamb. Res., 182, 337-350

Hambrey, M.J. (1982) Late Precambrian diamictites of northeastern Svalbard. Geol. Mag., 119, 527551.

Hambrey, M. J. (1983) Correlation of Late Proterozoic tillites in the North Atlantic region and Europe. Geol. Mag., 120, 209-232.

Hambrey, M.J. and Spencer, A.M. (1987) Late Precambrian glaciation of central East Greenland. Medd. Grønland Geosci. 19.

Hambrey, M. J. and Barrett, P. J. (1993) Cenozoic sedimentary and climatic record, Ross Sea region, Antarctica. In: The Antarctic Paleoenvironment: a Perspective on Global Change, Part 2, ed. Kennett, J. P. and Warnke, D. A., Antarctic Research Series, Am. Geophys. Union, 91-124.

Hambrey, M.J. and Fitzsimons, S.J. (2010) Development of sediment-landform associations at cold glacier margins, Dry Valleys, Antarctica. Sedimentology, 57, 857-882.

Hambrey, M.J. and Glasser, N. (2012) Discriminating glacier thermal and dynamic regimes in the sedimentary record. Sedim. Geol., 251, 1-33.

Hambrey, M. J., Barrett, P. J. and Powell, R. D. (2002) Late Oligocene and early Miocene glacimarine sedimentation in the SW Ross Sea, Antarctica: the record from offshore drilling. In O'Cofaigh, C.

This article is protected by copyright. All rights reserved. 
and Dowdeswell, J. A. (eds.), Glacier-influence sedimentation on high-latitude continental margins. Spec. Publ. Geol. Soc. Lond., 203, 105-128.

Harland, W.B. (1964) Critical evidence for a great Infra-Cambrian glaciation. Geol. Rundsch., 54, 4561.

Harland, W.B. (1997) The Geology of Svalbard. Geol. Soc. London Mem., 17.

Harland, W. B., Hambrey, M. J. and Waddams, P. (1993) Vendian Geology of Svalbard. Norsk. Polarinst. Skr. 193, $150 \mathrm{pp}$.

Hendy, C.H. (1979) Late Pleistocene glacial chronology of the Taylor Valley, Antarctica, and the global climate. Quat. Res., 11, 72-84.

Hendy, C.H. (1980) Late Quaternary lakes in the McMurdo Sound region of Antarctica. Geografiska Annal., 82A, 411-432.

Hendy, C.H. Sadler, A.J., Denton, G.H. and Hall, B.L. (2000) Proglacial lake-ice conveyors: a new mechanism for the deposition of drift in polar environments. Geogr. Annal., 82A, 249-274.

Hoffman, P.F. (2011) Strange bedfellows: glacial diamictite and cap carbonate from the Marinoan (635 Ma) glaciations in Namibia. Sedimentology, 58, 57-119.

Hoffman, P.F. and Schrag, D.P. (2002) The snowball Earth hypothesis: testing the limits of global change. Terra Nova, 14, 129-155.

Hoffman, P.F., Kaufman, A.J., Halverson, G.P. and Schrag, D.P. (1998) A Neoproterozoic Snowball Earth. Science, 281, 1342-1346.

Hoffman, P.F., Halverson, G.P., Domack, E.W., Husson, J.M., Higgins, J.A. and Schrag, D.P. (2007) Are basal Ediacaran (635 Ma) post-glacial "cap dolostones" diachronous? Earth Planet. Sci. Lett., 258, 114-131.

Hoffman, P.F., Halverson, G.P., Domack, E.W., Maloof, A.C., Swanson-Hysell, N.L. and Cox, G.M. (2012) Cryogenian glaciations on the southern tropical paleomargin of Laurentia (NE Svalbard and East Greenland), and a primary origin for the upper Russøya (Islay) carbon isotope excursion. Precamb. Res., 206-207, 137-158.

Hood, A.V.S. and Wallace, M.W. (2012) Synsedimentary diagenesis in a Cryogenian reef complex: Ubiquitous marine dolomite precipitation. Sedim. Geol., 255-256, 56-71.

Hood, A.V.S. and Wallace, M.W. (2014) Marine cements reveal the structure of an anoxic, ferruginous Neoproterozoic ocean. J. Geol. Soc. London, 171, 741-744.

Huggett, J.M., Schultz, B.P., Shearman, D.J. and Smith, A.J. (2005) The petrology of ikaite pseudomorphs and their diagenesis. Proc. Geol. Assoc., 116, 207-220.

Hyde, W.T., Crowley, T.J., Baum, S.K. and Peltier, W.R. (2000) Neoproterozoic 'snowball Earth' simulations with a coupled climate/ice-sheet model. Nature, 405, 425-429.

Javoy, M., Pineau, F. and Delorme, H. (1986) Carbon and nitrogen isotopes in the mantle. Chem. Geol., 57, 41-62.

Kaczmarek, S.E. and Sibley, D.F. (2014) Direct physical evidence of dolomite recrystallization. Sedimentology, 61, 1862-1882.

Kalugin, I., Darin, A., Rogozin, D. and Tretyakov, G. (2013) Seasonal and centennial cycles of carbonate mineralisation during the past 2500 years from varved sediment in Lake Shira, South Siberia. Quat. Int., 290-291, 245-252.

Kaufman, A.J., Knoll, A.H. and Narbonne, G.M. (1997) Isotopes, ice ages, and terminal Proterozoic earth history. Proc. Natl. Acad, Sci. USA, 94, 6600-6605.

This article is protected by copyright. All rights reserved. 
Kawano, J., Shimobayashi, N., Miyake, A. and Kitamura, M. (2009) Precipitation diagram of calcium carbonate polymorphs: its construction and significance. J. Phys. Condens. Matter, 21, doi:10.1088/0953-8984/21/42/425102.

Kelts, K. and Hsü, K.J. (1978) Freshwater carbonate sedimentation. In: Lerman, A. (Ed.), Lakes. Chemistry, Geology, Physics. Springer Verlag, New York, pp. 295-323.

Kennedy, M.J., Christie-Blick, N. and Sohl, L.E. (2001a) Are Proterozoic cap carbonates and isotopic excursions a record of gas hydrate destabilization following Earth's coldest intervals? Geology, 29, 443-446.

Kennedy, M.J., Christie-Blick, N. and Prave, A.R. (2001b) Carbon isotopic composition of Neoproterozoic glacial carbonates as a test of paleoceanographic models for snowball Earth phenomena. Geology, 29, 1135-1138.

Kennedy, M., Droser, M., Mayer, L.M., Pevear, D. and Mrofka, D. (2006) Late Precambrian oxygenation: Inception of the clay mineral factory. Science, 311, 1446-1449.

Kennedy, M.J., Mrofka, D. and von der Borch, C.C. (2008) Snowball earth termination by destabilization of equatorial permafrost methane clathrate. Nature, 453, 642-645.

Kennedy, M.J. and Christie-Blick, N. (2011) Condensation origin for Neoproterozoic cap carbonates during deglaciation. Geology, 39, 319-322.

Killingsworth, B.A., Hayles, J.A., Zhou, C. and Bao, H. (2013) Sedimentary constraints on the duration of the Marinoan Oxygen-17 depletion (MOSD) event. Proc. Natl. Acad. Sci., 110, 1768617690.

Kim, S.T. and O'Neil, J.R. (1997) Equilibrium and nonequilibrium oxygen isotope effects in synthetic carbonates. Geochim. Comochim. Acta, 61, 3461-3475.

Kirschvink, J.L. (1992) Late Proterozoic Low-Latitude Global Glaciation: the Snowball Earth. In: Schopf, J.W., Klein, C. (Eds.), The Proterozoic Biosphere: A Multidisciplinary Study. Cambridge University Press, pp. 51-52.

Klappa, C.F. (1979) Lichen stromatolites: Criteria for subaerial exposure and a mechanism for the formation of laminar calcretes (caliche). J. Sedim. Petrol., 49, 387-400.

Knoll, A.H. and Swett, K. (1990) Carbonate deposition during the Late Proterozoic Era: an example from Spitsbergen. Am. J. Sci., 290-A, 104-132.

Knoll, A.H., Hayes, J.M., Kaufman, A.J., Swett, K. and Lambert, I.B. (1986) Secular variation in carbon isotope ratios from Upper Proterozoic successions of Svalbard and East Greenland. Nature, 321, 832-838.

Knoll, A.H., Fairchild, I.J. and Swett, K. (1993) Calcified microbes in Neoproterozoic carbonates implications for our understanding of the Proterozoic Cambrian transition. Palaios, 8, 512-525.

Kulling, O. (1934) Scientific Results of the Swedish--Norwegian Arctic Expedition in the summer of 1931. XI. 'The Hecla Hoek Formation' around Hinlopenstretet. Geogr. Annlr. Stockh., 16, 161-254.

Lan, Z, Liu, X., Zhu, M., Chen, Z., Zhang, Q., Li, Q., Lu, D., Liu, Y. and Tang G. (2014) A rapid and synchronous initiation of the widespread Cryogenianglaciations. Precamb. Res., http://dx.doi.org/10.1016/j.precamres.2014.10.015

Lancaster, N. and Teller, J.L. (1988) Interdune deposits of the Namib Sand Sea. Sediment. Geol. 55, 91-107.

Land, L.S. (1980) The isotopic and trace element geochemistry of dolomite: the state of the art. In (D.H. Zenger, J.B. Dunham \& R.L. Ethington eds.), Concepts and Models of Dolomitization, SEPM Spec. Publ., 28, 87-110.

This article is protected by copyright. All rights reserved. 
Larsen, D. (1994) Origin and paleoenvironmental significance of calcite pseudomorphs after ikaite in the Oligocene Creede Formation, Colorado. J. Sed. Res., A64, 593-603.

Last, F.M., Last, W.M., Fayek, M., Halden, N.M. (2013) Occurrence and significance of a cold-water carbonate pseudomorph in microbialites from a saline lake. J. Paleolimnol., 50, 505-517.

Lauterbach, S., Baruer, A., Andersen, N., Danielpol, D.L., Dulski, P., Hüls, M., Milecka, K., Namiotko, T., Obremska, M., von Grafenstein, U. and Declakes Participants. (2011) Environmental responses to Lateglacial climatic fluctuations recorded in the sediments of preAlpine Lake Mondsee (northeastern Alps). J. Quat. Sci., 26, 253-267.

Lawrence, M.J.F. and Hendy, C.H. (1985) Water column and sediment characteristics of Lake Fryxell, Taylor Valley, Antarctica. NZ J. Geol. Geophys., 28, 543-552.

Le Heron, D.P., Cox, G., Trundley, A. and Collins, A. (2011) Sea ice-free conditions during the Sturtian glaciations (early Cryogenian), South Australia. Geology, 39, 31-34.

Le Heron, D.P., Busfield, M. And Kamona, F. (2013) An interglacial on Snowball Earth? Dynamic ice behaviour revealed in the Chuos Formation, Namibia. Sedimentology, 60, 411-427.

Le Hir, G., Ramstein, G., Donnadieu, Y. and Goddéris, Y. (2008) Scenario for the evolution of atmospheric $\mathrm{pCO}_{2}$ during a snowball Earth. Geology, 36, 47-50.

Le Hir, G., Donnadieu, Y., Goddéris, Y., Pierrehumbert, R.T., Halverson, G.P., Macouin, M., Nédélec, A. and Ramstein, G. (2009) The Snowball Earth aftermath: Exploring the limits of continental weathering processes. Eath Planet. Sci. Lett., 277, 453-463.

Leng, M.J. and Marshall, J.D. (2004) Palaeoclimate interpretation of stable isotope data from lake sediment archives. Quat. Sci. Rev., 23, 811-831.

Lewis, A.R., Marchant, D.R., Ashworth, A.C., Hemming, S.R. and Machlus, M.L. (2007) Major middle Miocene global climate change: Evidence from East Antarctica and the Transantarctic Mountains. Geol. Soc. Am. Bull., 119, 1449-1461.

Li, Z.-X., Evans, D.A.D. and Halverson, G.P. (2013) Neoproterozoic glaciations in a revised global palaeogeography from the breakup of Rodinia to the assembly of Gondwanaland. Sed. Geol., 294, 219-232.

Lloyd, R.M. (1966) Oxygen isotope enrichment of sea water by evaporation. Geochim. Cosmochim. Acta, 30, 801-814.

Lyons, W.B., Priscu, J.C., Laybourn-Parry, J., Moorhead, D., McKnight, D.M., Doran, P.T. and Tranter, M. (2001) The McMurdo Dry Valleys long-term ecological research program: new understanding of the biogeochemistry of the Dry Valley lakes: a review. Polar Geog., 25, 202-217.

Lyons, W.B., Leslie, D.L., Harmon, R.S., Neumann, K., Welch, K.A., Bisson, K.M. and McKnight, D.M. (2013) The carbon stable isotope biogeochemistry of streams, Taylor Valley, Antarctica. Appl. Geochem., 32, 26-36.

Macdonald, F.A., Schmitz, M.D., Crowley, J.L., Roots, C.F., Jones, D.S., Maloof, A.C., Strauss, J.V., Cohen, P.A., Johnston, D.T. and Schrag, D.P. (2010) Calibrating the Cryogenian. Science, 327, 1241-1243.

Marchant, D.R. and Head, J.W. (2007) Antarctic dry valleys: Microclimate zonation, variable geomorphic processes, and implications for assessing climate change on Mars. Icarus, 192, 187222.

Marchant, D.R., Mackay, S.L., Lamp, J.L., Hayden, A.T. and Head, J.W. (2013) A review of geomorphic processes and landforms in the Dry Valleys of southern Victoria Land: implications for evaluating climate change and ice-sheet stability. In: Hambrey, M.J., Barker, P.F., Barrett, P.J.,

This article is protected by copyright. All rights reserved. 
Howman, V., Davies, B., Smellie, J.L. and Tranter, M. (eds.) Antarctic Palaeoenvironments and Earth-Surface Pro.cesses. Geol. Soc. London Spec. Publ., 381, 319-352.

Matsubaya, O., Sakai, H., Torii, T., Burton, H. and Kerry, K. (1979) Antarctic saline lakes -stable isotope ratios, chemical compositions and evolution. Geochim. Cosmochim. Acta, 43, 7-25.

McKelvey, B.C. (1979) The Miocene-Pleistocene stratigraphy of eastern Taylor Valley - an interpretation of DVDP Cores 10 and 11. Tokyo. National institute of Polar Research - Mem. Spec. Iss. 13, 176-186.

McKnight, D.M., Niyogi, D.K., Alger, A.S., Bomblies, A., Conovitz, P.A. and Tate, C.M. (1999) Dry Valley streams in Antarctica: Ecosystems waiting for water. Bioscience, 49, 985-995.

McKnight, D.M., Tate, C.M., Andrews, E.D., Niyogi, D.K., Cozzetto, K., Welch, K., Lyons, W.B. and Capoine, D.G. (2007) Reactivation of a cryptobiontic stream ecosystem in the McMurdo Dry Valleys, Antarctica: A long-term geomorphological experiment. Geomorphology, 89, 186-204.

Mikucki, J.A. and Priscu, J.C. (2007) Bacterial diversity associated with Blood Falls, a subglacial outflow from the Taylor Glaicer. Appl. Env. Microbiol., 12, 4029-4039.

Moncrieff, A.C.M. and Hambrey, M.J. (1990) Marginal-marine glacial sedimentation in the late Precambrian succession of east Greenland. In: Dowdeswell, J.A. and Scourse, J.D. (eds.) Glacimarine Environments: Processes and Sediments. Geol. Soc. London Spec. Publ., 53, 387-410.

Mook, W., Bommerson, J. and Staverman, W. (1974) Carbon isotope fractionation between dissolved bicarbonate and gaseous carbon dioxide. Earth Planet. Sci. Lett., 22, 169-176.

Mountney, N.P. and Thompson, D.B. (2002) Stratigraphic evolution and preservation of Aeolian dune and damp/wet interdune strata: an example from the Triassic Helsby Sandstone Formation, Cheshire Basin, UK. Sedimentology, 49, 805-833.

Müller, G., Irion, G. and Förstner, U. (1972) Formation and diagenesis of inorganic Ca-Mg carbonates in the lacustrine environment. Naturwissenschaften, 59, 158-164.

Naish, T.R., Powell, R.D., Barrett, P.J., Levy, R.H., Henry, S., Wilson, G.S., Krissek, L.A., Niessen, F., Pompilio, M., Ross, J., Scherer, R., Talarico, F., Pyne, A. and the ANDRILL-MIS Science team (2008) Late Cenozoic Climate History of the Ross Embayment from the AND-1B Drill Hole: Culmination of Three Decades of Antarctic Margin Drilling. In: Cooper, A. K., P. J. Barrett, H. Stagg, B. Storey, E. Stump, W. Wise, and the 10th ISAES editorial team, eds. Antarctica: A Keystone in a Changing World. Proceedings of the 10th International Symposium on Antarctic Earth Sciences. Washington, DC: The National Academies Press. doi:10.3133/of2007-1047.kp07

Nakai, N., Wada, H., Kiyosu, Y. and Takimoto, M. (1975) Stable isotope studies on the origin and geological history of water and salts in the Lake Vanda area, Antarctica. Geochem. J., 9, 7-24.

Neugebauer, I., Brauer, A., Dräger, N., Dulski, P., Wulf, S., Plessen, B., Mingram, J., Herzschuh, U. and Brande, A. (2012) A Younger Dryas varve chronology from the Rehweise palaeolake record in NE-Germany. Quat. Sci. Rev., 36, 91-102.

Neumann, K., Lyons, W.B., Priscu, J.C., Desmarais, D.J. and Welch, K.A. (2004) The carbon isotopic composition of dissolved inorganic carbon in perennially ice-covered Antarctic lakes: searching for a biogenic signature. Annals Glac., 39, 518-524.

Neuser, R.D. and Richter, D.K. (2007) Non-marine radiaxial fibrous calcites - examples of speleothems proved by electron backscatter diffraction. Sediment. Geol., 194, 149-154.

Nomura, D., Assmy, P., Nehrke, G., Granskog, M.A., Fischer, M., Dieckmann, G.S., Fransson, A., Hu, Y. and Schnetger, B. (2013) Characterization of ikaite $\left(\mathrm{CaCO}_{3} \cdot 6 \mathrm{H}_{2} \mathrm{O}\right)$ crystals in first-year Arctic sea ice north of Svalbard. Ann. Glaciol., 54, 125-131.

This article is protected by copyright. All rights reserved. 
Nylen, T.H., Fountain, A.G. and Doran, P.T. (2004) Climatology of katabatic winds in the McMurdo dry valleys, southern Victoria Land, Antarctica. J. Geophys. Res. Atm. 109, D03114. doi: 10.1029/2003JD003937.

Oehlerich, M., Mayr, C., Griesshaber, E., Lücke, A., Oeckler, O.M., Ohlendorf, C., Schmahl, W.W. and Zolitschka, B. (2013) Ikaite precipitation in a lacustrine environment - implications for palaeoclimatic studies using carbonates from Laguna Potrok Alke (Patagonia, Argentina). Quat. Sci. Rev., 71, 46-53.

Parker, B.C., Simmons, G.M., Love, F.G., Wharton, R.A. and Seaburg, K.G. (1981) Modern stromatolites in Antarctic Dry Valley lakes. Bioscience, 31, 656-661.

Peng, Y., Bao, H., Zhou, C., Yuan, X. and Luo, T. (2013) Oxygen isotope composition of meltwater from a Neoproterozoic glaciation in South China. Geology, 41, 367-370.

Pierrehumbert, R.T. (2005) Climate dynamics of a hard snowball Earth. J. Geophys. Res., 110, D01111, doi:1029/2004JD005162.

Pierrehumbert, R.T., Abbot, D.S., Voigt, A. and Koll, D. (2011) Climate of the Neoproterozoic. Ann. Rev. Earth Planet. Sci., 39, 417-460.

Planavsky, N.J., Rouxel, O.J., Bakker, A., Lalonde, S.V., Konhauser, K.O., Reinhard, C.T. and Lyons, T.W. (2010) The evolution of the marine phosphate reservoir. Nature, 467, 1088-1090.

Pollock, M.D., Kah, L.C. and Bartley, J.K. (2006) Morphology of molar-tooth structures in Precambrian carbonates: Influence of substrate rheology and implications for genesis. J. Sedim. Res., 76, 310-323.

Powers, D.W. and Easterling, R.G. (1982) Improved methodology for using embedded Markov chains to describe cyclical sediments. J. Sedim. Petrol., 52, 913-923.

Propenko, A.A. and Williams, D.F. (2005) Depleted methane-derived carbon in waters of Lake Baikal, Siberia. Hydrobiologia, 544, 279-288.

Radke, B.M. and Mathis, R.L. (1980) On the formation and occurrence of saddle dolomite. J. Sedim. Petrol., 50, 1149-1168.

Rao, C.P., Goodwin, I.D. and Gibson, J.A.E. (1998) Shelf, coastal and subglacial polar carbonates, East Antarctica. Carbonates and Evaporites, 13, 174-188.

Retallack, G.J., Gose, B.N. and Osterhour, J.T. (2015) Periglacial paleosols and Cryogenian palaeoclimate near Adelaide, South Australia. Precamb. Res., 263, 1-18.

Riccioni, R.-M., Brock, P.W.G. and Schreiber, B.C. (1996) Evidence for early aragonite in paleolacustrine sediments. J. Sedim Res., 66, 1003-1010.

Riding, R. (2000) Microbial carbonates: the geological record of calcified bacterial-algal mats and biofilms. Sedimentology, 47 (suppl. 1), 179-214.

Robinson, Z.P., Fairchild, I.J. and Arrowsmith, C. (2009) Stable isotope tracers of shallow groundwater recharge dynamics and mixing within an Icelandic sandur, Skeiðarársandur. Hydrology in Mountain Regions: Observations, Processes and Dynamics (Proceedings of Symposium HS1003 at IUGG2007, Perugia, July 2007). Int. Assoc. Hydrol. Sci. Publ. 326, 119-125.

Rodriguez-Blanco, J.D., Shaw, S., Bots, P., Roncal-Herrero, T. and Benning, L.G. (2014) The role of $\mathrm{Mg}$ in the crystallization of monohydrocalcite. Geochim. Cosmochim. Acta, 127, 204-220.

Rooney, A.D., Macdonald, F.A., Strauss, J.V., Dudás, F.O., Hallmann, C. and Selby, D. (2014) Re-Os geochronology and coupled Os-Sr isotope constraints on the Sturtian snowball Earth. Proc. Natl. Acad. Sci., 111, 51-56.

This article is protected by copyright. All rights reserved. 
Rooney, A.D., Strauss, J.V., Brandon, A.D. and Macdonald, F.A. (2015) A Cryogenian chronology: Two long-lasting synchronous Neoproterozoic glaciations. Geology, 43, 459-462.

Rose, B.E.J. (2015) Stable "Waterbelt" climates controlled by tropical heat transport: A non-linear coupled mechanisms of relevance to Snowball Earth. J. Geophys. Res. A, 120, 10.1002/2014JD022659

Schrag, D.P., Berner, R.A., Hoffman, P.F. and Halverson, G.P. (2002) On the initiation of a snowball Earth. Geochem. Geophys. Geosyst., 3, 1036. doi: 10.1029/2001GC000219.

Sekkal, W. and Zaoui, A. (2013) Nanoscale analysis of the morphology and surface stability of calcium carbonate polymorphs. Sci. Rep., 3, 1587. Doi: 10.1038/srep01587.

Selleck, B.W., Carr, P.F. and Jones, B.G. (2007) A review and synthesis of glendonites (pseudomorphs after ikaite) with new data: assessing applicability as recorders of ancient coldwater conditions. J. Sedim. Res., 77, 980-991.

Shanahan, T.M., Overpeck, J.T., Beck, J.W., Wheeler, C.W., Peck, J.A., King, J.W. and Scholz, C.A. (2008) The formation of biogeochemical laminations in Lake Bosumtwi, Ghana, and their usefulness as indicators of past environmental changes. J. Paleolimnol., 40, 339-355.

Shearman, D.J. and Smith, A.J. (1985) Ikaite, the parent mineral of jarrowite-type pseudomorphs. Proc. Geol. Assoc., 96, 305-314.

Shearman, D.J., McGugan, A., Stein, C. and Smith, A.J. (1989) Ikaite, $\mathrm{CaCO}_{3} \cdot \mathrm{H}_{2} \mathrm{O}$, precursor of the thinolites in the Quaternary tufas, and tufa mounds of the Lahontan and Mono Lake Basins, western United States. Geol. Soc. Am. Bull., 101, 913-917.

Simmons, G.M., Vestal, J.R. and Wharton, R.A. (1993) Environmental regulators of microbial activity in continental Antarctic lakes. In: W. J. Green and E. I. Friedmann (eds.), Physical and Biogeochemical Processes in Antarctic Lakes Am. Geophys. Union Antarct. Res. Ser., 59, 165-195.

Speirs, J.C., McGowan, H., Steinhoff, D.F. and Bromwich, D.H. (2013) Regional climate variability driven by foehn winds in the McMurdo Dry Valleys, Antarctica. Int. J. Climatol., 33, 945-958.

Spötl, C. and Wright, V.P. (1992) Groundwater dolocretes from the Upper Triassic of the Paris Basin, France: a case study of an arid, continental diagenetic facies. Sedimentology, 39, 1119-1136.

Stockhecke, M., Anselmetti, F.S., Meydan, A.F., Odermatt, D. and Sturm, M. (2012) The annual particle cycle in Lake Van (Turkey). Palaeogeog. Palaeoclimatol. Palaeocol., 333-334, 148-159.

Sugden, D.E., Marchant, D.R., Potter, N., Souchez, R.A., Donton, G.H., Swisher, C.C. and Tison, J.-L. (1995) Preservation of Miocene glacier ice in East Antarctica. Nature, 376, 412-414.

Swainson, I.P. and Hammond, R.P. (2001) Ikaite, $\mathrm{CaCO}_{3} \cdot 6 \mathrm{H}_{2} \mathrm{O}$ : Cold comfort for glendonites as paleothermometers. Am. Mineral., 86, 1530-1533.

Talbot, M.R. (1990) A review of the palaeohydrological interpretation of carbon and oxygen isotopic ratios in primary lacustrine carbonates. Che. Geol. (Isot. Geosci.), 80, 261-279.

Tandon, S.K. and Friend, P.F. (1989) Near-surface shrinkage and carbonate replacement processes, Arran Cornstone Formation, Scotland.Sedimentology, 36, 1113-1126.

Trindade, R.I.F., Font, E., D’Agrella, M.S., Nogueira, A.C.R. and Riccomini, C. (2003) Low-latitude and multiple geomagnetic reversals in the Neoproterozoic Puga cap carbonate, Amazon craton. Terra Nova, 15, 441-446.

Vasconcelos, C., McKenzie, J.A., Warthmann, R. and Bernasconi, S.M. (2005) Calibration of the $\delta^{18} O$ paleothermometer for dolomite precipitated in microbial cultures and natural environments.

Geology, 33, 317-320.

This article is protected by copyright. All rights reserved. 
Virtasolo, J.J., Leipe, T., Moros, M. and Kotilainen, A.T. (2011) Physicochemical and biological influences on sedimentary-fabric formation in a salinity and oxygen-restricted semi-enclosed sea: Gotland Deep, Baltic Sea. Sedimentology, 58, 352-375.

Voorhuis, A.A., Biddanda, B.A., Kendall, S.T., Jain, S., Marcus, D.N., Nold, S.D., Sheldon, N.D. and Dick, G.J. (2012) Cyanobacterial life at low $\mathrm{O}_{2}$ : community genomics and function reveal metabolic versatility and extremely low diversity in a Great Lakes sinkhole mat. Geobiology, 10, 250-267.

Walter, M.R. and Bauld, J. (1983) The association of sulphate evaporites, stromatolitic carbonates and glacial sediments. Examples from the Proterozoic of Australia and the Cainozoic of Antarctica. Precamb. Res. 21, 129-148.

Warren, J. (2000) Dolomite: occurrence, evolution and economically important association. EarthSci. Rev., 52, 1-81.

Wharton, R.A., Parker, B.C., Simmons, G.M., Seaburg, K.G. and Love, F.G. (1982) Biogenic calcite structures forming in Lake Fryxell, Antarctica. Nature, 293, 293-295.

Williams, G.E. (1979) Sedimentology, stable-isotope geochemistry and palaeoenvironment of dolostones capping late Precambrian glacial sequences in Australia. J. Geol. Soc. Aust., 26, 377386.

Williams, G.E. (2008) Proterozoic (pre-Ediacaran) glaciation and the high obliquity, low-latitude ice, strong seasonality (HOLIST) hypothesis: Principles and tests. Earth-Sci. Rev., 87, 61-93.

Wilson, A.T. (1981) A review of the geochemistry and lake physics of the Antarctic dry areas. In (ed. L.D. McGinnis). Dry Valley Drilling Project pp. 185-192. Washington: Am. Geophys. Union.

Wilson, C.B. and Harland, W.B. (1964) The Polarisbreen Series and other evidences of late PreCambrian ice ages. Geol. Mag., 101, 198-219.

Wright, V.P. (1990) A micromorphological classification of fossil and recent calcic and petrocalcic microstructures. In: Douglas, L.A. (Ed.) Soil Micromorphology: A Basic and Applied Science. Elsevier, Amsterdam, pp. 401- 407.

Wright, V.P. and Tucker, M.E. (2009) Calcretes: an introduction. In Wright, V.P. \& Tucker, M.E. (eds.) Calcretes. Int. Assoc. Sedimentol. Reprint Series, 1-24.

Xiao, S., Bao, H., Wang, H., Kaufman, A.J., Zhou, C., Li, G., Yuan, X. and Ling, H. (2004) The Neoproterozoic Quruqtagh Group in eastern Chinese Tianshan: evidence for a post-Marinoan glaciation. Precamb. Res. 130, 1-26.

Zhang, F., Xu, H., Konishi, H., Kemp, J.M., Roden, E.E. and Shen, Z. (2012) Dissolved sulphidecatalyzed precipitation of disordered dolomite: Implications for the formation mechanism of sedimentary dolomite. Geochim. Cosmochim. Acta, 97, 148-165.

Zhao, Y.Y. and Zheng, Y.F. (2010) Stable isotope evidence for involvement of deglacial meltwater in Ediacaran carbonates in South China. Chem. Geol., 271, 86-100.

Zhou, X., Lu, Z., Rickaby, R.E.M., Domack, E.W., Wellner, J.S., and Kennedy, H.A. (2015) Ikaite Abundance controlled by porewater phosphorus level: Potential links to dust and productivity. $J$. Geol., 123, 269-281.

This article is protected by copyright. All rights reserved. 
Table 1: Neoproterozoic chronostratigraphy and north-east Svalbard lithostratigraphy (after Halverson, 2011, updated by unpublished data). Glacial units highlighted in red. This paper deals with the Wilsonbreen Formation, representing the younger of the two Cryogenian glaciations.

\begin{tabular}{|c|c|c|c|c|c|c|}
\hline $\begin{array}{l}\text { Geologi } \\
\text { cal } \\
\text { System }\end{array}$ & $\begin{array}{c}\text { Grou } \\
\text { p }\end{array}$ & $\begin{array}{c}\text { Format } \\
\text { ion }\end{array}$ & Member & $\begin{array}{c}\text { Thic } \\
\text { k- } \\
\text { nes } \\
\text { s } \\
\text { (m) }\end{array}$ & Lithologies & Interpreted environment \\
\hline \multirow{2}{*}{$\begin{array}{l}\text { Ediaca } \\
\text { ran }\end{array}$} & \multirow{8}{*}{ 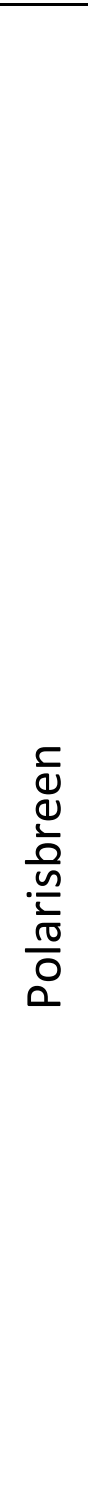 } & \multirow{2}{*}{$\begin{array}{c}\text { Dracois } \\
\text { en }\end{array}$} & D4 to D7 & 265 & $\begin{array}{c}\text { Sandstones and mudstones } \\
\text { (D4 and D6); dolomite D5 and } \\
\text { D7 }\end{array}$ & Playas (D4 to D6); Coastal (D7) \\
\hline & & & D1 to $\mathrm{D} 3$ & 200 & $\begin{array}{l}\text { Cap carbonate (D1) transitional } \\
\text { (D2) to black shale D3) }\end{array}$ & $\begin{array}{c}\text { Transgressive coastal (D1) to } \\
\text { offshore (D2-D3) }\end{array}$ \\
\hline \multirow{6}{*}{$\begin{array}{l}\frac{c}{\sigma} \\
\frac{\pi}{c} \\
0 \\
0\end{array}$} & & \multirow{3}{*}{ 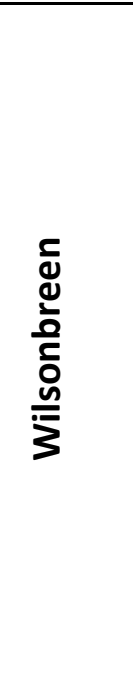 } & $\begin{array}{c}\text { W3 } \\
\text { (Gropbreen) }\end{array}$ & $\begin{array}{l}65- \\
95\end{array}$ & $\begin{array}{l}\text { Diamictites and sandstones } \\
\text { with minor limestone }\end{array}$ & $\begin{array}{c}\text { Glacilacustrine; subglacial at } \\
\text { base }\end{array}$ \\
\hline & & & $\begin{array}{c}\text { W2 } \\
\text { (Middle } \\
\text { Carbonate) }\end{array}$ & $\begin{array}{l}20- \\
30\end{array}$ & $\begin{array}{l}\text { Three main intervals of } \\
\text { carbonate-bearing sandstones } \\
\text { and siltstones with intervening } \\
\text { diamictites }\end{array}$ & $\begin{array}{l}\text { Carbonate intervals are fluvial } \\
\text { and lacustrine with glacial } \\
\text { influence; diamictites are } \\
\text { glacilacustrine rainout deposits }\end{array}$ \\
\hline & & & $\begin{array}{c}\text { W1 } \\
\text { (Ormen) }\end{array}$ & $\begin{array}{l}55- \\
85\end{array}$ & $\begin{array}{l}\text { Brecciated underlying dolomite } \\
\text { locally overlain by sandstones } \\
\text { and conglomerates passing up } \\
\text { into diamictites and } \\
\text { sandstones with local } \\
\text { rhythmites }\end{array}$ & $\begin{array}{l}\text { Basal periglaciated surface, } \\
\text { locally succeeded by fluvial } \\
\text { deposits, then glacilacustrine } \\
\text { rainout deposits and sediment } \\
\text { gravity flows }\end{array}$ \\
\hline & & \multirow{4}{*}{$\begin{array}{c}\text { Elbobr } \\
\text { een }\end{array}$} & $\begin{array}{c}\text { E4 } \\
\text { (Slangen) }\end{array}$ & $\begin{array}{l}20- \\
30\end{array}$ & Oolitic dolomite & Regressive peritidal \\
\hline & & & $\begin{array}{c}\text { E3 } \\
\text { (Macdonaldr } \\
\text { yggen) }\end{array}$ & 200 & $\begin{array}{l}\text { Finely laminated dolomitic silty } \\
\text { shale }\end{array}$ & Offshore marine \\
\hline & & & $\begin{array}{c}\text { E2 } \\
\text { (Petrovbree } \\
\text { n) }\end{array}$ & $\begin{array}{l}10- \\
20\end{array}$ & $\begin{array}{l}\text { Dolomitic diamictites, } \\
\text { rhythmites and conglomerates }\end{array}$ & Glacimarine \\
\hline $\begin{array}{l}\text { (base to } \\
\text { be } \\
\text { defined) }\end{array}$ & & & E1 (Russøya) & $\begin{array}{l}75- \\
170\end{array}$ & $\begin{array}{c}\text { Dolomites overlain by } \\
\text { limestone with molar tooth } \\
\text { structure, black shale and } \\
\text { dolomite }\end{array}$ & Shallow marine \\
\hline
\end{tabular}

This article is protected by copyright. All rights reserved. 


\begin{tabular}{|c|c|c|c|c|}
\hline \multirow{4}{*}{ 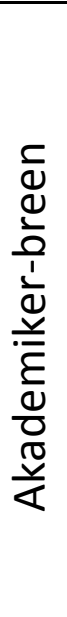 } & $\begin{array}{l}\text { Backlu } \\
\text { nd- } \\
\text { toppen }\end{array}$ & 530 & Limestone and dolomite & Carbonate platform \\
\hline & Draken & 350 & Intraclastic dolomite & Peritidal \\
\hline & $\begin{array}{l}\text { Svanbe } \\
\text { rg- } \\
\text { fjellet }\end{array}$ & 425 & Limestone and dolomite & Carbonate platform \\
\hline & $\begin{array}{l}\text { Grusdi } \\
\text { ev- } \\
\text { breen }\end{array}$ & 700 & Limestone and dolomite & Carbonate platform \\
\hline
\end{tabular}

Table 2. Summary of characteristics of carbonates in members W1 and W3. Analyses are of calcite except where italicized (dolomite): $\mathrm{s}=$ standard deviation; $\mathrm{n}=$ number of samples.

\begin{tabular}{|c|c|c|c|c|c|c|c|c|}
\hline \multirow[b]{2}{*}{ Section } & \multirow{2}{*}{$\begin{array}{l}\text { Member, m } \\
\text { above } \\
\text { member base } \\
\text { (from member } \\
\text { top) }\end{array}$} & \multirow[b]{2}{*}{$\begin{array}{l}\text { Facies } \\
\text { association }\end{array}$} & \multirow[b]{2}{*}{ Lithology } & \multicolumn{2}{|c|}{$\delta^{18} 0$} & \multicolumn{2}{|c|}{$\delta^{13} \mathrm{C}$} & \\
\hline & & & & mean & $\mathrm{s}$ & mean & $\mathrm{s}$ & $\mathrm{n}$ \\
\hline \multirow{3}{*}{ AND } & & & Intraclastic stromatolitic rhythmites (carbonate layers 5 to & & & & & \\
\hline & W3 $30(-15)$ & & $10 \mathrm{~mm}$ thick) with intervening diamictite. Some calcite- & & & & & \\
\hline & & 5 & filled pseudomorphs & -9.22 & 0.20 & 0.27 & 0.33 & 5 \\
\hline \multirow[t]{2}{*}{ AND } & W3 $38(-7)$ & & $\begin{array}{l}\text { Stromatolitic limestone (laminae } 5 \text { to } 10 \mathrm{~mm} \text { thick) with } \\
\text { diamictite laminae, variably broken up within diamictite. }\end{array}$ & & & & & \\
\hline & & 5 & Observed over 100 m laterally & -8.16 & 0.55 & 0.23 & 0.70 & 6 \\
\hline \multirow{2}{*}{ AND } & W3 40.5 (- & & & & & & & \\
\hline & $4.5)$ & 5 & Brecciated limestone & - & - & - & - & - \\
\hline \multirow[t]{2}{*}{ REIN } & W3 $56(-6.5)$ & 5 & Limestone with scattered sand & -8.92 & - & -0.44 & - & 1 \\
\hline & & & Carbonates interlaminated with diamictite at base of bed. & -7.97 & - & 1.83 & - & 1 \\
\hline \multirow[t]{2}{*}{ KLO } & W3 $25(-18)$ & 5 & $\begin{array}{l}\text { EFK15 closely resembles the middle carbonate layer at } \\
\text { section AND }\end{array}$ & -5.03 & - & 1.04 & - & 1 \\
\hline & W3 $28(-15)$ & 5 & $\begin{array}{l}\text { Laminated carbonates in diamictite. Some crystal } \\
\text { pseudomorphs both within sediment and growing }\end{array}$ & -8.86 & 0.40 & -0.38 & 0.10 & 3 \\
\hline $\mathrm{KLO}$ & & & upward & -4.04 & - & 1.16 & - & 1 \\
\hline $\mathrm{KLO}$ & & 5 & dolomite) of ikaite & -9.44 & 2.38 & 0.31 & 1.09 & 4 \\
\hline KLO & W3 $35(-8)$ & 5 & Similar to horizon $4 \mathrm{~m}$ lower in section & - & - & - & - & - \\
\hline PIN & W3 n/a (-26) & 5 & $\begin{array}{l}\text { Slump folded and brecciated thickly laminated } \\
\text { stromatolitic limestone in red silty sandy diamictites. }\end{array}$ & - & 0.28 & -0.04 & 0.29 & 3 \\
\hline
\end{tabular}

This article is protected by copyright. All rights reserved. 


\begin{tabular}{|c|c|c|c|c|c|c|c|c|}
\hline & & & Traceable laterally for $30 \mathrm{~m}$ & 12.53 & & & & \\
\hline ORM & $\begin{array}{l}\text { W1 } 3.5 \text { (- } \\
20.5)\end{array}$ & 5 & $\begin{array}{c}\text { Slump-folded rhythmites with distinct millimetre-scale } \\
\text { stromatolitic limestone laminae, some with bulbous tops, } \\
\text { separated by diamictite }\end{array}$ & -12.5 & - & 0.32 & - & 2 \\
\hline ORM & W3 $28(-30)$ & 3 & $\begin{array}{l}\text { Sandstone with convolute bedding with nodular dolocrete } \\
\text { (floating quartz, micro-nodules and cracks) along specific } \\
\text { laminae }\end{array}$ & +6.78 & - & 5.60 & - & 2 \\
\hline ORM & W3 $33(-25)$ & 4 & $\begin{array}{l}\text { Diamictite rests on massive stromatolitic limestone with } \\
\text { pseudomorphs and slump folds or intraclasts over } \\
\text { greenish cross-laminated sandstone with ooids }\end{array}$ & $\begin{array}{r}- \\
10.76\end{array}$ & 1.12 & 2.20 & 1.56 & 6 \\
\hline ORM & $\begin{array}{l}\text { W3 } 46.5 \text { (- } \\
11.5)\end{array}$ & 5 & $\begin{array}{c}\text { Red, thickly laminated and slump-folded stromatolitic } \\
\text { limestone in diamictite. Locally massive with lot of early } \\
\text { cement }\end{array}$ & -9.44 & 2.38 & 0.31 & 1.09 & \\
\hline
\end{tabular}

Table 3. Facies and facies associations of the Wilsonbreen Formation. The facies associations are numbered to represent an environmental continuum as depicted in Fig. 6.

\begin{tabular}{|c|c|c|}
\hline Facies association & Constituent facies & Environmental interpretation \\
\hline $\begin{array}{l}\text { FA1: Deformed } \\
\text { Diamictite - } \\
\text { Detailed facies } \\
\text { analysis in Fleming } \\
\text { et al. (2016) }\end{array}$ & $\begin{array}{l}\text { Dominated by massive diamictites, locally with } \\
\text { deformed stratification with lenticular sand and gravel } \\
\text { bodies ( } 1 \text { to } 5 \mathrm{~m} \text { thick) with disrupted margins. Locally } \\
\text { associated with upward-increasing shear of underlying } \\
\text { sediment and striated boulder pavements }\end{array}$ & $\begin{array}{l}\text { Subglacial till and channel bodies; } \\
\text { glacitectonites }\end{array}$ \\
\hline $\begin{array}{l}\text { FA2: Fluvial } \\
\text { Channel }\end{array}$ & $\begin{array}{l}\text { 2S: Beds of } 0.5 \text { to } 4.0 \mathrm{~m} \text { very fine to medium-grained, } \\
\text { locally cross-stratified sandstone with erosional } \\
\text { conglomeratic base. Some variants have low-angle } \\
\text { accretion surfaces with silt-dominated beds. } \\
\text { Stromatolitic limestone is either absent or abundant, } \\
\text { forming decimetre scale packages with millimetre to } \\
\text { centimetre-scale laminae separated by sand laminae } \\
\text { and laterally eroded into trains of intraclasts } \\
\text { 2T: As above, but lacking carbonate precipitates }\end{array}$ & $\begin{array}{l}\text { Ephemeral stream channel sands with } \\
\text { strongly seasonal flows. In some cases } \\
\text { there is a widespread carpet of calcified } \\
\text { microbial mats }\end{array}$ \\
\hline $\begin{array}{l}\text { FA3: Dolomitic } \\
\text { Floodplain }\end{array}$ & $\begin{array}{l}\text { All facies contain dolomite with a positive } \delta^{18} \mathrm{O} \\
\text { composition that actively cements, displaces and/or } \\
\text { upwardly accretes the sediment } \\
\text { 3D: Nodules, centimetre to decimetre-scale of dolomite- } \\
\text { cemented silts and sands transitional to structureless } \\
\text { decimetre to metre-scale beds with floating silt and } \\
\text { sand in dolomite, internal nodules and calcite-cemented } \\
\text { fractures } \\
\text { 3S: Stromatolitic dololaminites, decimetre-scale and } \\
\text { millimetre-laminated }\end{array}$ & $\begin{array}{l}\text { Dolocretes representing soil horizons, } \\
\text { typically above fluvial deposits, with } \\
\text { locally raised water table } \\
\text { 3N: Nodular dolocrete } \\
\text { 3D: Bedded dolocrete } \\
\text { 3S: Subaerial stromatolites }\end{array}$ \\
\hline FA4: Calcareous & 4R: Rhythmites with millimetre-scale dolomite, & 4R: Shallow lake to playa environment \\
\hline
\end{tabular}

This article is protected by copyright. All rights reserved. 


\begin{tabular}{|c|c|c|}
\hline Lake Margin & $\begin{array}{l}\text { limestone or mixed mineralogy laminae, commonly } \\
\text { desiccated, alternating with } 1 \text { to } 10 \text { mm wavy cross- } \\
\text { laminated silty sandstones. Carbonate laminae are often } \\
\text { stromatolitic. Almost invariably reddened } \\
4 \mathrm{I} \text { : Intraclastic, decimetre-scale, very fine to medium- } \\
\text { grained sandstones. Very locally contain ooids } \\
\text { 4S: Indistinctly horizontally stratified well-sorted fine to } \\
\text { medium-grained sandstone, with well-rounded grains, } \\
\text { locally with centimetre-scale dolomite laminae }\end{array}$ & $\begin{array}{l}\text { with wave-reworked sediment } \\
\text { alternating with microbial mat accretion } \\
\text { 4I: Discrete storm horizons in shallow } \\
\text { lake/playa reworking sand and } \\
\text { stromatolitic carbonate } \\
\text { 4S: Aeolian sandflat deposits }\end{array}$ \\
\hline $\begin{array}{l}\text { FA5: Carbonate } \\
\text { Lake }\end{array}$ & $\begin{array}{l}\text { 5R: Rhythmites with millimetre-scale limestone, } \\
\text { dolomite or mixed mineralogy laminae, usually with } \\
\text { stromatolitic microstructure and locally building } \\
\text { decimetre stromatolites with centimetre-scale relief. } \\
\text { Alternate with } 0.1 \text { to } 5.0 \mathrm{~mm} \text { laminae of } \\
\text { diamictite/wacke, commonly with till pellets and } \\
\text { occasional lonestones. Slump folding and brecciation } \\
\text { common } \\
\text { 5D: Discrete gravel to diamictite units with significant } \\
\text { intraclastic debris in addition to terrigenous gravel }\end{array}$ & $\begin{array}{l}\text { 5R: Carbonate microbial mat deposits in } \\
\text { lacustrine environment subject to } \\
\text { seasonal ice-rafting and slope instability }\end{array}$ \\
\hline $\begin{array}{l}\text { FA6: } \\
\text { Glacilacustrine - } \\
\text { Detailed facies } \\
\text { analysis in Fleming } \\
\text { et al. (2016) }\end{array}$ & $\begin{array}{l}\text { Dominated by massive and stratified diamictites with } \\
\text { common lonestones and till pellets. Decimetre to metre- } \\
\text { scale intervals of silty rhythmites occur locally, especially } \\
\text { in member W1. May contain lenses of conglomerate, } \\
\text { sometimes channelled, and lenses or thin beds of } \\
\text { sandstone forming packages which can be inclined at up } \\
\text { to } 20^{\circ}\end{array}$ & $\begin{array}{l}\text { Ice-rafted glacilacustrine sediment locally } \\
\text { reworked as sediment-gravity flows. } \\
\text { Inclined packages form grounding-line } \\
\text { fans (termed proximal glacilacustrine on } \\
\text { Fig. 1) and rhythmites likewise reflect } \\
\text { ice-margin retreat }\end{array}$ \\
\hline $\begin{array}{l}\text { FA7: Periglacial - } \\
\text { See Fairchild \& } \\
\text { Hambrey (1984) } \\
\text { and Benn et al. } \\
\text { (2015) }\end{array}$ & $\begin{array}{l}\text { Decimetre-wide sandstone wedges penetrating up to } 2 \\
m \text { into underlying sediment from a discrete surface that } \\
\text { may have a gravel lag. At base of Wilsonbreen } \\
\text { Formation, gravel with ventifacts overlying shattered } \\
\text { dolostone }\end{array}$ & $\begin{array}{l}\text { Exposed periglaciated bedrock and sand } \\
\text { wedges from exposed periglacial } \\
\text { environment }\end{array}$ \\
\hline
\end{tabular}

\section{Figure Captions}

Fig. 1. Reconstruction of the sedimentary architecture and palaeoenvironments of the Wilsonbreen Formation and its constituent members (W1 to W3). Precipitated carbonate is present in the palaeoenvironmental group called 'Carbonate Lacustrine and Fluvial' throughout W2 (except locally at the top and base), also in W3 and at one of the locations in W1 as listed in Table 2. The Svalbard archipelago is shown bottom right and Spitsbergen is the main island of the group, whilst

This article is protected by copyright. All rights reserved. 
Nordaustlandet is the island to the north-east. The rectangle on the Svalbard map shows the study area as enlarged upper right with Wilsonbreen Formation outcrops (red) within nunataks (grey) rising from the highland snowfield. From north to south, study locations are: DRA (Dracoisen); here the main section is located on a nunatak informally known as Multikolorfjellet with some additional sampling from W2 at a second nunatak termed Tophatten $1 \mathrm{~km}$ to the north; DIT (Ditlovtoppen); AND (East Andromedafjellet); REIN (a ridge on South Andromedafjellet informally known as Reinsryggen); KLO (South Klofjellet); with some additional observations from a partial W2 section 1 km away, at North Klofjellet; McD (MacDonaldryggen); GOL (Golitsynfjellet, intermediate between McD and BAC) - a partial W2 section was illustrated by Fairchild et al. (1989); BAC (BacklundtoppenKvitfjellet ridge); PIN (an unnamed nunatak informally termed Pinnsvinryggen); SLA (Southeast Slangen ) and ORM (South Ormen).

Fig. 2. Examples of studied section outcrops. (A) Member W2 at Multikolorfjellet, Dracoisen (DRA) illustrating the three groups of glacial retreat facies beds (numbered ' 1 ' to ' 3 ') separated by diamictites which also make up members W1 and W3. (B) Member W2 at ORM (South Ormen) with pale sand-dominated units and dark red finer units. Bedding is inverted and dips steeply away from the photographer. (C) REIN (Reinsryggen) section on the south flank of Andromedafjellet illustrating Wilsonbreen Formation members overlain by cap carbonate member D1. (D) KLO (South Klofjellet) section of the entire Wilsonbreen Formation on steep slopes cut by minor faults, one of which is highlighted. (E) BAC (Backlundtoppen-Kvitfjellet ridge) photomontage from helicopter hovering above the glacier Wilsonbreen. The visible section is vertical (thrust fault shown) and the accessible part defines a narrow ridge between the cliff and a snowbank on the ridge crest.

Fig. 3. (A) Oblique aerial view of the McMurdo Dry Valleys (01/01/1999 imagery from US Geological Survey via Google Earth) with location arrowed in inset of Antarctica (upper right). EAIS = East Antarctic Ice Sheet. LGM = Last Glacial maximum. Abbreviations on upper right inset: $E A=$ East This article is protected by copyright. All rights reserved. 
Antarctica, WA =West Antarctica, RIS = Ross Ice Shelf. The lower left inset shows an oblique aerial photograph looking west up Taylor Valley with cold-based valley glaciers on hillside on left, icecovered Lake Bonney (valley floor, right ) with the tip of the Taylor Glacier beyond. (B) Despite subzero temperatures, runoff occurs from the Lower Wright Glacier (an outlet glacier of the coastal Wilson Piedmont Glacier) and feeds the Onyx River. This stream flows inland to the west, eventually to Lake Vanda, visible in (A) in the central part of the valley. Note the aeolian sands banked agains the glacier. (C) Oblique aerial view of Victoria Lower Glacier (eastern end of Victoria Valley) which feeds a stream flowing inland, westward to Lake Vida, seen in the distance. Aeolian dunes tranverse to the stream are visible on right-side of the the valley.

Fig. 4. Profile of member W2 at Dracoisen. The lithological log emphasizes physical characteristics (see key, upper right) whilst the assignment to facies associations (centre) also draws on petrological and stable isotope information. FA1 to FA6 represent an environmental continuum (cf. Fig. 7) and FA7 is grouped with FA1 as the terrestrial glacial end-member. Each datapoint (bar on thick black line) represents the stratigraphic position of a studied sample or observed lithological boundary in the field. The oxygen isotope composition of precipitated calcites and dolomites (the latter adjusted by $-3 \%$ ) are shown. Mixed-mineralogy samples ( $<90 \%$ calcite or dolomite in calcite-dolomite mixtures) are not plotted. The same conventions are used for profiles of the other studied sections, which are presented as supporting figures (Figs S1 to S6).

Fig. 5. Detrital textures and minerals. (A) and (B) Paired images of a polished thin section under CL and in transmitted light respectively of the matrix of a silty sandstone (W2, $81.2 \mathrm{~m}$, Dracoisen) illustrating the abundance of faint blue-luminescing feldspar and varied fragments of both bright and dull red-luminescing dolomite in the mud fraction. (C) Thin section, transmitted light. Siltstone graded rhythmites (W3, 60.4 m, East Andromedafjellet) displaying several sand-sized till pellets. (D)

This article is protected by copyright. All rights reserved. 
Crossed polars. Matrix at the top of a graded silt layer illustrating quartzo-feldspathic debris and micron-sized dolomite, but no clay minerals (W1, 10 m Slangen).

Fig. 6. (A) Summary of stable isotope compositions of precipitated carbonate. Inset gives detail of compositions of clasts and fine dolomite matrix. Dolomite and calcite groupings are separated and only samples with $>90 \%$ of either dolomite or calcite in the carbonate fraction are plotted. (B) Stable isotope fields illustrating degree of covariance of the sample groups.

Fig. 7. Summary cartoon of facies associations. Facies Associations 2 to 5 are colour-coded here and in isotope plots. The margin of an ice sheet is depicted, terminating partly on land and, in the foreground, in the lake. Facies Association 1 is shown in a subglacial environment (subglacial sediments are coloured brown); periglacial phenomena are also grouped in this facies association. Facies Associations 2 and 3 both occur in a fluvial setting (sediments coloured yellow), whilst FA5 and FA6 were deposited in lakes (sediments coloured light brown). Facies Association 4 includes both shallow lacustrine and coastal sediments.

Fig. 8. Facies association 2 (Fluvial Channel). (A) to (F) are Facies $2 S$ (W2, Dracoisen, at around the $60 \mathrm{~m}$ level), whereas (G) and $(\mathrm{H})$ are facies $2 \mathrm{~T}$. (A) Sandstone with microbial laminites and lowdomed stromatolites variably broken into intraclasts. (B) Stained thin section in transmitted light of stromatolite microstructure with micrite ' $M$ ', microspar ' $S$ ', fenestral ' $F$ ' and detrital ' $D$ ' laminae. (C) Stained thin section in transmitted light showing the broken edges of stromatolitic intraclasts with radiaxial calcite cement crusts in a calcareous sandstone matrix. (D) Cross-stratified sandstone (set $30 \mathrm{~cm}$ high) with stromatolite intraclasts overlain by current ripple forms. (E) Polished rock slice with arrow denoting micromilled traverse shown in (F). (F) Micromill isotope traverse across two micrite/microspar lamina and a central zone of calcite spar which has a much lower isotope signature. (G) Sandstone body (with pebbly base) showing accretionary surfaces (for example, This article is protected by copyright. All rights reserved. 
dashed line). Palaeohorizontal shown by solid black line. (W2, Ditlovtoppen, 119 m). (H)

Photomontage of tabular sandstone unit of FA2 with a pebble horizon near its top (arrowed). It rests erosively on floodplain (FA3) silts and is overlain by red lake margin (FA4) sediments; ruler is $25 \mathrm{~cm}$ long (W2, Dracoisen, $83 \mathrm{~m}$ ).

Fig. 9. Photomicrographs of stromatolitic limestones from FA2. (A. Paired transmitted light (left)and $\mathrm{CL}$ (right) micrographs. Stromatolitic laminae of orange-luminescing microspar (MS) with subhedral authigenic quartz and clastic layer (M) including quartz and feldspar grains (the latter luminesces dark blue). Large fenestra is filled by radiaxial calcite $(R)$ seen in both transverse and basal sections and displaying brighter earlier growth and duller later growth. These fabrics are cut by a vein (V) filled with bright to dull luminescing calcite. W2, Dracoisen, $58.5 \mathrm{~m}$. (B. Stained thin section, transmitted light. Alternating micrite, microspar and clastic laminae with prominent irregular vertical "filamentous" structure of clear calcite. W2, Dracoisen, $58.5 \mathrm{~m}$.

Fig. 10. FA3 (Dolomitic floodplain). Facies 3D is shown in (A) to (D), Facies $3 S$ in the others, and both facies in (E). All of the Facies 35 images come from W2, Dracoisen, 70 m. (A) Nodular dolocrete with calcite-lined vugs in siltstone with scale in millimetres (W2, East Andromedafjellet, $35 \mathrm{~m}$ ). (B) Stained thin section in plane polarized light showing matrix-supported fabric of dolomite cementation of sandy siltstone. Dolomicrospar lines a fenestra which is occluded by calcite. W2, Dracoisen, $70 \mathrm{~m}$. (C) Thin section in plane polarized light. Grain-supported dolomicrite cement of silty sandstone. The dolomite has a $\delta^{18} \mathrm{O}$ composition of $+2.7 \%$ and has a uniform texture in contrast to clastic dolomite of Fig. 4D. W2, South Klofjellet, 57 m. (D) Displacive dolomite cement supporting silt and sand grains. Well-developed structure of dark nodules which show different $\mathrm{CL}$ characteristics from surrounding dolomite from which they are separated by curved cracks. W3, South Ormen, $78 \mathrm{~m}$. (E) Stained thin section of interlaminated dolomite-cemented sand and microbial laminae with fenestrae, some occluded by ferroan dolomite (turquoise arrow) or ferroan calcite (purple arrow). (F) Stained thin

This article is protected by copyright. All rights reserved. 
section illustrating similar fabric to (D), but with calcite cementation of cracks and larger pores (W2, Dracoisen, $83 \mathrm{~m}$ ) (G) Field photograph of textured bedding surface of dololaminite identified as microbial mat texture (W2, Dracoisen, $70 \mathrm{~m}$ ). (H) Polished rock chip of microbial dololaminites with arrow marking position of $5.2 \mathrm{~mm}$ micromill traverse [shown in (J) below].( I) Microbial laminites draping downward into underlying laminate whose brecciation is attributed to evaporite dissolution collapse. Outlined ruler is $20 \mathrm{~cm}$ long. (J) Stable isotope profile (in \%o with respect to V-SMOW) of microbial dololaminites along line illustrated in $(\mathrm{H})$ The isotopes covary over a magnitude of $6 \%$ for $\delta^{18} \mathrm{O}$ and $1 \%$ for $\delta^{13} \mathrm{C}$.

Fig. 11. FA3 (dolomitic floodplain). (A) Transmitted light, stained thin section. Sandy dolocrete (FA3) containing equant nodule cemented by ferroan saddle dolomite (turquoise), with local late calcite (red), interpreted as a fill of a small anhydrite nodule. W2, Backlundtoppen-Kvitfjellet ridge, $74.7 \mathrm{~m}$. (B) Facies 35 stromatolite with fenestrae. Paired transmitted light (left) and CL (right) images. Brightly luminescing dolomite may be primary or an early replacement of a precursor. W2, Dracoisen 69.95 m. (C) Paired transmitted light (left) and CL (right) images. Dolocrete showing very fine-grained quartz sand grains floating in dolo(micro-)spar with crystals displaying a common zonation of bright to dull CL. Displacive primary dolomite growth is the preferred interpretation. W2, Ditlovtoppen, 118.5 m. (D) Paired transmitted light (left) and CL (right) images. Dolocrete, similar to Fig. 10D and F, with sparse floating quartz and feldspar (black and blue respectively in $\mathrm{CL}$ ) and calcite-filled cracks(centre) and pores (base). Uniformly luminescing dolomicrite crystals, differ in brightness within nodules presumably forming at different stages. Calcite-filled pores show CL zonation (base) or no $\mathrm{CL}$ (cracks, centre). W2, Dracoisen, $82.9 \mathrm{~m}$.

Fig. 12. Stable isotope plot, differentiating facies within FA3 and (in purple and larger symbols) samples from member W3.

This article is protected by copyright. All rights reserved. 
Fig. 13. FA4 (Calcareous Lake Margin). Images (A), (B), (D) and (H) to (J) are Facies 4R; (C), (E) and (G) are Facies $4 \mathrm{I}$ and (F) is Facies 4S. (A) Laminated rhythmic limestones and silty sandstones with conspicuous isolated wave ripple structure in centre of view. W2, Dracoisen, $90 \mathrm{~m}$. (B) Sand-rich example of facies $4 R$ with cross-laminated silty sands and dolomitic rhythmites, in part desiccated or eroded to form intraclasts. White areas near top are mineral (probable salt) pseudomorphs. W2, Ditlovtoppen, $109 \mathrm{~m}$. (C) Wave ripples with $15 \mathrm{~cm}$ wavelength on bed top W2, Dracoisen (Tophatten), approximately equivalent to the $87 \mathrm{~m}$ level on Fig. 4. (D) Carbonate rhythmite surface cut by desiccation cracks and bearing salt pseudomorphs. W2, Reinsryggen, $82.5 \mathrm{~m}$. (E) Stained thin section, plane polarized light of oolitic intraclastic sandstone. Ooids are bimineralic (calcite and dolomite) with dominant concentric structure. W3, South Ormen, $84 \mathrm{~m}$. (F. Part of scanned thin section in transmitted light. Well-sorted quartzose sandstone with very well-rounded grains and lowangle lamination marked by subordinate interstitial dolomite. W2, Ditlovtoppen, $114.2 \mathrm{~m}$. (G) Stained thin section in transmitted light. Sandstone with conspicuous stromatolitic rhythmite limestone intraclasts. W2, Backlundtoppen-Kvitfjellet ridge, 76.5 m (Fig. S6). (H) Two-metre high section at of Ditlovtoppen (108.5 to 110.5 on supplementary figure 1 ) showing poorly stratified sandstone bed (Facies 4S) overlying Facies 4R with several discrete graded intraclastic sandstone beds (Facies 4I).(I) Polished slab of dolomitic rhythmites with desiccation cracks (C). The $3.2 \mathrm{~mm}$ long micromill isotope traverse of $(\mathrm{J})$ is indicated. W2, South Ormen, $31.3 \mathrm{~m} .(\mathrm{J})$ Isotope results from the micromill traverse with lighter isotope values corresponding to detrital dolomite matrix and the heaviest values (at right) indicative of precipitated dolomite composition.

Fig. 14. FA4 illustrating contrast between detrital and replacive dolomite. (A) and (B) Paired transmitted light and CL images respectively. Enlargement of the boundary between a dolomicrite lamina (below) and a detrital lamina (top) of the same sample as in Fig. 13I and J. The detrital layer shows quartz (black in CL), feldspar (blue), a dolomite clast (bright ring) whilst the dolomicrite shows a consistent zonation of crystals with a bright core as well as some fine silt-sized siliciclastic debris.

This article is protected by copyright. All rights reserved. 
The dolomicrite is interpreted as an early diagenetic replacement of an early carbonate phase. W2, South Ormen, $31.3 \mathrm{~m}$.

Fig. 15. Facies Association 5 (Calcareous Lake) in member W2. All illustrate Facies $5 R$, but transitions to Facies 5D are shown in (D) and (E). (A) Thin section in transmitted light. Calcareous rhythmites with subordinate clastic sediment including till pellets (for example, yellow arrows). White areas, 1 to $2 \mathrm{~mm}$ across, are mineral pseudomorphs. Reinsryggen, $81 \mathrm{~m}$. (B) Calcareous rhythmites with irregular lamina tops indicative of microbial structure and growth domes above vuggy areas with syn-depositional calcite cements. Note scale in millimetres. Reinsryggen, $80.5 \mathrm{~m}$. (C) Sawn and polished hand specimen illustrating a growth fault across which the stratigraphy of stromatolitic rhythmite layers changes. Note scale in centimetres. East Andromedafjellet, $30.3 \mathrm{~m}$ - note this is a thin rhythmite occurrence within diamictite (supporting Fig. 1). (D) Stained thin section in transmitted light. Dolomite dropstone ' $d$ ' deforms underlying limestone rhythmite and lies at the base of a coarser resedimented layer including limestone intraclasts. Ditlovtoppen, $108 \mathrm{~m}$. (E) Lower half of a discrete $40 \mathrm{~cm}$ diamictite debris flow unit with rhythmites deformed by slumping at the base. Numerals $1 \mathrm{~cm}$ apart on tape, lower right corner. Ditlovtoppen, $109 \mathrm{~m}$ (wedging out over 100 $m$ to the section shown in supporting Fig. 1). (F) Stromatolitic rhythmites, alternately pure white and impure sediment-bearing limestone. Backlundtoppen-Kvitfjellet ridge, $77 \mathrm{~m}$. Location of micromill traverse of (G) illustrated. (G) Micromill traverse as in (F) illustrating a systematic shift in $\delta^{18} \mathrm{O}$, but within a relatively narrow range of $1 \%$, similar to range of uncorrelated variation in $\delta^{13} \mathrm{C}$.

Fig. 16. Facies Association 5 (calcareous lake) in members W3 and W1. All show Facies $5 R$ with various transitions to Facies 5D. (A) Diamictites of faces association 6 becoming interlaminated (yellow arrows) with limestone rhythmites. Slump folds in upper left. Lens cap for scale. W3, South Klofjellet, $116.5 \mathrm{~m}$. (B) Limestone rhytmites developing slump folds upward and transitioning to an intraclastic diamictite. W3, South Klofjellet, 116.5 m. (C) Polished hand specimen illustrating

This article is protected by copyright. All rights reserved. 
erosional truncation of stromatolitic rhythmite laminae by diamictite with prominent centimetrescale pebbles. W3, South Klofjellet, 120 m. (D) Thin section in transmitted light of partly brecciated rhythmite with laminae up to centimetre-scale with interstitial ice-rafted sediment. Equant white areas a few millimetres across are mineral pseudomorphs. W3, East Andromedafjellet, $63 \mathrm{~m}$. (E) Slump-folded 1 to $3 \mathrm{~mm}$ limestone rhythmite layers with interstitial green ice-rafted sediment. Scale is in centimetres. This is the only precipitated carbonate horizon in W1 (South Ormen, $3.5 \mathrm{~m}$ ).

Fig. 17. Crystal fabrics in FA5. (A) Transmitted light. Millimetre-scale microbial calcite laminites separated by thinner ice-rafted laminae and locally containing till pellets (P). Calcite laminites display peloidal clots and local fenestrae and have variably bulbous tops. W2, Reinsryggen, $79.8 \mathrm{~m}$. (B) Transmitted light. Similar horizon to (C) displaying clastic lamina overlain by clotted and fenestral microbial lamina with bulbous top. W2, East Andromedafjellet, $13.5 \mathrm{~m}$. (C) Stained thin section, transmitted light. Dolomitic microbial laminite containing dolomicrite and dolomicrospar laminae and floating detritus (white). Conspicuous fenestrae are filled by pink-stained calcite. W2, South Ormen, 31.4 m. (D) Transmitted light. W2, Reinsryggen, 79.8 m, microbial fabrics. Faintly clotted (peloidal) micrite (examples arrowed) and microspar laminae with intervening calcite-filled fenestra. Dark patches are micro-till pellets (some are labelled ' $P$ '), now partly silicified. (E) Transmitted light, stained thin section. Enlargement of the ikaite pseudomorphs of Fig. 18B showing relic crystal outlines in dark micrite and replacive calcite (micro-)spar mosaic of zoned euhedral non-ferroan calcite overgrowth by ferroan calcite. W3, South Klofjellet, 116.5 m. (F) Paired transmitted light (left) and CL (right) images. Fenestral microbial fabric similar to Fig. 17D displaying consistent crystal zonation: brighter to duller in micritic matrix and sharper zones within fenestral cements. Fabric is consistent either with primary calcite growth within extracellular polymeric substance or replacement of ikaite, followed by cementation of fenestrae. W2, Reinsryggen, $80.6 \mathrm{~m}$.

This article is protected by copyright. All rights reserved. 
Fig. 18. Crystal pseudomorphs. (B) to (G) are all FA5. (A) Permian glendonite from South Australia: ikaite pseudmorphs that original grew in glacimarine mudrocks. Pencil for scale. Sample provide by Malcolm Wallace. (B) Transmitted light view of interlaminated diamictites and laminated limestones, microbial in part, and displaying two distinct horizons of upward-growing crystals. Crystals influence subsequent sedimentation pattern and hence grew into the water column. W3, South Klofjellet, $116.5 \mathrm{~m}$. (C) Histogram of apparent interfacial angles from thin sections of samples shown in (B). Modes are most consistent with an ikaite precursor (see text) (D) Transmitted light, stained thin section of same sample as (B). Pseudomorphs are composite of mosaics of zoned, mostly ferroan (bluish) calcite crystals. Outer edges of crystals have in part been dissolved and in part silicified. W3, South Klofjellet, 116.5 m. (E) Transmitted light. Calcite-cemented crystal pseudomorphs, morphology consistent with ikaite, in stromatolitic limestone . W3, South Ormen, 85 m. (F) Transmitted light. Indistinct calcite-cemented probably ikaite pseudomorphs, morphology probably consistent with ikaite, in stromatolitic limestone. W2, Reinsryggen, 81.2 m. (G) Transmitted light. Dolorhythmites hosting dolomite pseudomorphs, inferred to be after ikaite, with varying micrite-microspar-spar replacive textures. W2, North Klofjellet, $67 \mathrm{~m}$.

Fig. 19. Wilsonbreen crystal pseudomorphs (A) compared with ikaite crystals (C) and pseudomorphs of different ages and contexts (B), (D) and (E). (A) Polished hand specimen (same sample as Fig. 16B. Note small pink pebble to left in diamictite layer overlying top crystal layer. Crystals grew upward at three horizons and were draped by overlying sediments before being replaced by calcite as illustrated in Figs 18D and 20A. W3, South Klofjellet, 116.5 m. (B) Examples of 'thinolite' crystals from Dana (1884), interpreted as ikaite pseudomorphs by Shearman et al. (1989). Scale not given in the original, but crystals are typically centimetre to decimetre-scale. (C) Profiles of ikaite crystals recovered from Arctic sea ice by partial melting (Nomura et al., 2013). (D) and (E) ikaite pseudomorphs from a Patagonian lake (Oeherlich et al., 2013). (D) illustrates crystals with equant

This article is protected by copyright. All rights reserved. 
habit and stepped faces as seen by scanning electron microscopy. (E) illustrates pseudomorphs attached to moss filaments.

Fig. 20. Vertical (upward) facies transitions in member W2. For this purpose FA1 and FA7 are conflated. The width of the arrows is proportional to the number of transitions minus one. The transition matrix shown in supporting Fig. 8 indicates that at least one vertical transition occurs between each of the facies associations except FA1. See text for discussion.

Fig. 21. Relative thickness of strata belonging to the different facies associations in the five sections with comparably thick carbonate facies preserved in W2, from south to north. See text for discussion and abbreviations in Fig. 1.

Fig. 22. Diagrammatic summary of the processes responsible for variation in isotope composition of the Wilsobreen carbonate and interpretations of their parageneses with (at base) a cartoon environmental profile. Large numbers refer to Facies Associations 2 to 5.

This article is protected by copyright. All rights reserved. 


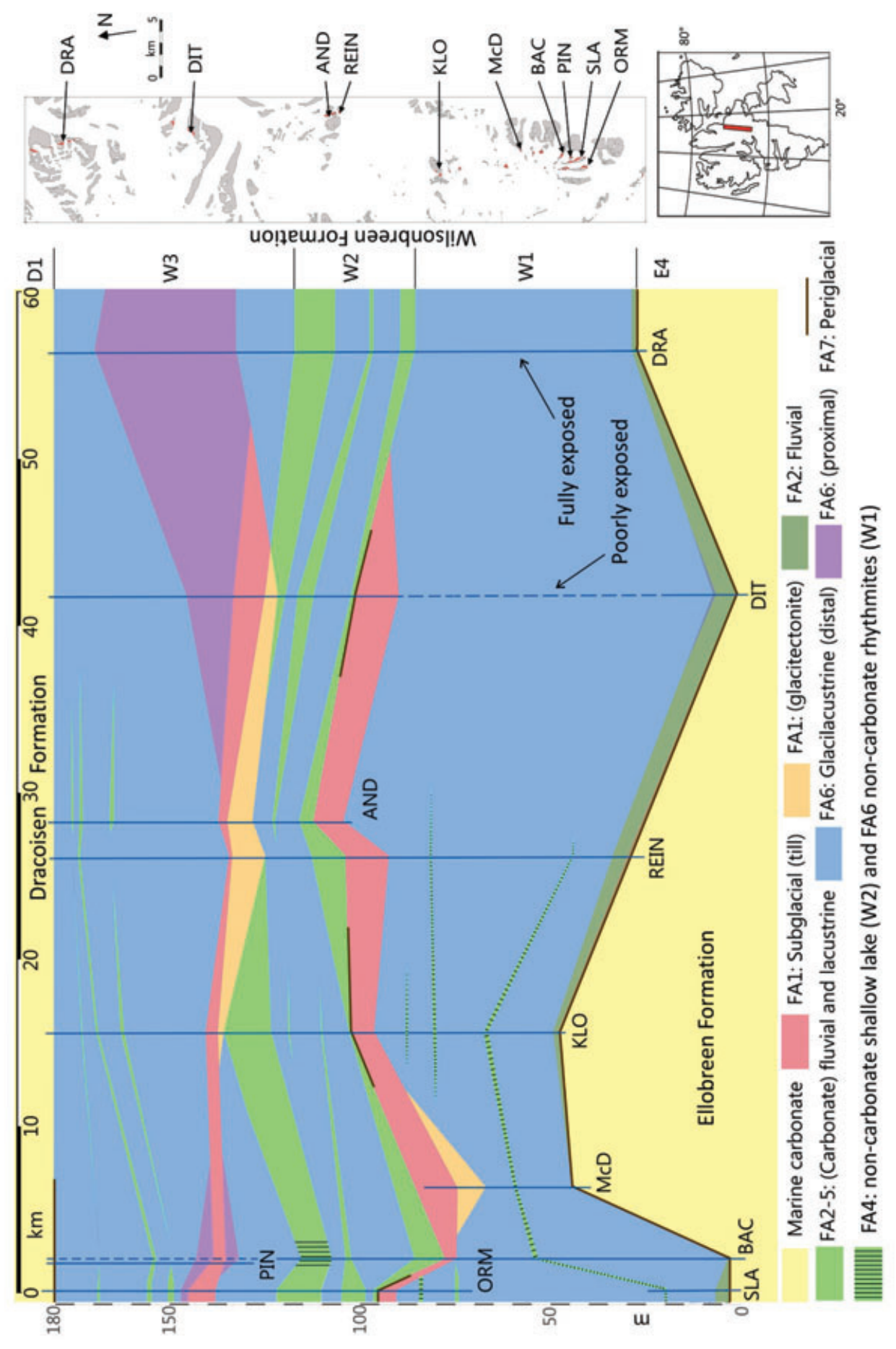

This article is protected by copyright. All rights reserved. 

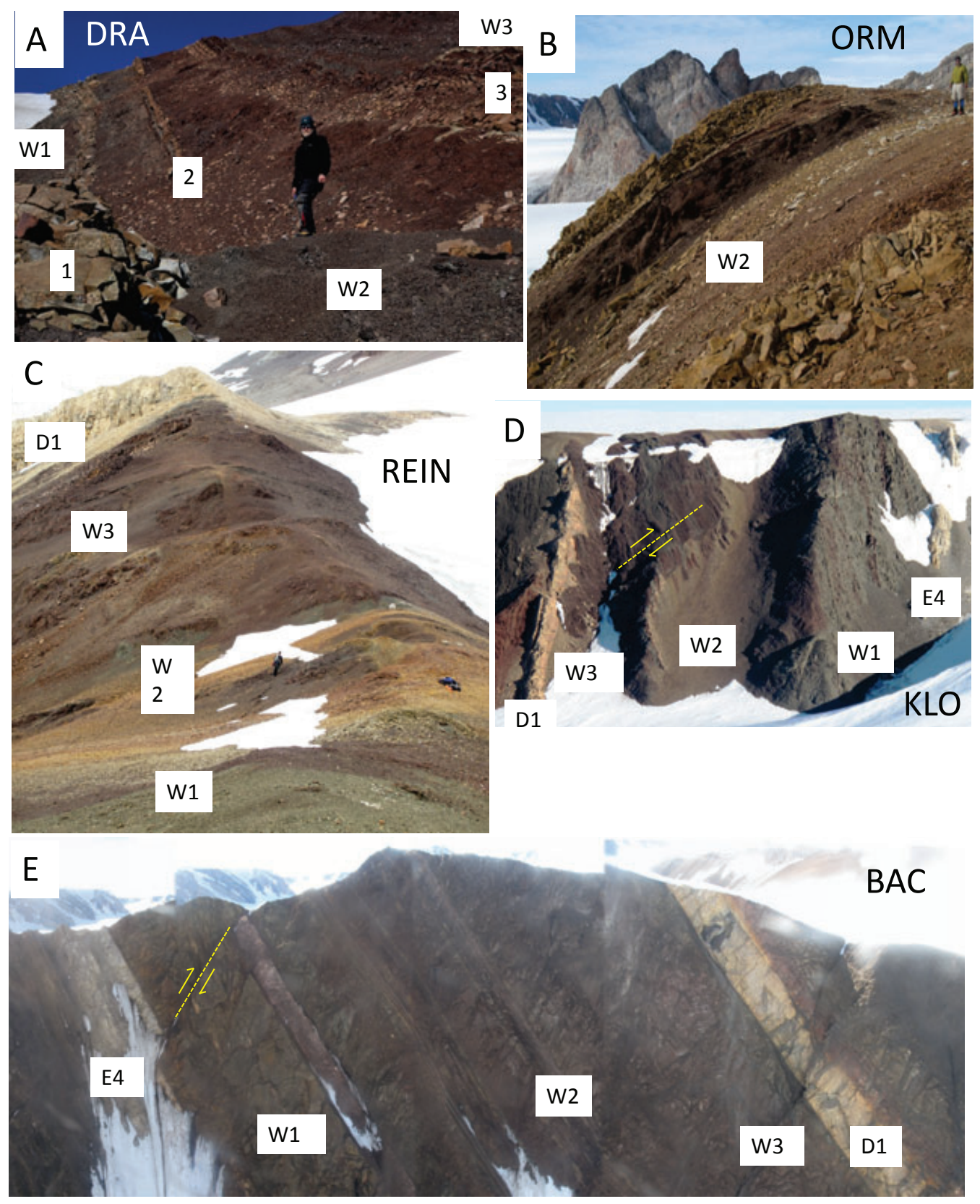

This article is protected by copyright. All rights reserved. 

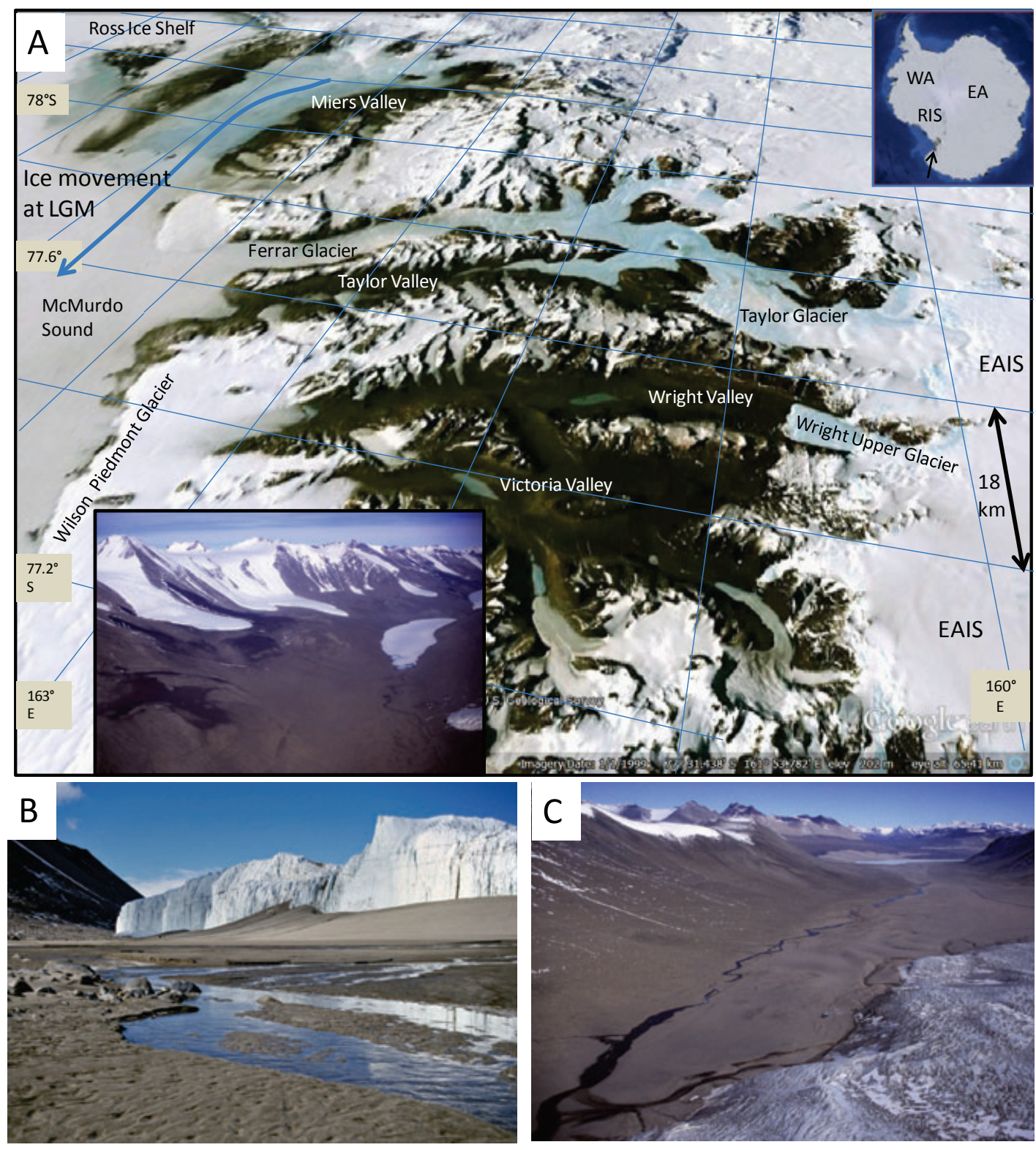

This article is protected by copyright. All rights reserved. 


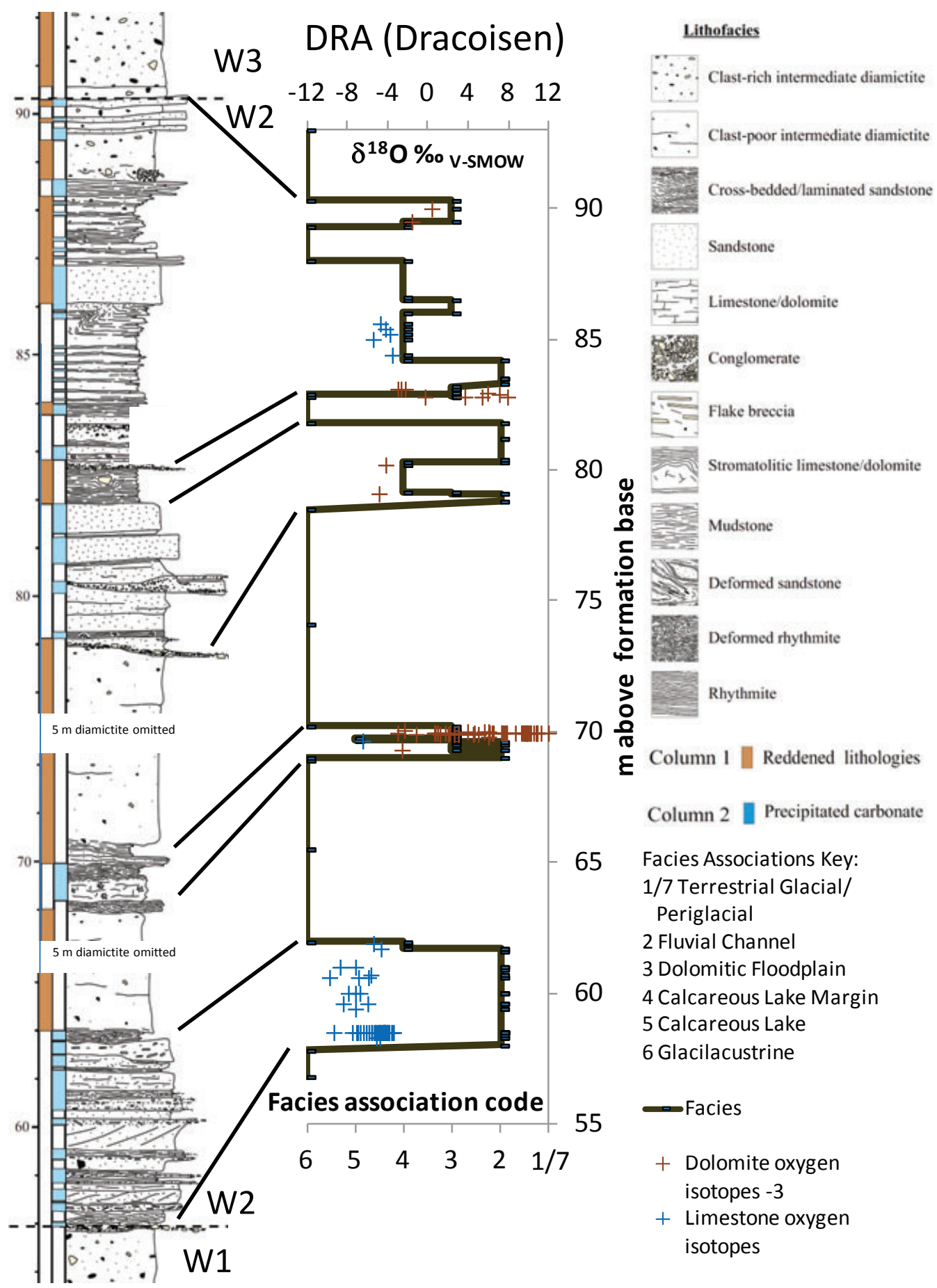

This article is protected by copyright. All rights reserved. 


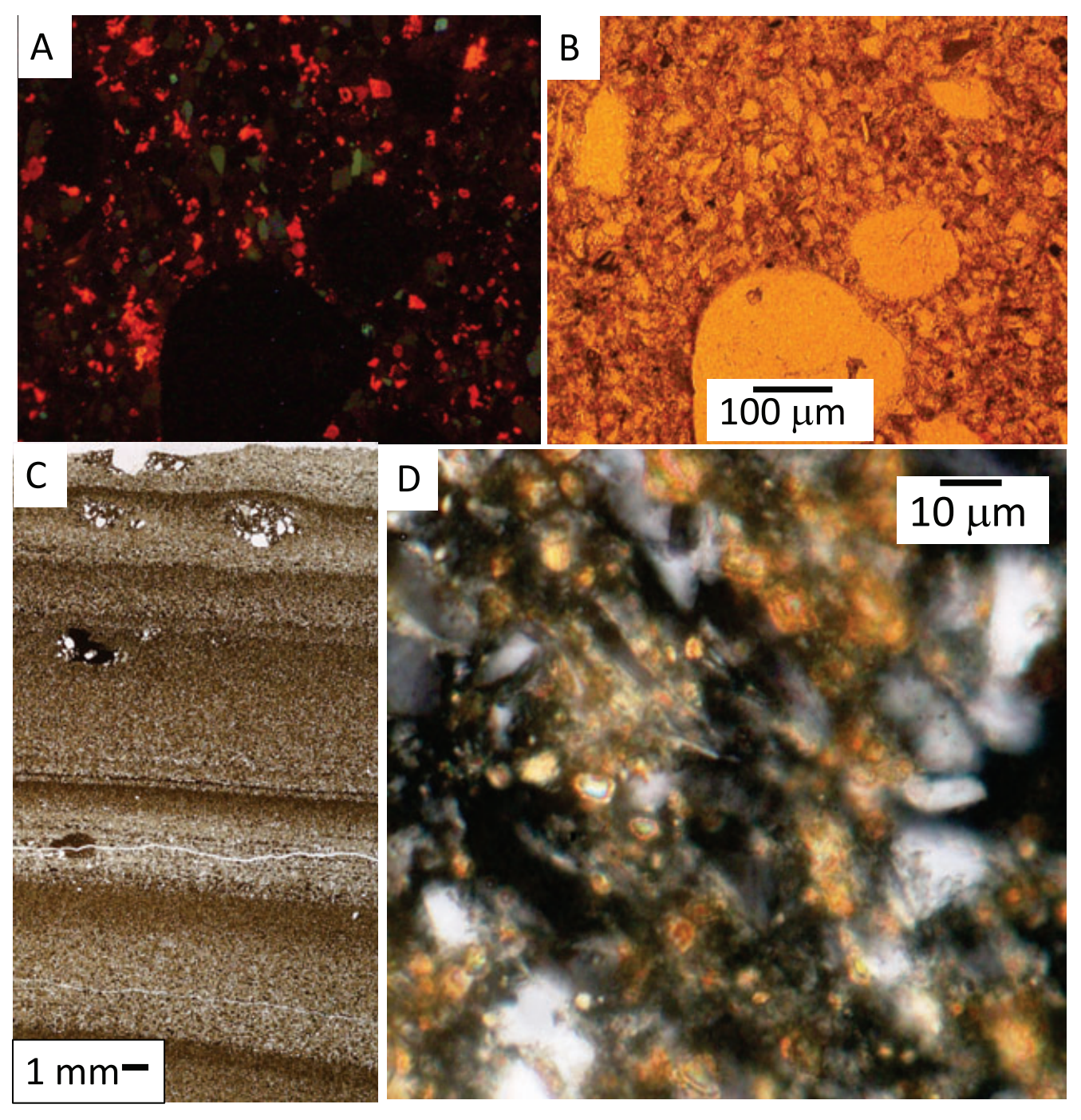

This article is protected by copyright. All rights reserved. 

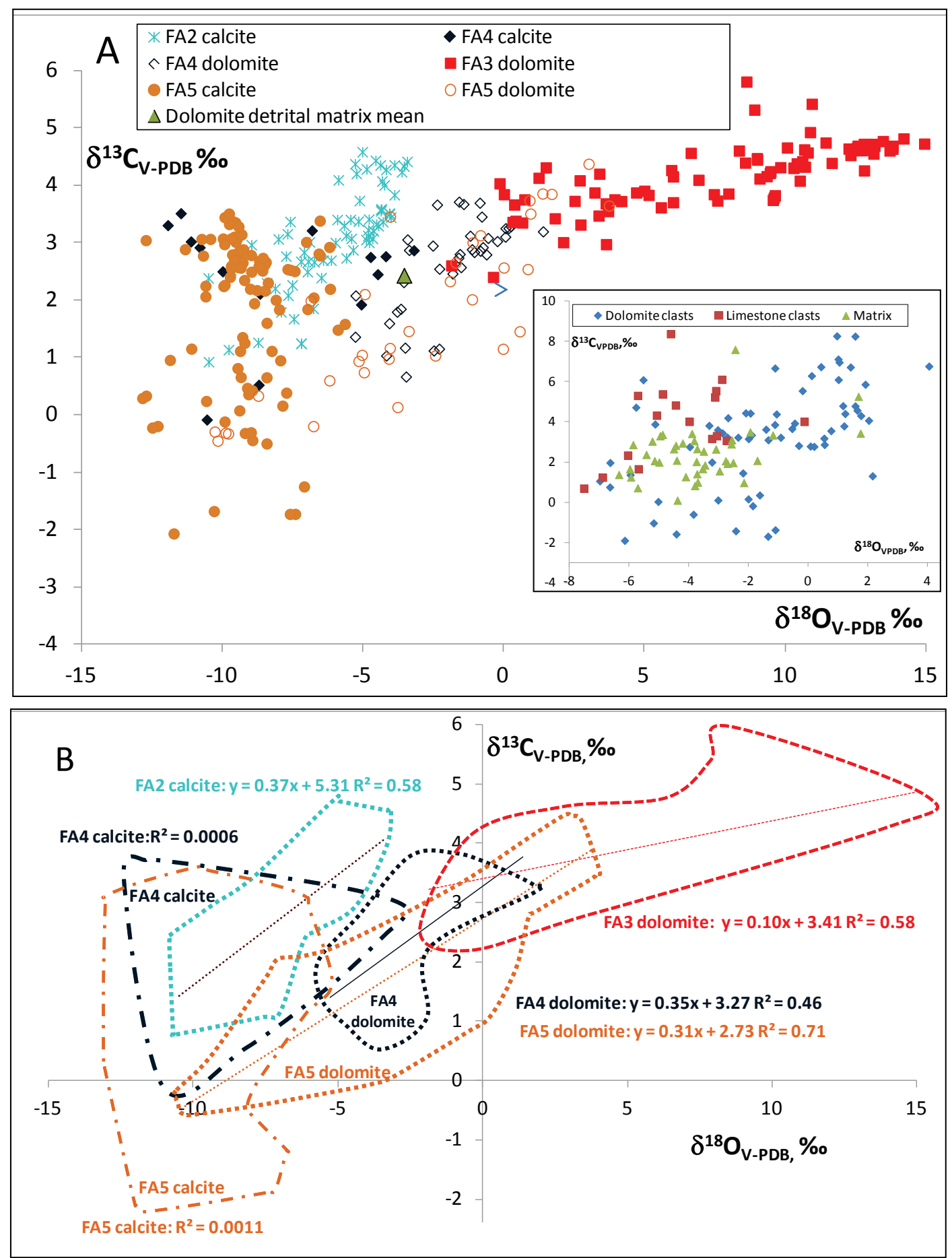

This article is protected by copyright. All rights reserved. 


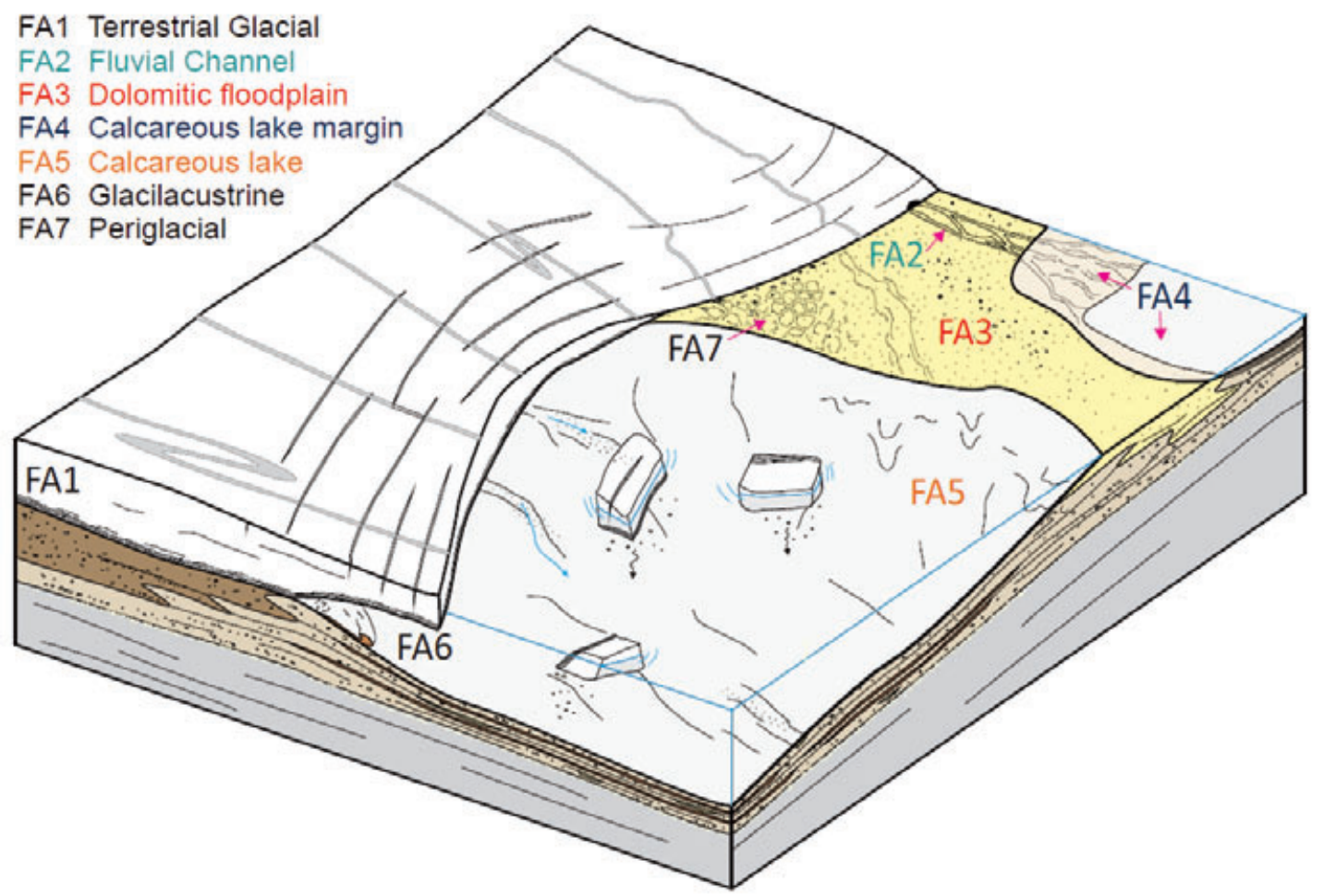

This article is protected by copyright. All rights reserved. 

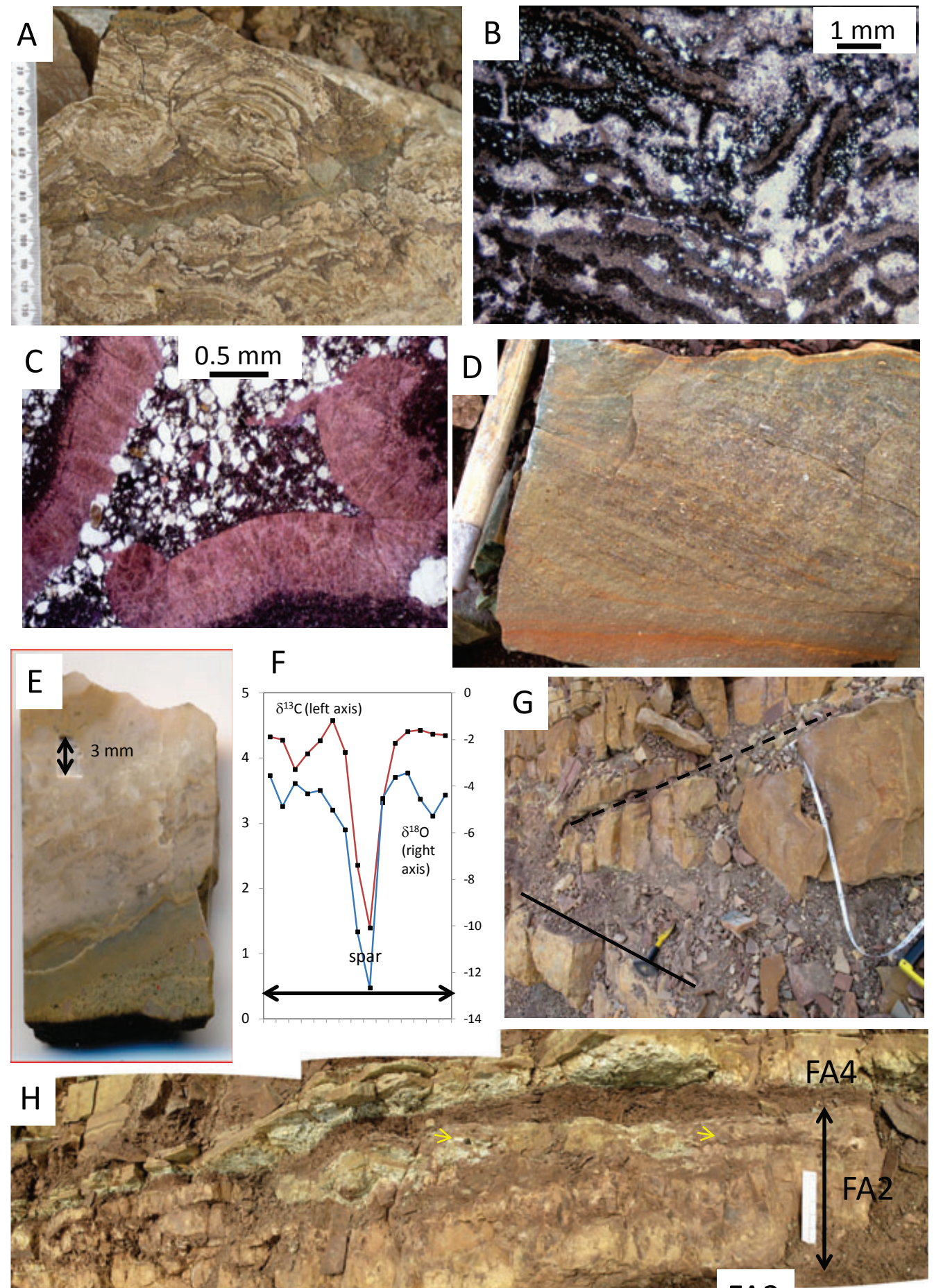

FA3

This article is protected by copyright. All rights reserved. 

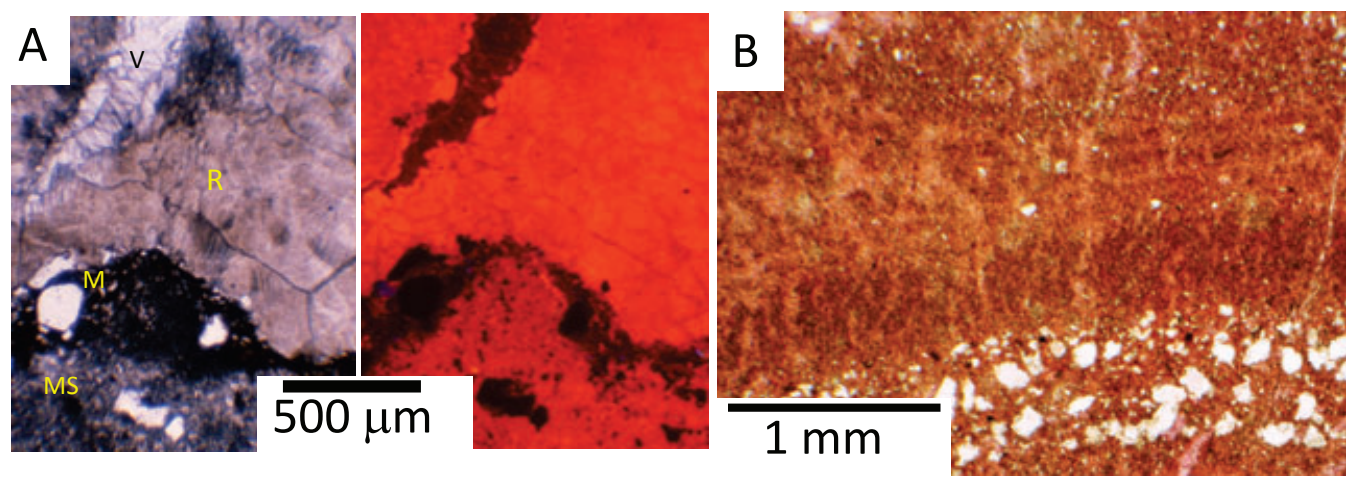

This article is protected by copyright. All rights reserved. 

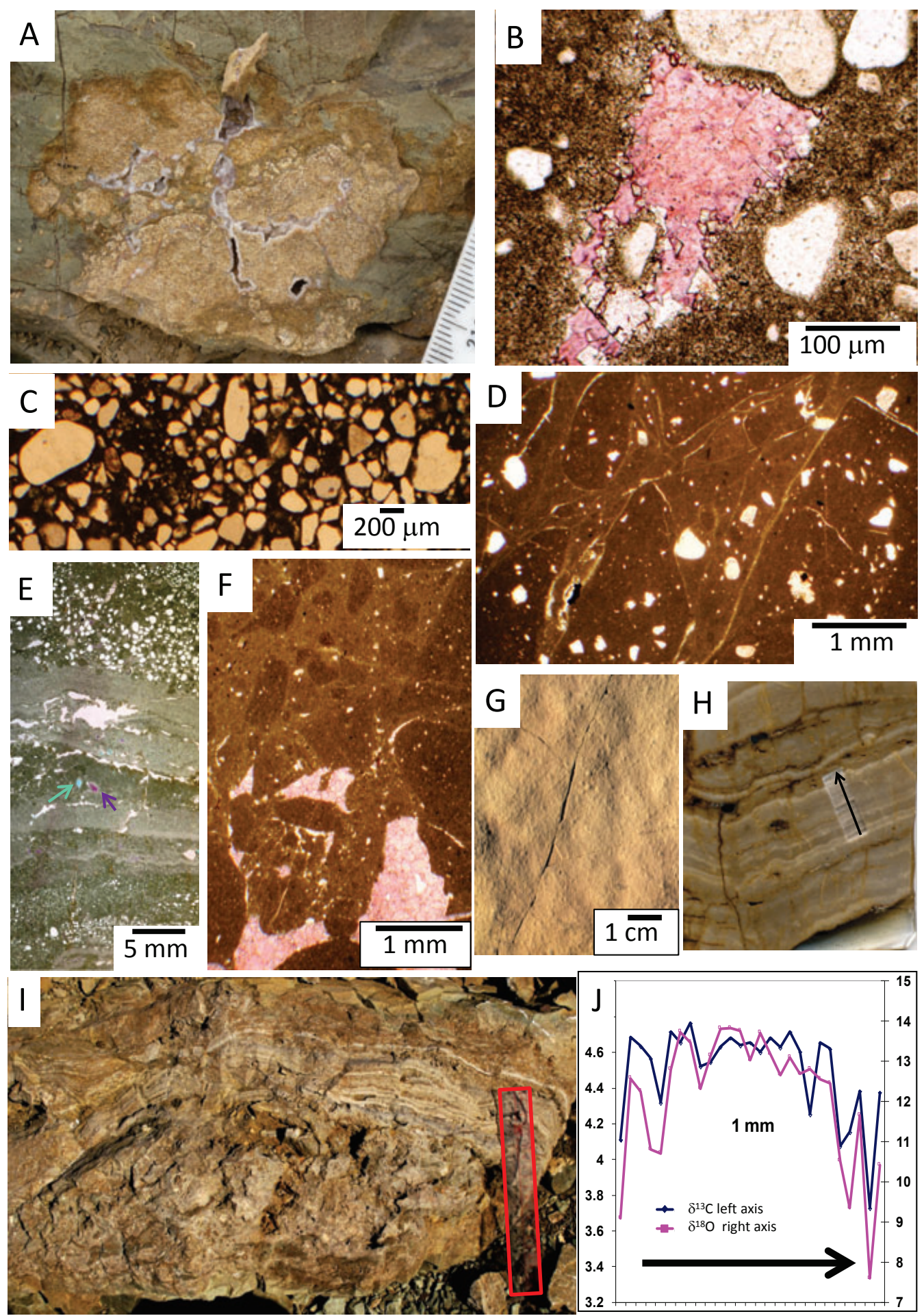

This article is protected by copyright. All rights reserved. 

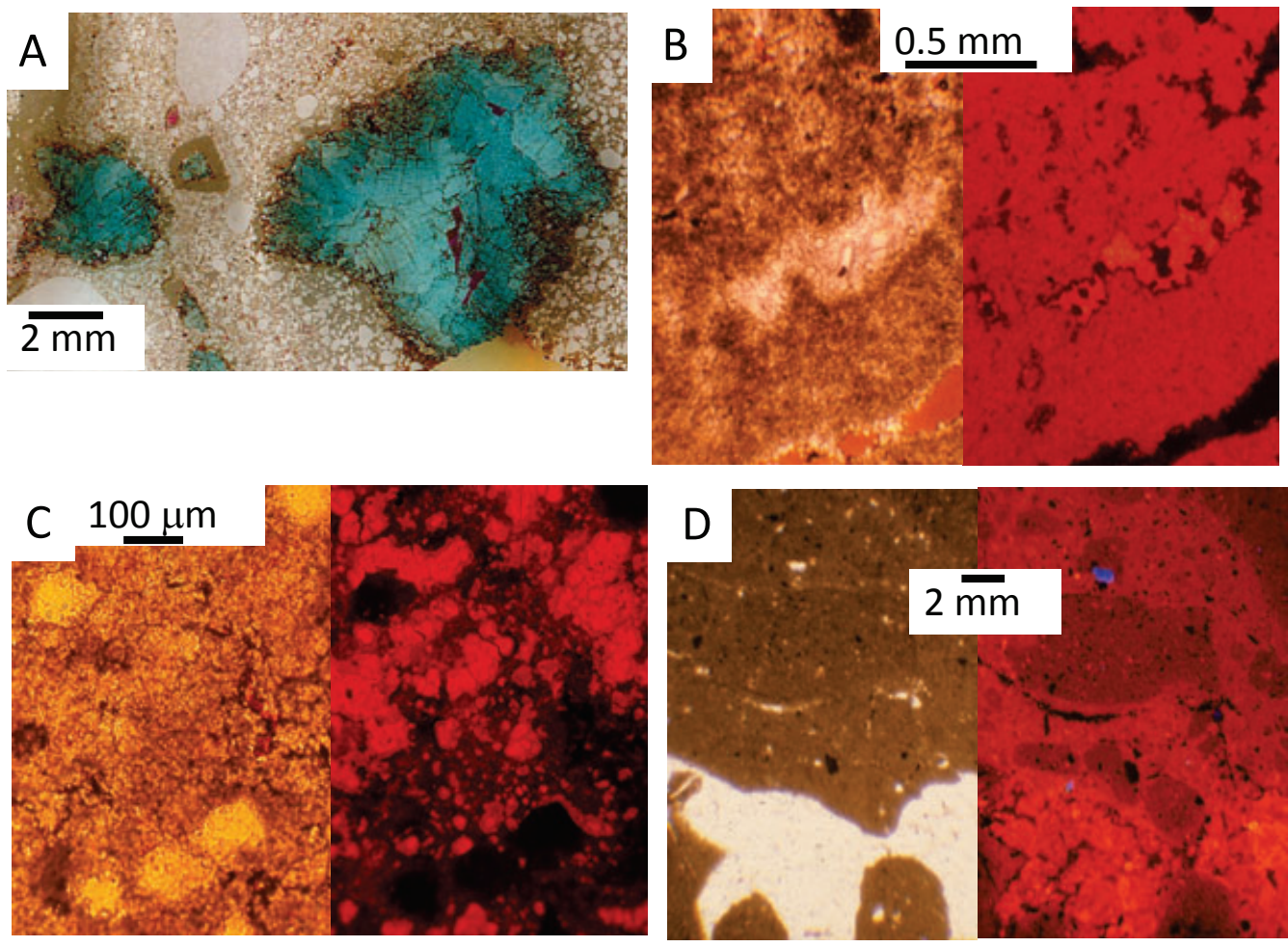

This article is protected by copyright. All rights reserved. 


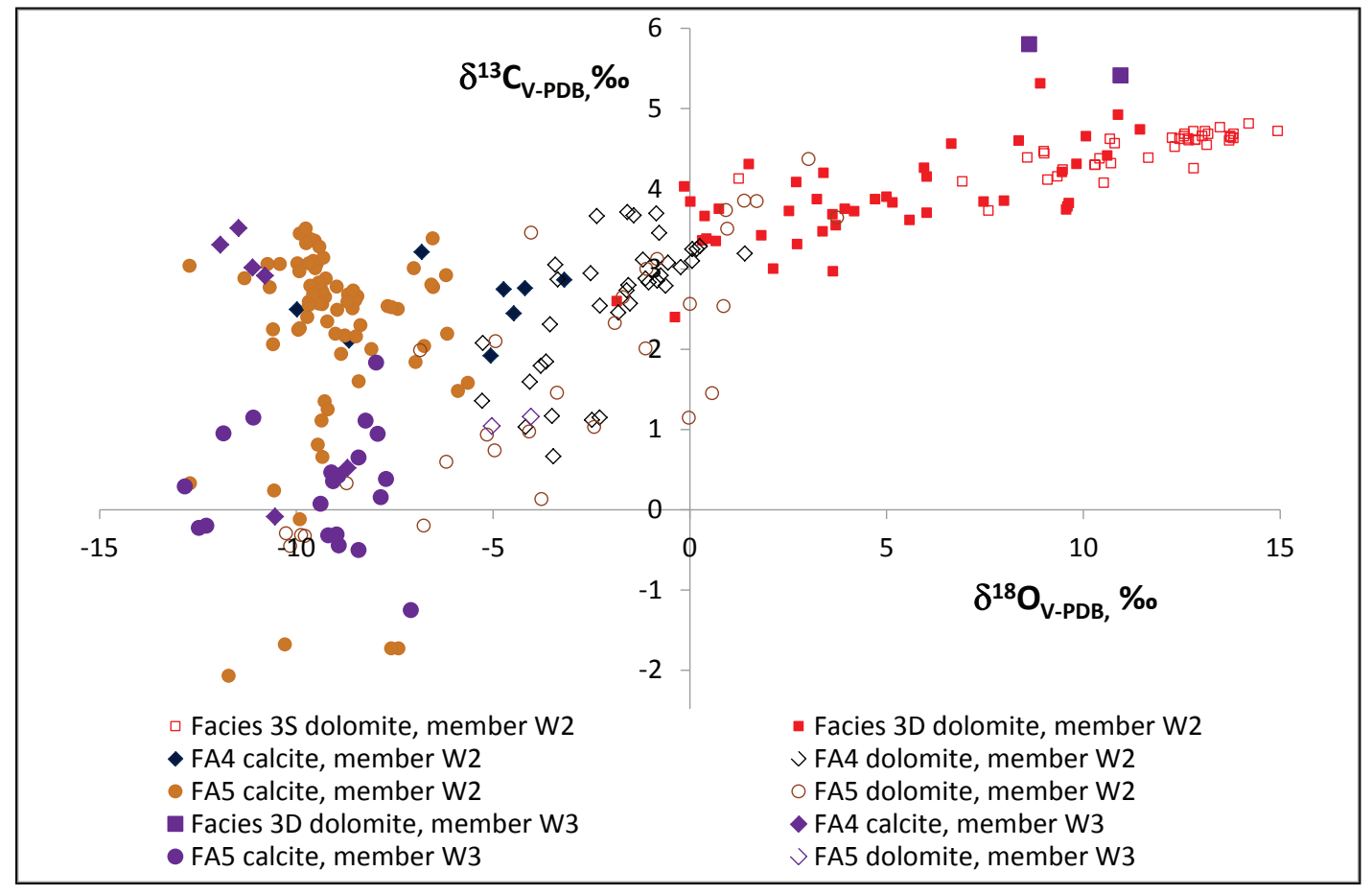

This article is protected by copyright. All rights reserved. 

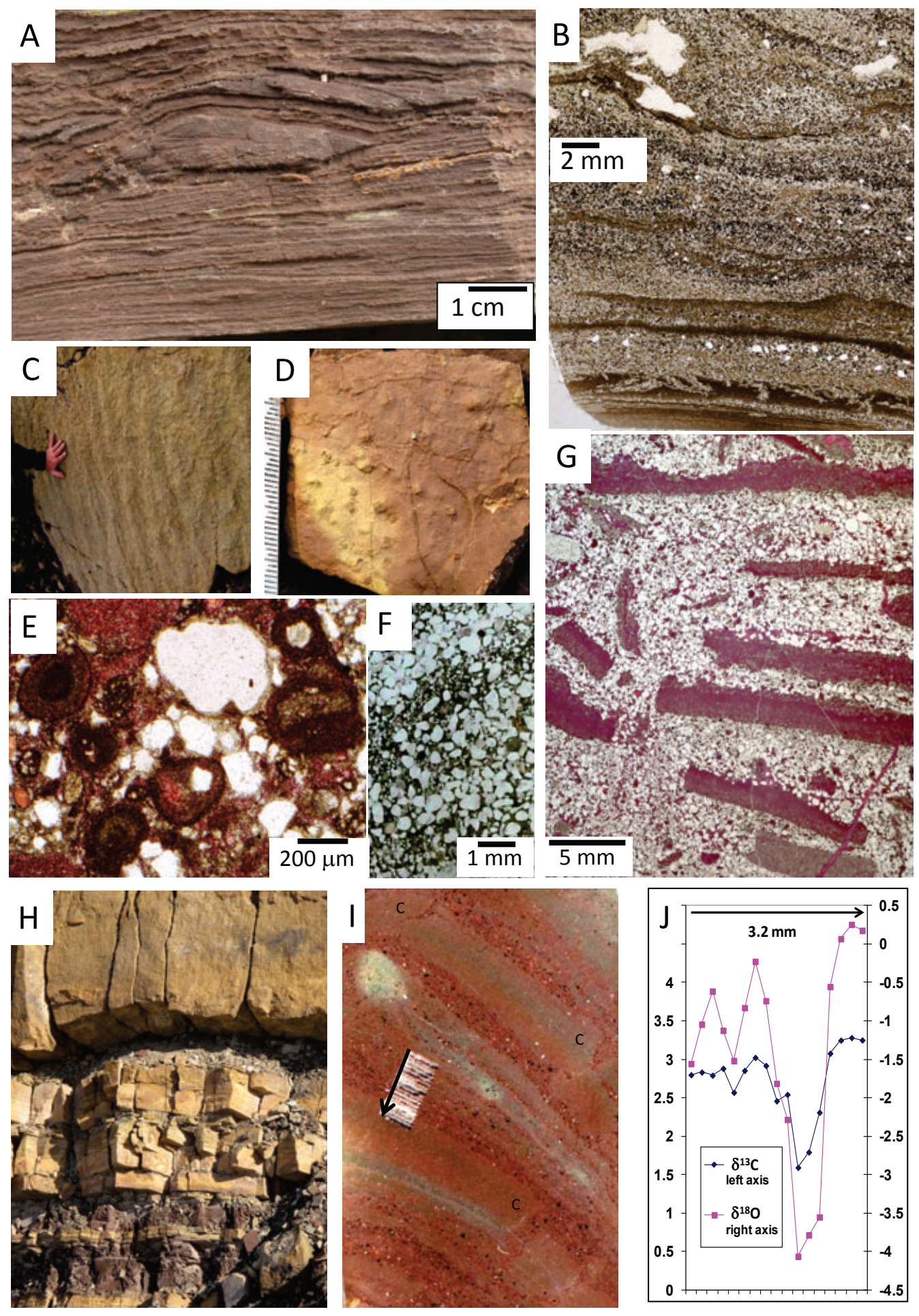

This article is protected by copyright. All rights reserved. 


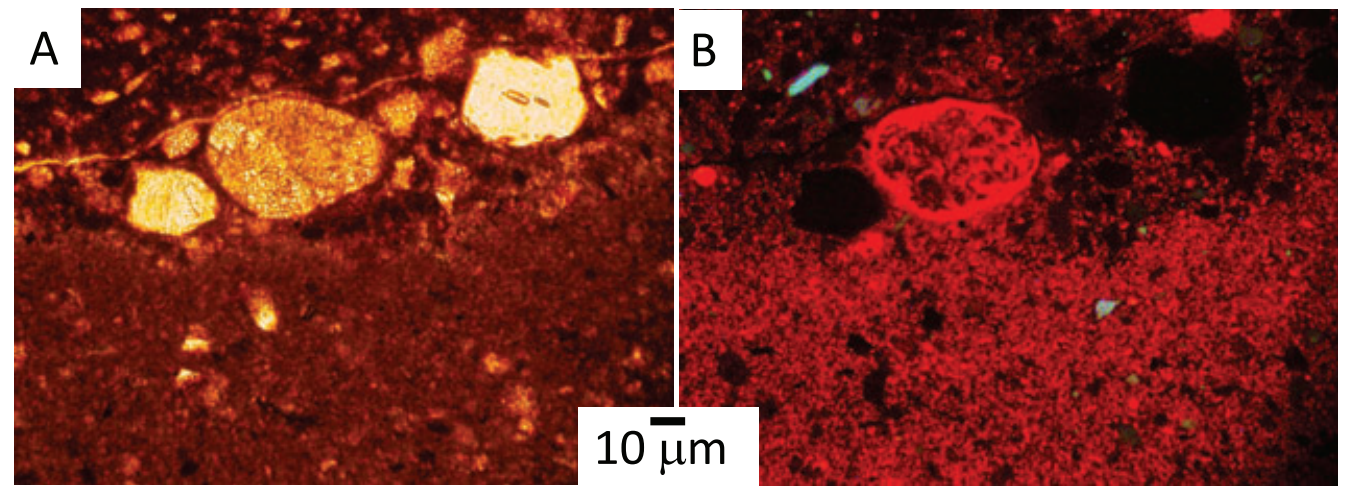

This article is protected by copyright. All rights reserved. 


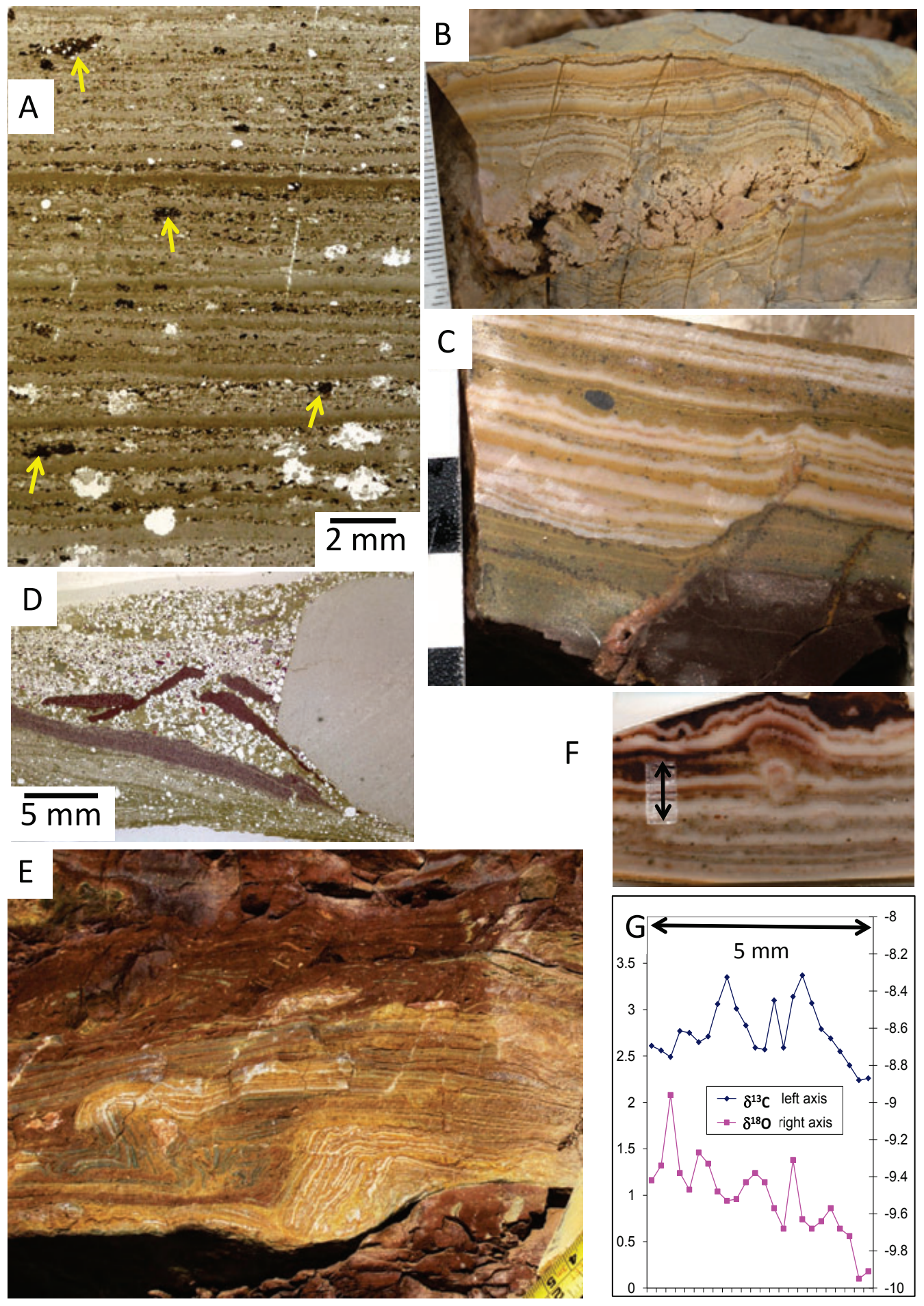

This article is protected by copyright. All rights reserved. 


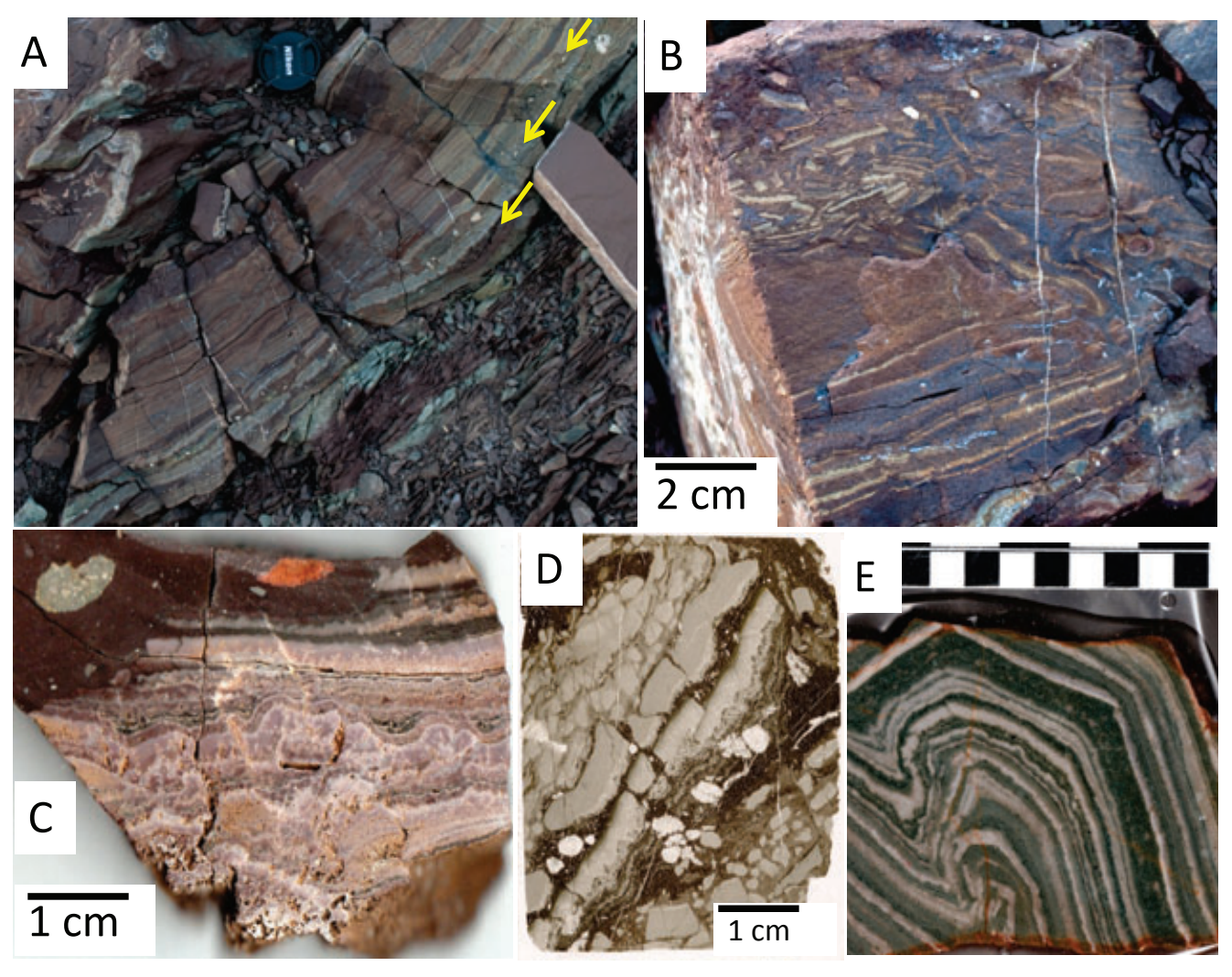

This article is protected by copyright. All rights reserved. 

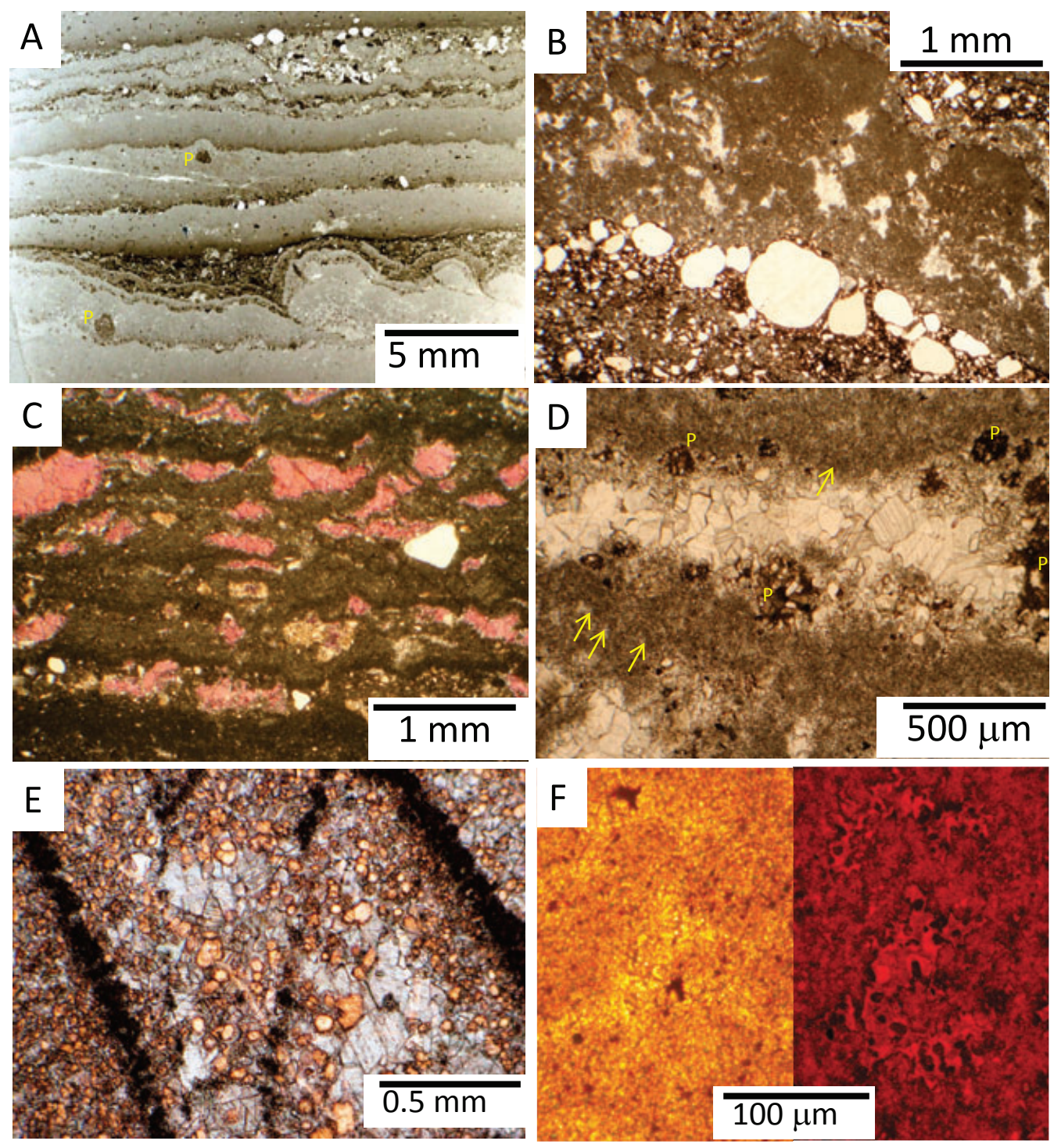

This article is protected by copyright. All rights reserved. 

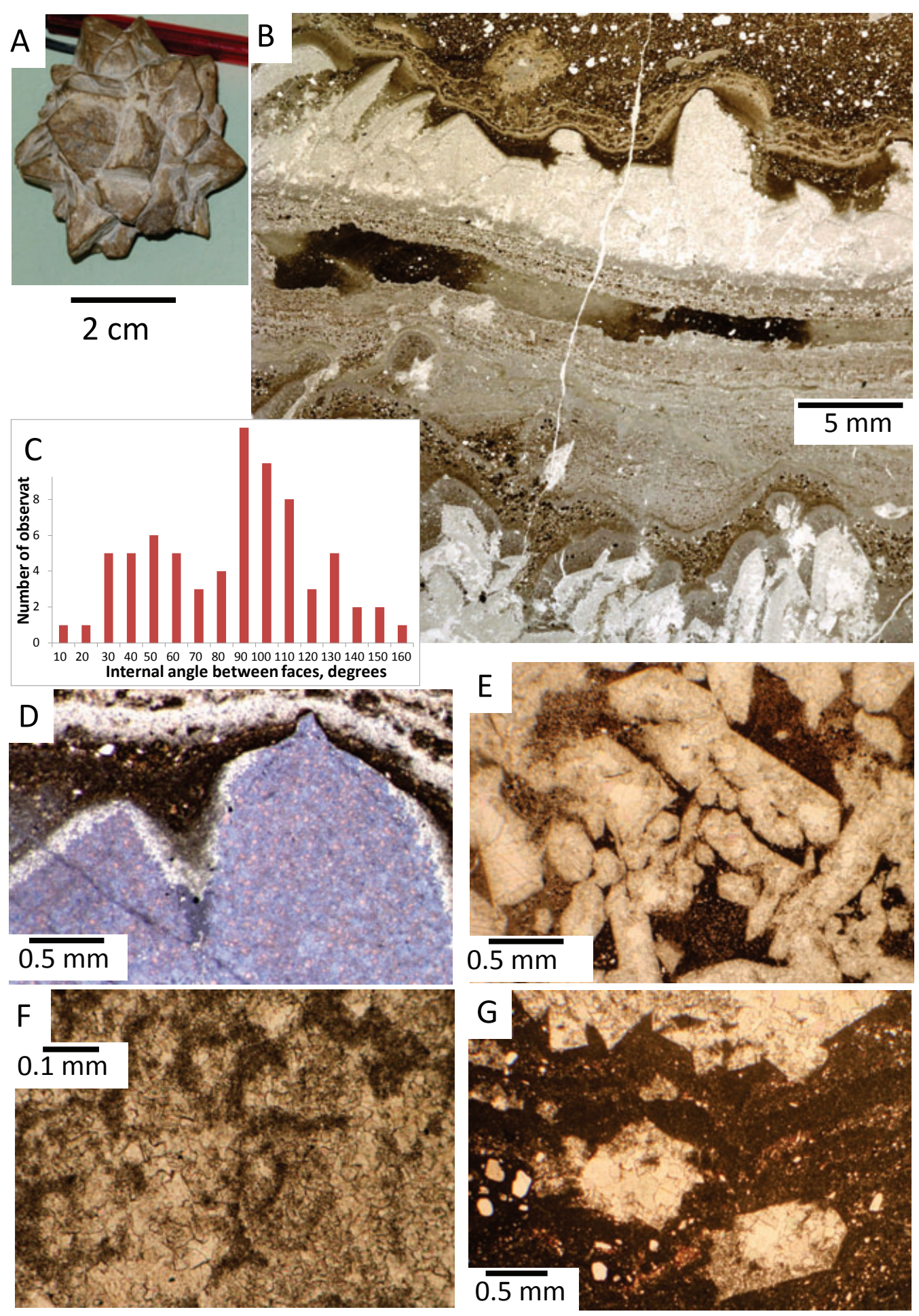

This article is protected by copyright. All rights reserved. 


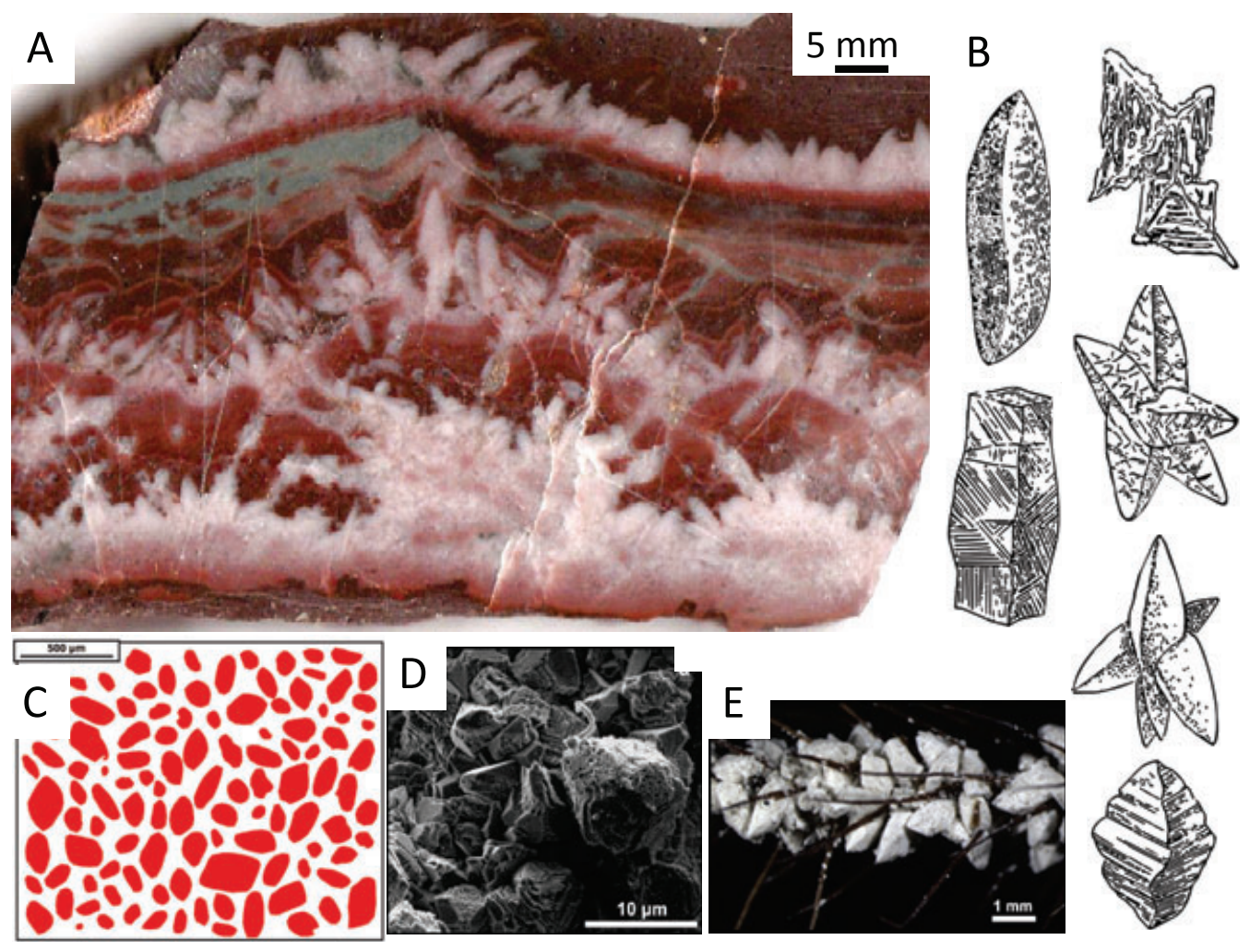

This article is protected by copyright. All rights reserved. 


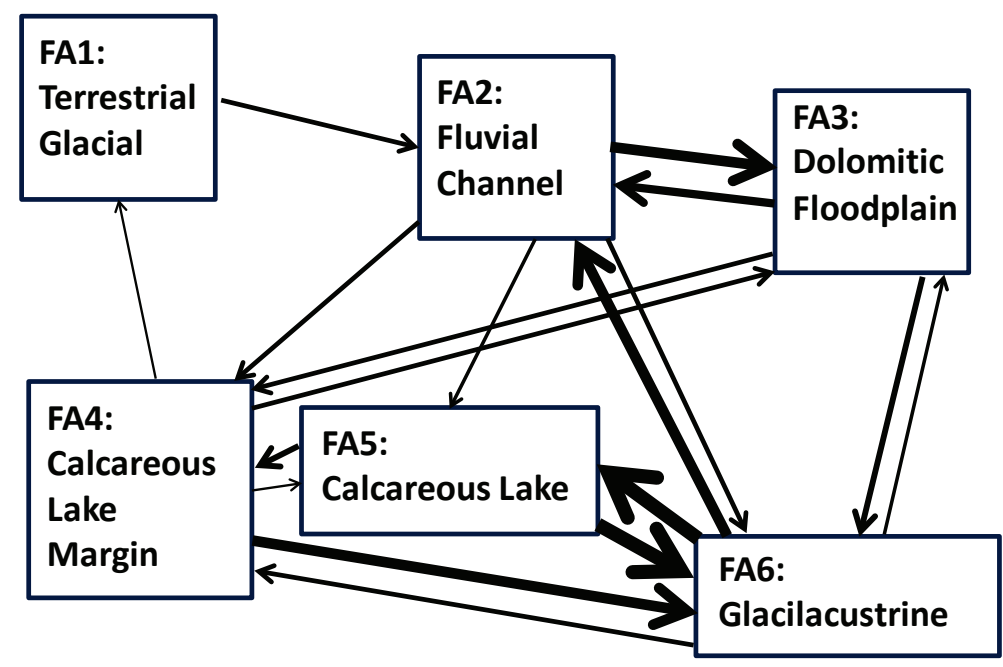

This article is protected by copyright. All rights reserved. 


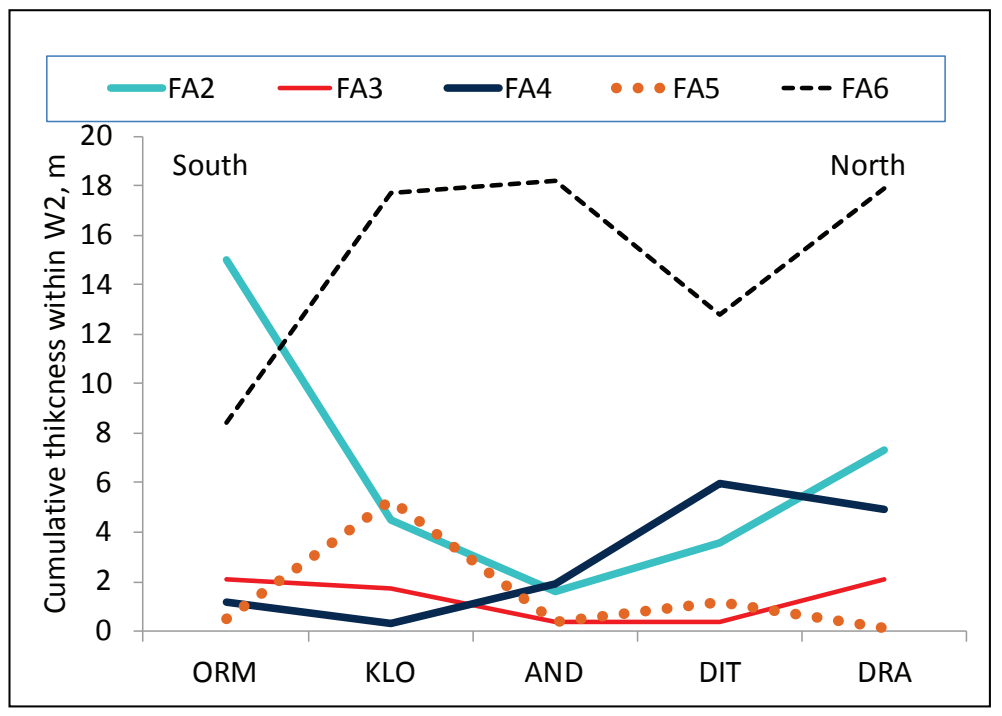

This article is protected by copyright. All rights reserved. 


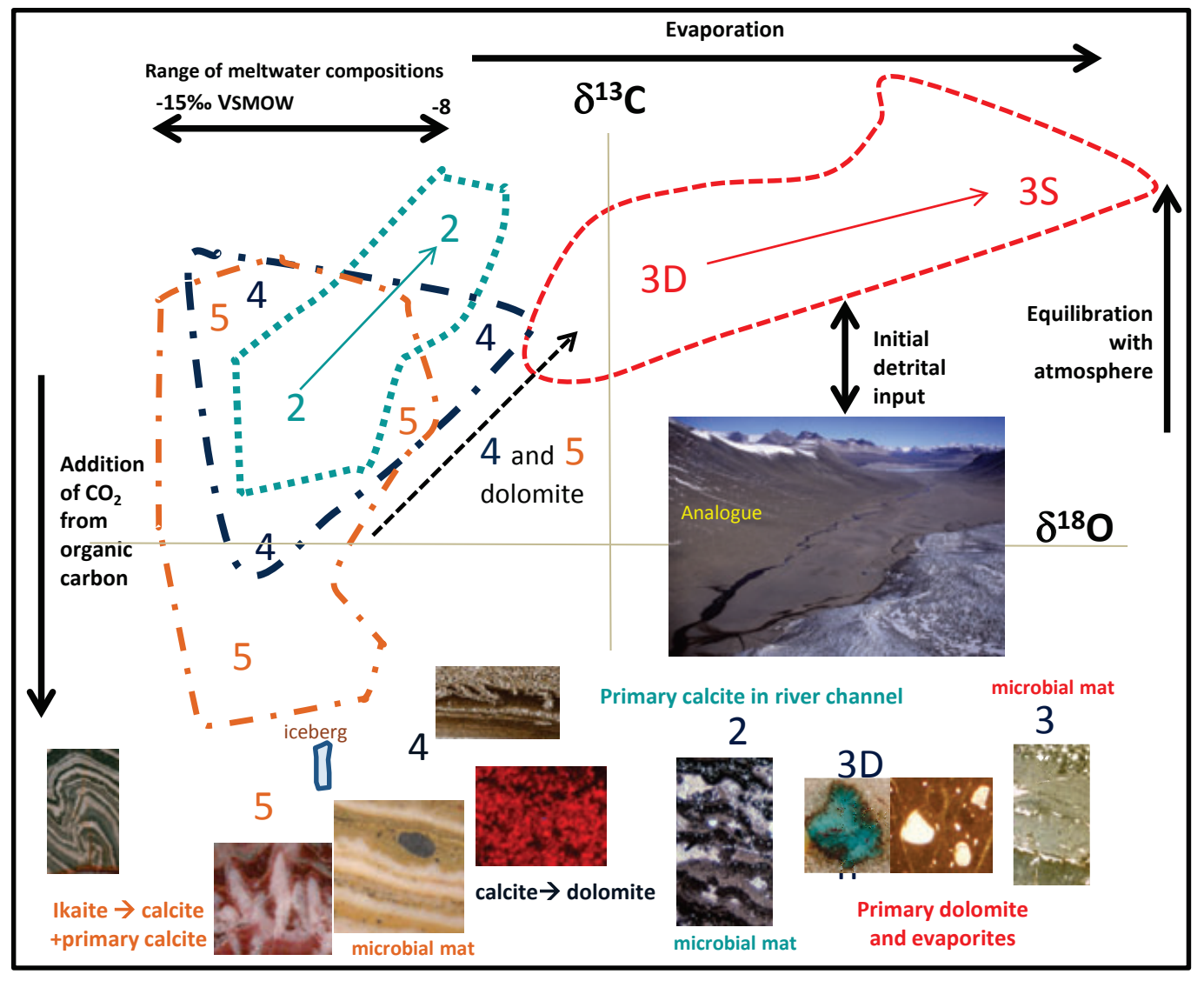

This article is protected by copyright. All rights reserved. 